UNIVERSIDADE DE SÃO PAULO

FACULDADE DE FILOSOFIA, LETRAS E CIÊNCIAS HUMANAS

DEPARTAMENTO DE LETRAS CLÁSSICAS E VERNÁCULAS

PROGRAMA DE PÓS-GRADUAÇÃO EM LITERATURA PORTUGUESA

\title{
Um viajante em busca do essencial - A personagem entre a aparência e a essência
}

\author{
PATRICIA CONCEIÇÃO SILVA SANTOS
}

São Paulo

2008 


\title{
UNIVERSIDADE DE SÃO PAULO
}

FACULDADE DE FILOSOFIA, LETRAS E CIÊNCIAS HUMANAS

DEPARTAMENTO DE LETRAS CLÁSSICAS E VERNÁCULAS

PROGRAMA DE PÓS-GRADUAÇÃO EM LITERATURA PORTUGUESA

\section{Um viajante em busca do essencial - A personagem entre a aparência e a essência}

\author{
PATRICIA CONCEIÇÃO SILVA SANTOS
}

Tese apresentada ao Programa de Pós-

Graduação em Literatura Portuguesa, do

Departamento de Letras Clássicas e Vernáculas

da Faculdade de Filosofia, Letras e Ciências

Humanas da Universidade de São Paulo para

obtenção do título de Doutor em Letras.

Orientadora: Prof ${ }^{\mathrm{a}}$. Dra ${ }^{\mathrm{a}}$. Raquel de Sousa Ribeiro

São Paulo 


\section{AGRADECIMENTOS}

À Prof ${ }^{\mathrm{a}} \operatorname{Dr}^{\mathrm{a}}$. Raquel de Sousa Ribeiro, pela orientação e paciência.

À Prof ${ }^{\mathrm{a}} \operatorname{Dr}^{\mathrm{a}}$ Maria Helena F. Peixoto, minha interlocutora.

Aos Professores Doutores Beatriz Berrini e Fernando Segolin, pelas conversas proveitosas.

A José Saramago, pela escritura desta e de suas outras obras.

Ao meu pai (in memoriam) e à minha mãe, pelo apoio, e a todos os demais integrantes da minha família, pela compreensão.

Ao Programa de Literatura Portuguesa, pelos cursos oferecidos.

Aos funcionários da Pós-Graduação de Literatura Portuguesa, pela boa qualidade do atendimento.

Ao Programa Bolsa-Mestrado, pela Bolsa que me foi concedida.

Ao setor de informática da FFLCH, pelo apoio digital.

E a todos os nomes, que, indiretamente, deram condição de existência a este trabalho de pesquisa. 


\section{RESUMO}

Este trabalho busca examinar as relações de poder alegorizadas no romance Todos os Nomes, de José Saramago. Usando principalmente as teorias de Mikhail Bakhtin e Michael Foucault sobre o processo de constituição do sujeito moderno (entendido, neste caso, como um sujeito que se reconhece como portador de uma identidade própria, ainda que, paradoxalmente, se saiba também integrante de um grupo social que o concebe e o solicita como um "corpo dócil e útil"), este trabalho enfoca desde a arquitetura "panóptica" do espaço impessoal da Conservatória do Registro Civil, que mantém seus funcionários numa rígida e produtiva disciplina de trabalho sob o olhar vigilante do Conservador, até os comportamentos transgressores do Sr. José em seu processo que investiga a identidade da mulher desconhecida, passando pelo exame dos recursos carnavalescos que visam a desmascarar o poder instituído. A análise visa provar que existe uma intrínseca e inextricável relação entre o poder instituído (representado pela figura do conservador) e o sujeito que se submete a esse poder (representado, no romance, pela figura do Sr. José), de tal modo que o desenvolvimento da autoconsciência do sujeito e a sua libertação em relação à condição anterior de assujeitamento (na terminologia de Foucault) acarretam, necessariamente, mudanças nas diferentes microesferas de poder (também com base no pensamento de Foucault).

Palavras-chave: Oficial, Oficioso, autoconsciência, relações de poder, carnavalização. 


\section{ABSTRACT}

This work aims to analyse the power relationships allegorized in the novel Todos os Nomes (All the Names), written by the Portuguese writer José Saramago. Using mainly Bakhtin's and Foucault's theories about the process of modern subject constitution (that who recognizes himself as owning his own single identity, though he also recognizes the use social forces and power instances make of him as "a teachable and ductible body"), this work focuses on the social and functional "panoptical "architecture of the register office ("Conservatória"), whick keeps the workers in a rigid but productive discipline, under the watching eyes of the "Manager". But it also focuses on "Sr. José's transgressive attitudes along his investigatory route to discover the unknown woman's identity. And it also investigates the unmasking of the hegemonic power by means of the Bakhtinian carnavalization procedures which have the power to relativize the official conceptions of reality. This analysis aims to prove that there's an inextricable link between the institutional forces and the subject who's submitted to this power, so that the development of one's consciousness causes a direct consequence on the hegemonic power forces, with subtle changes in the power relationships.

Keywords: signifying order, non-signifying order, self-consciousness, power relationships, carnivalization 


\section{SUMÁRIO}

Introdução

p.07

1. O protagonista entre a reprodução e a desconstrução do poder instituído

p.16

2. A figura do Sr. José entre o não ser e o ser

p.37

3. O herói (e seu duplo) em busca de si mesmo e do outro

p.53

3.1. A autoconsciência do Sr. José

p.53

3.2. A autoconsciência do conservador

p.75

4. O desmascaramento do poder burocrático

p.83

4.1. O narrador irônico

p.88

4.2. O carnaval na Conservatória

p.99

5. Conclusão

p.114

6. Bibliografia

p.119 


\section{Introdução}

O foco de interesse deste trabalho é a obra de José Saramago. Tanto em razão do seu instigante estilo narrativo quanto em razão da temática que ele aborda, que contempla temas atuais, buscando promover reflexões que abrangem desde os problemas histórico-políticos de Portugal até outros mais universais, como, por exemplo, as relações de poder que se estabelecem nas sociedades disciplinares, entre as quais a sociedade burocrática, que determina o modo de organização social e mental dos séculos mais recentes.

A identificação entre o modelo de organização das relações de trabalho na Conservatória, a preocupação com a (questionável) polarização entre vida e morte, o eixo da narrativa girando em torno de um funcionário honesto e trabalhador, que, de uma hora para outra, se defronta com a necessidade íntima, mas imperiosa, de dar um rosto a alguém que até então era apenas um nome, tudo isso motivou, nesta etapa do nosso percurso acadêmico, a eleição de Todos os nomes como objeto desta tese de Doutorado.

O romance está incluso no rol das obras da fase saramaguiana denominada por alguns críticos de universal, pois retrata situações temáticas que podem acontecer em qualquer outro lugar e não necessariamente em Portugal. A época em que se passa a história também não está demarcada de forma precisa. Aliás, não se deve estranhar este procedimento, pois esta forma de lidar com a narrativa, em que elementos da atualidade se misturam aos do passado, parece fazer parte do estilo do autor. Portanto, em alguns momentos do romance, chega-se a crer que o tempo abordado é o da atualidade, levando-se em conta algumas afirmações, como a do conservador ao dirigir-se aos seus funcionários numa reunião, mencionando a falta de recursos tecnológicos na 
Conservatória, ou mesmo a parte em que são narrados os números absurdos de túmulos no cemitério. Porém, ao mesmo tempo, percebe-se a presença de formas de comportamento tradicionais que lembram uma época remota: a falta de informatização e o excesso de cerimônia em torno da figura do conservador estão entre elas.

O procedimento do escritor em não demarcar o espaço e o tempo nas suas últimas obras e, mais especificamente em Todos os nomes, pode ser visto como um dos traços pós-modernos da obra. De acordo com as idéias defendidas por Linda Hutcheon em sua obra Poética do pós-modernismo, faz parte do pensamento pós-moderno a falta de contornos nítidos para a realidade, pois é próprio deste pensamento compreendê-la de forma relativa. As idéias expostas neste trabalho de Doutorado seguem o mesmo caminho das da teórica canadense e, ao mesmo tempo, nesta tese tem-se consciência de que não se deve, em momento algum, tentar rotular a obra de Saramago de pósmoderna.

O romance Todos os nomes foi publicado pela primeira vez em 1997, um ano antes de o escritor ser contemplado com o Prêmio Nobel de Literatura, distinção que o inscreveu na história da Literatura como o primeiro escritor em língua portuguesa a ser honrado com esse prêmio.

Em seu Diário de Lanzarote, Saramago relata que a motivação para escrever este romance adveio da sua curiosidade em desvendar a inexistência do registro de óbito do seu irmão, Francisco de Sousa, na Conservatória de Golegã. Assim ele se refere ao episódio: “(...) Tal como estão as coisas agora, é como se eu tivesse um irmão imortal (...).” (1999, p. 226). Diante deste impasse, o romancista resolveu sair à procura do documento, que somente reapareceu após algum tempo. 
Apesar disso, o autor afirma, numa das declarações dadas na época de lançamento de Todos os nomes, que esta história não tem nada a ver com o enredo da obra, porém, sem esse acontecimento, o livro não teria sido escrito.

A ação do romance gira em torno da busca empreendida pelo protagonista de nome José por uma mulher desconhecida, de 36 anos, pessoa tímida, professora de matemática da mesma escola onde havia estudado, e que termina por suicidar-se por um motivo aparentemente inexplicável. Ou seja, o pretexto que moverá a busca do protagonista prende-se à procura por uma mulher anônima, mas, no decorrer da narrativa, percebe-se que a sua trajetória vai além de alcançar o seu objeto desejado: empreende uma grande busca descompromissada de ganhos materiais pelo próprio prazer de vivenciar o processo de busca e, quem sabe, encontrar um sentido para sua existência.

Quanto ao título da obra, embora se espere que, no romance, as personagens sejam todas nomeadas, ironicamente nenhuma delas o é, à exceção do protagonista. Ainda assim, seu nome, com conotações mais simbólicas do que individualizantes, também não identifica nem singulariza a personagem.

O nome "José", único atributo identificador da essência da personagem, tem conotações múltiplas, como é comum nas obras de Saramago, mas o tom irônico que as percorre imprime uma possibilidade "carnavalesca" de interpretação, na medida em que evoca, de um lado, o trabalho artesanal, de carpintaria, de busca de construção da própria identidade, típico da figura do pai de Jesus, e, de outro, parece aludir ao trabalhador comum, anônimo.

Ainda em relação ao nome do protagonista, Saramago declara tratar-se apenas de um nome próprio bastante comum. Na época da publicação da obra, a crítica chegou a afirmar a influência que o poema E agora José?, de Carlos Drummond de Andrade, 
teria exercido sobre o autor na elaboração da obra. Em resposta a esta hipótese, Saramago confirma conhecer o texto, porém não admite ter partido dele para escrever Todos os nomes.

$\mathrm{O}$ escritor, numa de suas declarações, justifica-se quanto à escolha do título da obra, afirmando que estava sobrevoando a cidade de Brasília, quando lhe veio à mente a expressão "Todos os nomes", e que, no início da sua escritura, ele havia pensado em atribuir nome a todas as personagens, com exceção do Sr. José, mas depois, no momento em que escrevia a narrativa, mudou de idéia.

Num trecho de entrevista concedida à revista Bravo!, José Saramago dá a sua explicação para a escolha final:

(...) Os nomes deixaram de ter significado. O que tem significado são os números. $\mathrm{O}$ número da conta bancária, o número do bilhete de identidade, $\mathrm{o}$ número do passaporte. Aos bancos não interessa nada saber como nos chamamos. Interessa saber que número temos. É a perda dos nomes, que eu acho que está em processo, essa espécie de inutilidade...Nem sequer é perda do nome: é inutilidade do nome (...) O número é que conta. Que efeito isso vai ter no futuro? Não sei, continuo a não saber. (1999, 21, p. 69)

De todo modo, a escolha do nome para este romance somente fará sentido para o leitor à medida que ele avançar na narrativa e perceber a função do título no seu contexto geral. Tal como ocorre com o nome da personagem, este título também carrega uma conotação irônica, ou seja, também contém em seu bojo o seu contrário: percorre a narrativa a sutil constatação de que, nos dias de hoje, ninguém tem outro nome que não aquele que lhe é dado socialmente. Ou melhor, ninguém tem, efetivamente, um nome que sinta como genuinamente seu.

Em termos deste trabalho, seu objetivo está voltado para o estudo do percurso do protagonista desde que acha o verbete de uma mulher desconhecida enquanto está procurando informações sobre pessoas famosas nos arquivos da Conservatória. A tese defendida é a de que se trata de um percurso de natureza iniciática, que envolve a busca 
da autoconsciência por meio da interação dialógica com outras esferas sociais. Outro aspecto relevante está atrelado à hipótese aqui defendida de que existe uma intrínseca e inextricável relação entre o Poder instituído (representado pela figura do conservador) e o sujeito que se submete a esse poder (representado, no romance, pela figura do Sr. José), de tal modo que o desenvolvimento da autoconsciência do sujeito e a sua libertação em relação à condição anterior de assujeitamento acarretam, necessariamente, mudanças nas diferentes microesferas de poder (com base no pensamento de Foucault). Deve-se deixar claro que, apesar das diferenças de nomenclatura, as idéias de Foucault e Bakhtin sobre as relações de poder são convergentes e, neste sentido, a eleição dos dois pensadores para trazer o respaldo teórico a este trabalho não afetará os resultados esperados.

A presença de espaços institucionalizados por onde a personagem transita em busca de informações sobre o "seu objeto de desejo" (a mulher desconhecida), como a Conservatória, a escola e o cemitério, por exemplo, marca a impessoalidade com que os seres humanos são identificados e tratados na sociedade contemporânea. O suicídio da mulher desconhecida, uma professora de Matemática (ou seja, aquela que "professa" a crença no pensamento cartesiano, para o qual a lógica matemática é a única que resiste à prova da dúvida) também aponta para o fracasso do modelo organizacional da sociedade e do pensamento contemporâneos do Ocidente.

A intenção da análise crítico-interpretativa deste trabalho é mostrar que a saída para este conflito de natureza social e existencial não está em outro espaço, mas sim em outra forma de relações. Não há, portanto, que buscar a construção de outro espaço, mas, sim, buscar a construção de outra forma de relações sociais, baseadas estas no conceito bakhtiniano de linguagem compreendida como relação. 
Assim, o enfoque da obra Todos os nomes prende-se essencialmente à análise da trajetória do protagonista em busca de sua autoconsciência e a significação existencial desta busca. Somente quando o Sr. José resolve reagir ao isolamento em que vivia e parte para uma aventura em busca de outra pessoa, ele irá atribuindo significações a sua vida. O Sr. José é movido pelo desejo de encontrar a mulher desconhecida, que também pode ser vista como o seu duplo, levando-se em conta as semelhanças entre as duas personagens e o quanto se sente identificado com ela. Prova disso é que ele aceita correr todos os riscos em troca de informações sobre a vida dela. Porém, apesar de não conseguir encontrá-la, ele irá passar por uma série de transformações, assim como provocará mudanças em seu meio de trabalho, ao influenciar o conservador a propor a dissolução das fronteiras entre o arquivo dos vivos e dos mortos.

A sustentação teórica principal deste trabalho será buscada no pensamento de Mikhail Bakhtin sobre a construção da personagem no romance polifônico (seguindo o modelo das personagens de Dostoiévski, único escritor que, segundo Bakhtin, desenvolveu o romance genuinamente polifônico). $\mathrm{Na}$ esteira do movimento interior das personagens dostoievskianas, procurar-se-á examinar o percurso do Sr. José, oscilante entre a aceitação e a rejeição das normas sociais estabelecidas, entre a revolta ou a resignação, mas retratando as transformações operadas na consciência do protagonista e reconhecidas nas suas diversas atitudes responsivas ao seu meio social.

Dado que o pensamento de Bakhtin constitui um sistema coeso, em que os conceitos das diferentes áreas se articulam harmonicamente, junto com os conceitos de polifonia, de autor e de autoria, de diálogo socrático, sátira menipéia, carnavalização, serão ainda utilizados os conceitos ligados ao tema da arquitetônica da respondibilidade, que contribuem para esclarecer melhor o processo dialógico de formação da autoconsciência. 
Além das obras de Bakhtin, as obras de Foucault, como Microfísica do poder e Vigiar e punir, também fornecerão subsídios para compreender como se organiza (e como funciona) a arquitetura de vigilância das sociedades disciplinares (especialmente a burocrática). A compreensão de Foucault de que o poder existe não como substância, mas como exercício, nas práticas sociais, permite verificar, em Todos os Nomes, como se constrói a personagem Sr. José enquanto "objeto dócil e útil" ao conservador e à instituição da Conservatória, e permite ver como ele, gradativamente, vai buscar constituir-se como sujeito portador de uma consciência da própria identidade, mobilizado pela força do desejo interior. Serão ainda utilizados como base teórica do primeiro capítulo alguns textos contidos na obra Sociologia da Burocracia, que contam com a colaboração do teórico Max Weber. Estes textos serão de grande auxílio na nossa análise sobre a significação da burocracia e de que forma ela constitui-se num sustentáculo para a sociedade contemporânea, não perdendo de vista a figura do protagonista em meio a tudo isso.

Este trabalho consta de quatro capítulos, cada um procurando enfocar uma etapa do percurso do protagonista. A fundamentação teórica está presente em todos eles, embasando cada etapa do desenvolvimento argumentativo, de modo que será possível observar o nosso movimento no sentido de relacionar a fundamentação teórica ao exame crítico-interpretativo da narrativa de Todos os nomes. A este respeito, as citações deste romance de Saramago, quando aparecerem no corpus da tese, serão referidas pela abreviatura TN.

Voltemos à descrição dos capítulos. O primeiro, intitulado "O protagonista entre a reprodução e a desconstrução do poder instituído", focaliza o ambiente burocrático representado pela Conservatória e as suas relações hierárquicas, procurando examinar, inclusive, a disposição espacial desse ambiente, que facilita o controle dos subordinados 
por meio do olhar vigilante. Nesta parte dar-se-á ênfase à análise do poder burocrático e do seu modo de sustentação.

No segundo capítulo, “A figura do Sr. José entre o não ser e o ser”, será examinada a figura do protagonista da obra na sua condição de integrante passivo e pacífico do corpo de funcionários da Conservatória, passando já, de algum modo, para a de um ser em busca de algo diferente, o que demanda, na obra, assumir riscos e passar a ser responsável por eles.

No terceiro, "O herói (e seu duplo) a busca de si mesmo e do outro", subdividido em dois tópicos ("A autoconsciência do Sr. José" e "A autoconsciência do conservador"), a intenção é acompanhar os movimentos do Sr. José e do conservador (seu duplo), procurando perseguir neles as quatro categorias propostas por Bakhtin.

Aqui será enfatizado o papel da busca na construção da autoconsciência do Sr. José e, conseqüentemente, do conservador. Como já foi dito, a fundamentação teórica, nesta etapa, ficará a cargo da obra de Bakhtin, Problemas da poética de Dostoiévski e terá em mente mostrar que tanto o Sr. José quanto o conservador desempenham um papel importante na mudança das formas de inter-relação pessoal na Conservatória. Sem o protagonismo do Sr. José e sem a cumplicidade do conservador, não seria possível a tomada de consciência das personagens e, conseqüentemente, a mudança radical na organização dos arquivos, com a abolição das fronteiras entre os arquivos dos vivos e dos mortos. Esta diluição das fronteiras pode, inclusive, ser vista como uma forma simbólica de se conservar a memória dos mortos. Ao que parece, é justamente nesta tentativa de preservação da memória que pode estar o resultado da grande viagem empreendida pelo protagonista em Todos os nomes.

Finalmente, no último capítulo, intitulado "O desmascaramento do poder burocrático", serão abordadas situações carnavalescas que envolvem tanto o 
protagonista quanto o poder burocrático como um todo, culminando na maior inversão carnavalesca da obra - a abolição de fronteiras entre os arquivos dos vivos e dos mortos. Estas situações carnavalescas em que o protagonista se vê envolvido fazem parte do processo da sua autoconsciência, assim como da do conservador. A partir do momento em que o Sr. José adota posturas consideradas bizarras pelo sistema burocrático, ele vai aprendendo a lidar com situações em que o conflito entre o oficial e o oficioso fica cada vez mais evidente.

Ao mesmo tempo, as inúmeras situações em que se mete no decorrer da sua busca, como, por exemplo, a invasão ao colégio em que a desconhecida havia estudado e lecionado, expressam este conflito. Isso ocorre porque, ao mesmo tempo que o protagonista representa o poder hierárquico (ao fazer parte do quadro funcional da Conservatória, ele adquire a aparência oficial perante a sociedade), ele desestrutura o poder quando deseja livrar-se da máscara de funcionário exemplar e assumir o seu lado humano e contraditório, que o fará sair em busca de um sentido para sua existência.

Ao longo do capítulo serão trabalhados os procedimentos que contribuem para esse desmascaramento do poder burocrático. No primeiro tópico, "o narrador irônico" e no segundo "o carnaval na Conservatória".

Terminada a descrição dos pressupostos e do conteúdo desta pesquisa, resta agora abrir as portas e ingressar nos espaços vestibulares e impessoais da Conservatória.

É o que será feito no primeiro capítulo. 


\title{
1. O protagonista entre a reprodução e a desconstrução do poder instituído
}

\begin{abstract}
“(...) porque é que um autor escreve este livro e mais aquele e outro ainda, quando entre esses livros não há possivelmente nem poderia haver, nenhuma separação, todos eles fluem no íntimo de uma infinita melodia, todos eles traduzem a busca de um mesmo equilíbrio, e em vez de muitos são, não podem deixar de ser, um único, um só, um todo indivisível?"
\end{abstract}

Augusto Abelaira ${ }^{1}$

Tal como em outras obras de José Saramago, em Todos os Nomes o sistema semiótico verbal e o pictórico se imbricam. Na verdade, o diálogo não se faz apenas entre a literatura e a pintura, pois, além desta, as demais artes espaciais também estão presentes, de um modo ou de outro, ao longo da narrativa. Assim, se, na abertura, a descrição da Conservatória lembra um quadro que o leitor estivesse a contemplar ou um filme que ele estivesse a assistir, é um desenho arquitetônico que ele tem diante de si no momento em que vai sendo introduzida a disposição dos cômodos e dos móveis desse mesmo espaço. Mais para o final, quando o protagonista decide visitar o túmulo da mulher desconhecida, o Cemitério surge, inicialmente, como um espelhamento do espaço da Conservatória e, num outro momento, faz lembrar a planta de uma cidade, evocando, portanto, os projetos urbanísticos das metrópoles contemporâneas. O mesmo convite à decodificação visual existe na apresentação dos outros espaços visitados pelo Sr. José: a escola, o apartamento da desconhecida, entre outros.

O procedimento adotado pelo narrador, comentado anteriormente, em enfatizar a descrição física do prédio da Conservatória, pode ser interpretado como uma estratégia para expressar a imponência do poder burocrático. Neste sentido percebe-se a sua

\footnotetext{
${ }^{1}$ ABELAIRA, A. Posfácio a Quatro paredes Nuas. Lisboa: Bertand, 1972. p.202
} 
preocupação em fazer uso do recurso pictórico, como forma de descrever a dominação do poder burocrático, representado pelo prédio da Conservatória em suas dimensões ciclópicas e pelo seu representante máximo, o conservador; sobre os funcionários. Ambos se sobrepõem aos indivíduos que nele trabalham. O primeiro capitulo de Todos os nomes é essencialmente descritivo e tem como preocupação mostrar a imponência da autoridade (através da descrição da arquitetura), assim como as relações hierárquicas ali mantidas.

Significativamente, os ambientes internos são, muitas vezes, labirínticos e escuros e, de certa forma, podem-se ler neles as angústias e tensões do ser humano, como se fossem quadros expressionistas. Um episódio ilustrativo é o da imersão do Sr. José no Arquivo dos Mortos, em busca do verbete que confirmará a morte da mulher desconhecida. Depois que, de novo por acaso, dá pela falta do verbete da desconhecida no Arquivo dos Vivos e tem a intuição de que ela está morta, ele decide pesquisar o Arquivo dos Mortos, munido apenas de uma lanterna de bolso e do "fio de Ariadne/cordel" que liga a mesa do conservador ao seu tornozelo. Seguem-se alguns fragmentos significativos desse episódio:

(...) O seu plano é começar a busca pelo espaço fundeiro, lá onde deverão estar o processo e o verbete da mulher desconhecida, ainda que, pelas razões já expostas, seja pouco provável que o arquivamento tenha sido efectuado de forma correcta. [...] Sabe que a dificuldade maior com que vai ter que lutar é a falta de luz. Tirando a secretária do chefe, por cima da qual continua a brilhar foscamente a lâmpada de sempre, a Conservatória está, toda ela, às escuras, mergulhada em densas trevas. (TN, 1997, p.168)

Também por causa da infração que está em vias de cometer (o narrador a chama de "crime", e o Sr. José tem consciência disso), ao natural temor que as trevas infundem, soma-se o tremor das mãos do infrator - afinal, está prestes a entrar em contato com as regiões e as práticas interditas: 
(...) Acender outras lâmpadas ao longo do edifício, mesmo desmaiadas como são, seria demasiado arriscado, um polícia cuidadoso ao fazer a ronda ao bairro, ou um bom cidadão, desses que se preocupam com a segurança da comunidade, poderiam perceber através das altas janelas a difusa claridade e dariam o alarme imediatamente. O Sr. José não terá portanto mais luz a valerlhe que o débil círculo luminoso que, ao ritmo dos passos, mas também por causa do tremor da mão que segura a lanterna, oscila à sua frente. (TN, p. 169)

E, enfim, o contato direto com a realidade tangível dos processos, verbetes e papéis empoeirados:

(...) Entretanto, coberto de pó, com pesados farrapos de teias de aranha pegados ao cabelo e aos ombros, o Sr. José alcançou enfim o espaço livre existente entre os últimos papéis arquivados e a parede do fundo, separados ainda por uns três metros e formando um corredor irregular, mais estreito em cada dia que passa, que une as duas paredes laterais. A escuridão, neste lugar, é absoluta. A fraca claridade exterior que ainda lograsse atravessar a camada de sujidade que cobre por dentro e por fora as frestas laterais, em particular as últimas de cada lado, que são as mais próximas, não consegue chegar até aqui por causa da acumulação vertical dos atados de documentos, que quase atingem o tecto. Quanto à parede do fundo, toda ela, é inexplicavelmente cega, isto é, não tem sequer um olho-de-boi que viesse ajudar agora a escassa luz da lanterna. (TN, p.171-172)

Aliás, não só neste caso, mas, em geral, os espaços físicos de Todos os Nomes costumam agir de maneira claustrofóbica sobre o protagonista, criando um efeito de opressão e enclausuramento, sensações que, de fato, dominam o indivíduo na sociedade burocrática dos nossos tempos. Além disso, a ausência de elementos temporais (ou mesmo a presença daqueles que remetem à ancestralidade, como a "poeira", "a sujidade", "os farrapos de teias de aranhas"), a linguagem densa e sinuosa, a presença de termos alusivos à mitologia (como os adjetivos "ciclópico" e "labiríntico", qualificativos do espaço da Conservatória) também contribuem para construir uma atmosfera arquetípica e, portanto, dotada da atemporalidade peculiar aos espaços que angustiam a alma humana em todas as épocas. 
Não apenas isso. A antropomorfização da Conservatória, com os veios de madeira da porta lembrando uma pele estriada pelo envelhecimento, suas paredes labirínticas contendo, de certo modo, toda a existência das pessoas (ainda que em formato de fichas) traduz, por alegoria, a inversão de valores da sociedade contemporânea, na medida em que acentua (também graças à monumentalidade e imponência do edifício e de seus interiores, o contraste em relação ao humano, reduzido, nos primeiros capítulos da obra, à minúscula habitação do Sr. José (como se esta estivesse em vias de ser engolida pela Conservatória) e à insignificância do protagonista.

Na verdade, o recurso estilístico usado por Saramago é similar ao utilizado pelos escritores naturalistas do século XIX, mas, neste caso, ele contribui para a melhor captação da dinâmica das relações entre as esferas representativas, tanto do poder instituído, quanto dos que a ele se subordinam. Em outras palavras, se, na literatura do século XIX, a antropomorfização do elemento espacial alegorizava a dominação do meio sobre o homem, em Todos os Nomes ela representa a anulação e conseqüente alienação do trabalhador (e, por extensão, do indivíduo como um todo) no modo de produção burocrático da sociedade contemporânea.

Ainda colaboram para a construção alegórica da idéia de "alienação/anulação" do homem pelo sistema um grande número de lexemas que aludem não apenas à automatização dos mecanismos de medição e aproveitamento do tempo nas relações de produção, mas também às relações interpessoais e à ação do tempo sobre as pessoas e as coisas, não escapando disso a ação da morte sobre a materialidade humana.

O contraste entre a Vida e a Morte (natural ou não) é evidentemente recorrente, funcionando o espaço da Conservatória ("hall de entrada" do cemitério e dos terrenos abertos onde ficam as diversas "alas" dos mortos) como um monstro, um Ciclope ou um 
Minotauro aprisionado no seu palácio. Não é à toa, então, a recorrência, na obra, das imagens míticas do fio da $\operatorname{Ariadne}^{2}$ (e as imagens grotescas que lhe fazem par: "o rústico e vulgar rolo de cordel comprado na drogaria" e "a lanterna de bolso com uma pilha nova", ambas explicitadas) e do "labirinto"..Para o desenvolvimento da relação entre o labirinto e a idéia da passagem do tempo, a referência à entrada de papéis, que envelhecem logo que chegam, contribui para evocar a precariedade da existência humana. Assim, eles representam, por relação metonímica, a essência da condição humana.

Na verdade, a descrição da Conservatória, que toma todo o primeiro capítulo do romance, permite traduzir esse espaço como espécie de simulacro da sociedade burocrática, em que os papéis, representados pelos verbetes, tanto das pessoas vivas quanto das mortas, exercem um papel preponderante, pois, é através deles que as pessoas ganham existência perante a sociedade. Assim, os verbetes seriam as certidões de nascimento, de casamento, de divórcio, de óbito, entre outras, as quais servem para atribuir às pessoas o status de cidadãos.

Tal leitura do elemento espacial conduz ao reconhecimento de uma relação entre Espaço e Homem, que, inicialmente, se pode compreender como dicotômica. No entanto é importante esclarecer que o termo "espaço" abarca, neste momento, os espaços de poder instituído, ou seja, espaços oficiais, imbuídos da sua correspondente autoridade; o termo "homem", por sua vez, abrange, neste caso, os indivíduos enquanto executores de funções na sociedade burocrática, como o conservador (ou o chefe), os subchefes, os auxiliares de escrita, a professora, o pastor, o enfermeiro etc. Nem mesmo

${ }^{2}$ É possível ler a figura de Ariadne como o pólo da "iluminação sublime" contrapondo-se à "iluminação rebaixada e desprotegida", representada pelo Sr. José. Um e outro vivem experiências de busca semelhantes, porém, no caso do Sr. José, a experiência mítica oscila entre o sagrado e o profano, sendo, portanto, uma paródia do mito de Ariadne.

${ }^{3}$ Quanto ao labirinto, imagem bastante recorrente nesta obra de Saramago, é possível estabelecer relações com a imagem do tempo que tudo devora, tal como o Minotauro devorava as sete moças e sete rapazes que lhe eram entregues no espaço do Labirinto como tributo pela morte do filho do rei Minos.(cf. GAMA KURY, Adriano. Dicionário de Mitologia Grega e Romana. Rio de Janeiro, Zahar, 1998.) 
o protagonista, único portador de uma "precária identidade", constituída pelo nome José, escapa a esse estado que o reduz ao anonimato ou, na terminologia marxista, à condição de integrante da classe proletária.

A concepção de poder que se pode observar neste romance de Saramago parece enquadrar-se no pensamento de Michel Foucault. Segundo Foucault, o poder em si mesmo não existe. $\mathrm{O}$ que, de fato, existe "são micro-relações de poder", que desembocam em "micropráticas de poder", existentes tanto no campo político quanto na vida cotidiana. Outro dado importante acerca da concepção de poder em Foucault é que o poder circula. Diz o autor em Microfisica do poder:

Quero dizer o seguinte: a idéia de que existe, em um determinado lugar, ou emanando de um determinado ponto, algo que é um poder, me parece baseada em uma análise enganosa e que, em todo caso, não dá conta de um número considerável de fenômenos. Na realidade, o poder é um feixe de relações mais ou menos organizado, mais ou menos piramidalizado, mais ou menos coordenado. (...) (FOUCAULT, 1979, p. 121)

Ora, esses dados permitem compreender as relações espaciais e interpessoais que permeiam a trajetória investigativa do Sr. José como representações alegóricas das "micro-relações de poder" que ele vai vivenciando à medida que se envolve em seu processo de conquista da autoconsciência. Em termos mais concretos, é possível ver, ao longo da narrativa, uma relação que, a princípio, era de subalternidade entre o Sr. José e o Conservador, desenvolvendo-se em uma cadeia progressiva de outras relações, por meio das quais o protagonista vai deixando a condição de "assujeitamento" para, gradativamente, passar a reconhecer-se como sujeito. Na verdade, o leitor depara-se com um jogo em que a aparência parece sobrepor-se a essência. Porém esta sobreposição também constitui uma representação momentânea, que ocorre logo no 
início do romance, pois que, aos poucos, vai apresentando uma reversão na dinâmica desse mesmo jogo.

A noção de "assujeitamento", na teoria de Foucault (que está bastante evidente nas construções alegóricas de Todos os Nomes), liga-se ao modo como se processa a constituição do sujeito moderno, por meio de mecanismos de poder que o submetem e o reprimem e o tornam um "objeto dócil e útil", mas que, simultaneamente, por meio da resistência que os acompanha, estimulam a busca da autoconsciência e o levam a tornarse um "sujeito preso à consciência de uma identidade própria" (FONSECA, 2003, p.25)

Assim, esse movimento de constituição do sujeito por meio de micro-relações de poder pode ser visto, por exemplo, na progressão das relações entre o protagonista e o conservador ao logo da narrativa, entre o protagonista e o médico, o enfermeiro e, mais ao final, entre ele e o pastor de ovelhas. Cada uma dessas interações reflete uma diferença, para mais, na autoconsciência do protagonista. Os espaços em que se estabelecem tais interações são igualmente carregados desse sentido humanizado e simbólico. Assim, a casa do Sr. José, acoplada à Conservatória, a porta fechada impedindo a passagem de um espaço para outro, tudo isso cede lugar, no final, ao encontro entre o conservador e o Sr. José na casa deste. Nesse episódio a função de vigilante do conservador e a subalternidade do protagonista são substituídas por uma relação de cumplicidade, revelando uma possível transformação de ambos no que se refere às suas respectivas condições de sujeito.

Em síntese, é notória a importância do elemento espacial em Todos os nomes. Observa-se que ele promove, especialmente, uma revisitação de uma das esferas representativas do poder instituído, no caso a Conservatória do Registro Civil. Nos primeiros capítulos, destinados a introduzir o leitor nesse espaço institucional, a descrição detalhada da distribuição dos móveis, da divisão de tarefas, assim como a 
linguagem corporal e o discurso autoritário (mesmo que apresentado com a ajuda da voz narrativa), apresentam, ainda alegoricamente, um microcosmo do poder disciplinar, com os instrumentos que garantem o desenvolvimento das várias atividades que compõem o modo de produção no capitalismo industrial e que foram explorados nas obras de Michel Foucault.

Em relação à arrumação dos móveis e à distribuição dos funcionários, existe, no espaço da Conservatória, uma aparente sobreposição dos primeiros em relação aos funcionários, como se estes fossem apenas figuras acessórias. No entanto, a organização espacial nesse local de trabalho parece corresponder ao modo como, naquilo que Foucault denominou de sociedade disciplinar ${ }^{4}$, se estabelece a economia do poder, com vistas à agilização da produção:

\begin{abstract}
No espaço investido pelos mecanismos disciplinares, cada indivíduo tem o seu lugar e todos os lugares têm a sua destinação. Não há espaços vazios que permitem uma utilização "despersonalizada". Todo lugar deve ser identificado a seu ocupante, que, por sua vez, deve ser identificado ao lugar que ocupa. (FONSECA, 2003, p.63)
\end{abstract}

De fato, entre os instrumentos da disciplina enumerados em Vigiar e Punir, Foucault dá um destaque especial à organização espacial, enfatizando que ela deve ser celular e serial, ou seja, os indivíduos não devem ser isolados, mas sim separados, de modo a que se possam estabelecer relações operatórias entre eles (Ibid.).

Como a disciplina destina-se a controlar não o resultado da ação, mas todos os passos do seu desenvolvimento, a distribuição dos funcionários no espaço é um prérequisito extremamente importante para a eficiência da produção. Talvez a organização espacial seja o instrumento essencial para se alcançarem os resultados almejados. Com base no sistema prisional e na idealização, por Jeremy Bentham, de uma arquitetura que possibilitasse a vigilância absoluta (sem que os presos se soubessem vigiados), Foucault

${ }^{4}$ Entre as características da sociedade disciplinar, para Foucault, estão a descentralização do poder e a transferência do poder de sujeição a determinados mecanismos disciplinares, controlados essencialmente pelo Olhar Vigilante. Conforme Fonseca, "a vigilância como instrumento de disciplina tem como objetivo capacitar o olhar do aparelho disciplinar a uma visão total e permanente". Para o poder que vigia resta o papel de olhar, e não mais coagir pela força física. O indivíduo vigiado é que se transforma no princípio de sua própria sujeição $(2003$, p.57) 
desenvolveu o conceito de "poder panóptico", constituído a partir do princípio da vigilância rigorosa, totalizante e totalitária, porém não identificada pelos que são vigiados. Com a mesma finalidade, trabalha-se com o "encaixamento espacial de vigilâncias hierarquizadas" (Id.)., exatamente como o leitor pode ver pelo sistema de trabalho na Conservatória, em que o conservador fica atrás de todos, mas não é visto por nenhum dos funcionários. O resultado disso é o cumprimento das funções disciplinares do sistema, abrangendo desde a disposição espacial até a composição das forças envolvidas no processo de produção serial, passando ainda pelo controle das atividades e da capitalização do tempo (cf. FONSECA, 2003)

Para compreender melhor o funcionamento desse sistema e acompanhar a evolução das interações pessoais no interior da Conservatória e dos demais espaços (institucionalizados ou não) do romance, convém transcrever aqui a concepção foucaultiana de "disciplina" ou, melhor dizendo, de "disciplinas":

Com efeito, em Todos os Nomes Saramago parece pretender construir um universo socioeconômico em que a disciplina leva sutilmente à submissão dos indivíduos às diversas esferas de poder, promovendo a sua docilização e ductilidade em benefício dos interesses dominantes. Em função da relevância do seu papel nos aparelhos institucionais que compõem a sociedade burocrática e, principalmente, na construção do espaço em Todos os Nomes, convém transcrever o conceito não de disciplina, mas de "disciplinas" em Foucault:

As disciplinas não devem ser identificadas com uma instituição, mas com a conexão de várias técnicas diferentes que seriam aplicadas sobre os lugares institucionais, de tal forma que nunca seriam redutíveis a essas instâncias. São métodos que possibilitam um controle minucioso do corpo e de suas partes, das atividades, do tempo e das forças. (Id., p.70)

Agora já é possível reconhecer melhor a construção desse tipo de sistema relacional no interior deste romance de Saramago. No fragmento a seguir, por exemplo, o relato do narrador, ainda que ressalve a distribuição hierárquica dos lugares e deixe implícita a impessoalidade reinante no ambiente burocrático, destaca (com sutil ironia) a harmonia dessa geometria espacial: 
(...) Logo depois da porta aparece um alto guarda-vento envidraçado de dois batentes por onde se acede à enorme sala rectangular onde os funcionários trabalham, separados do público [...] A disposição dos lugares na sala acata naturalmente as precedências hierárquicas, mas sendo, como se esperaria, harmoniosa deste ponto de vista, também o é do ponto de vista geométrico, o que serve para provar que não existe nenhuma insanável contradição entre estética e autoridade (...). (TN, p. 11-12)

Em seguida, menciona a distribuição dos cargos de acordo com os lugares ocupados, justificando a expressão usada anteriormente a respeito da relação entre "estética e autoridade", confirmando essa utilização do espaço como integrante da metodologia disciplinar:

(...) A primeira linha de mesas, paralela ao balcão, é ocupada pelos oito auxiliares de escrita a quem compete atender o público. Atrás dela igualmente centrada em relação ao eixo mediano que, partindo da porta, se perde lá ao fundo, nos confins escuros do edifício, há uma linha de quatro mesas. Estas pertencem aos oficiais. A seguir a eles vêem-se os subchefes, e estes são dois. Finalmente, isolado, sozinho, como tinha de ser, o conservador, a quem chamam chefe no trato quotidiano (...). (TN, p. 12)

Percebe-se, como já se disse, que as funções hierárquicas assumidas pelas personagens aparecem representadas pela distribuição dos móveis, sendo que as oito mesas dos auxiliares de escrita aparecem próximas ao balcão de atendimento ao público, seguidas, por sua vez, por uma outra fileira composta de quatro mesas que são ocupadas pelos oficiais; após esta fileira aparece a dos dois subchefes e, por último, no ápice desta pirâmide hierárquica aparece o conservador. Por essa distribuição das mesas se vai fazendo contato com o aparato do poder e com seus mecanismos de sustentação. Constata-se ainda, pela descrição da quantidade de trabalho realizada pelos funcionários dependendo do cargo que ocupam na Conservatória, que, quanto menor a posição ocupada dentro da escala hierárquica, maior é o volume de serviços que terá que realizar. Aos auxiliares de escrita, como o Sr. José (que até esse momento não é nomeado), é reservada a maior parte do trabalho da Conservatória. A eles é destinado o peso dos serviços burocráticos, o que leva a crer que os que se situam na base da 
pirâmide, como o Sr. José, é que executam a maior parte das atividades da Conservatória. Este retrato do ambiente burocrático, além de compor um desenho das relações de trabalho na sociedade contemporânea (seguindo as concepções teóricas de Michel Foucault), também revela a intenção de Saramago de colocar a nu os mecanismos do serviço burocrático, retirando-lhe as máscaras e examinando esse sistema a partir de seu interior. Além disso, o modo como o narrador descreve a divisão do trabalho, em que os detentores do poder são os que menos trabalham enquanto os auxiliares, que ocupam a base da pirâmide, são os explorados, deixa entrever a visão marxista do escritor em relação à realidade capitalista.

Também são visíveis, entre os que integram o corpo de funcionários da Conservatória, as demonstrações de poder expressas através da expressão corporal, seja pela expressão facial, seja pelo sentido da visão. Como já foi visto na teoria e pode ser aplicado no interior desta obra de Saramago, o poder não é centralizado, mas expandese por todos os integrantes daquela "microesfera de poder". Além disso, trata-se de um poder que não existe em substância, mas em exercício, ou seja, na prática.

Foucault, em sua Microfisica do poder, afirma que o poder, a partir do século XVIII, com a reforma do direito criminal, e mais especificamente a partir do século XIX, quando se inicia o desenvolvimento do capitalismo industrial, não está mais centralizado na mão de um só indivíduo (o monarca, no caso do século XVIII), a quem poderíamos imaginar como um ditador, mas existe de forma distribuída entre todos que a ele se submetem.

Em Todos os Nomes fica compreensível que o poder emane dos próprios funcionários, cujos gestos demonstram a sua reprovação no que diz respeito a certas atitudes consideradas inadmissíveis por parte do Sr. José. Por exemplo, observam-se certas atitudes de censura, certos gestos dos colegas quando o Sr. José começa a chegar 
atrasado ao trabalho, a descuidar-se da aparência, a ponto de vir a ser chamado para uma conversa particular com o conservador. Neste momento como se estivessem adotando uma postura de reprovação e censura pelos atos do "infrator", eles começam a encher a sua mesa de papéis e deixar o balcão de atendimento ao público ao encargo dele.

Já o conservador, como representante máximo do poder vigilante, em sua conversa, exigirá do Sr. José que, dirija o seu olhar só para ele: (...) Distraí-me, senhor, Mau sinal, sabe que tem de olhar sempre para mim quando lhe falo, é do regulamento disciplinar, eu sou o único que tem o direito a desviar os olhos (...)”.(TN, p. 11)

Logo após a conversa com o conservador, o Sr. José retorna a sua mesa e depara-se com uma quantidade estúpida de papéis sobre ela, ao mesmo tempo que o balcão de atendimento parece solicitar somente a sua pessoa. Neste episódio, o narrador intervém ao comparar os gestos dos colegas do Sr. José com um castigo:

(...) Durante os poucos minutos que havia durado a difícil conversação com o chefe, o trabalho acumulara-se na sua mesa, como se os outros auxiliares de escrita, seus colegas, aproveitando-se da periclitante situação disciplinar em que o viam, tivessem também querido, por sua própria conta, castigá-lo. Além disso, umas quantas pessoas esperavam a sua vez de serem atendidas (...) $(T N$, p. 79).

Observa-se, neste fragmento, a que ponto o poder instituído encontra-se impregnado nos funcionários: não somente do conservador emanam as sanções, mas estas advêm também dos próprios colegas do Sr. José.

Um outro elemento coercitivo em Todos os nomes é o discurso autoritário. Ele é usado pelo conservador, predominantemente como forma de legitimar o seu poder como representante máximo da burocracia. O trecho a seguir, no entanto, é extraído de um momento de transformação na constituição do conservador enquanto sujeito. Trata-se do episódio em que ele deixa manifesta uma atitude de revisão da ordem vigente na 
Conservatória e expressa sua decisão de modificar a disposição dos Arquivos dos Vivos

e dos Mortos, promovendo uma aproximação espacial entre eles:

(...) Meus senhores, na qualidade de chefe desta Conservatória Geral do Registo Civil [...] tenho cumprido e feito cumprir com o maior escrúpulo as leis escritas que regulam o funcionamento dos serviços, sem ignorar, e pelo contrário tendo-a bem presente em cada momento, a tradição [...]. Farei baixar portanto uma ordem de serviço em que se especificará, primeiro, que a partir desta data os mortos permanecerão no mesmo lugar do arquivo que tinham ocupado em vida, segundo que progressivamente, processo a processo, documento a documento, dos mais recentes aos mais antigos, se procederá à reintegração dos mortos do passado no arquivo que passará a ser o presente de todos [e] a disciplina nesta Conservatória Geral continuará a ser a que sempre foi [...] nenhuma palavra que não esteja directamente relacionada com o serviço (...) $(T N$, p. 206-210).

Mas, num episódio anterior, esse discurso é "usurpado" pelo protagonista, que

falsifica uma credencial para conseguir obter as informações sobre a mulher

desconhecida. Na verdade, o Sr. José, pelo discurso, sente que se apropria também do

poder que tal discurso incorpora:

(...) Em nome dos poderes que me foram conferidos e que debaixo de juramento mantenho, aplico e defendo, faço saber, como Conservador desta Conservatória Geral do Registo Civil, a todos quantos, civis ou militares, particulares ou públicos, vejam, leiam e compulsem esta credencial escrita e firmada de meu punho e letra, que Fulano de tal, auxiliar de escrita a meu serviço e da Conservatória Geral que dirijo, governo e administro, recebeu directamente de mim a ordem e o encargo de averiguar e apurar tudo quanto diga respeito à vida passada, presente e futura de Fulana de Tal (..) devendo, portanto, sem mais comprovações, serem nele reconhecidos, como seus próprios, e por todo tempo que a investigação durar, os poderes absolutos que, por esta via e para este caso, delego na sua pessoa. Assim o têm exigido as conveniências do serviço conservatorial e o decidiu a minha vontade. Cumpra-se (...) (TN, p. 57).

No trecho a seguir, está indiretamente registrada a surpresa do próprio Sr. José

diante da mudança de comportamento que lhe ocorre após se apropriar da palavra do

poder:

(...) Trémula de susto, tendo a duras penas acabado de ler o impressionante papel, a tal criança correu a proteger-se no regaço da mãe, perguntando-lhe como foi possível que um auxiliar de escrita como este Sr. José, tão pacífico de seu natural, tão cordato de costumes, tenha sido capaz de conceber, de inventar na sua cabeça, sem dispor de um modelo anterior por onde guiar-se 
[...], a expressão de um poder a tal ponto despótico, que é o mínimo que deste se pode dizer (...) (TN, p. 57)

Os discursos proferidos pelo conservador e incorporados pelo Sr. José podem ser compreendidos como a "palavra autoritária", de que nos fala Bakhtin, em Questões de literatura e de estética - A teoria do romance:

\begin{abstract}
A palavra autoritária exige de nós o reconhecimento e a assimilação, ela se impõe a nós independentemente do grau de sua persuasão interior no que nos diz respeito; nós já a encontramos unida à autoridade. A palavra autoritária, numa zona mais remota, é organicamente ligada ao passado hierárquico. É, por assim dizer, a palavra dos pais. Ela já foi reconhecida no passado. É uma palavra encontrada de antemão. Não é preciso selecioná-la entre outras equivalentes. Ela ressoa numa alta esfera, e não na esfera do contato familiar (BAKHTIN, 2002, p. 143).
\end{abstract}

Ao proferir o discurso da autoridade, o conservador nada mais faz que apropriarse e, ao mesmo tempo, legitimar-se através do poder da palavra. Quanto ao Sr. José, a apropriação discurso do poder pode ser vista, no contexto da obra, como uma grave infração, como um crime, mas ocorre que os caminhos que o poder lhe abre para conquistar uma ampliação de saberes oblitera suas culpas e, de certa forma, a seus olhos legitima o gesto transgressor.

No diálogo que se estabelece entre o Sr. José e a senhora do rés-do-chão direito, diálogo que lembra os inquéritos referidos por Foucault, a mulher valoriza o protagonista pelo seu poder de acesso ao conhecimento, em função do "cargo" que ele exerce:

(...) O senhor sabe mais do que o seu chefe, Nem pensar, comparado com ele não valho nada, por isso ele é o conservador e eu não passo de um auxiliar de escrita. Ambos sabem o meu nome, É certo, Mas ele não sabe de mim mais do que o meu nome, Nisso tem razão, a diferença é que ele já o conhecia antes, ao passo que eu só fiquei a conhecê-lo depois de receber esta missão, E de um salto passou-lhe à frente, está aqui na minha casa, pode ver-me a cara, ouviu-me dizer que enganei o meu marido, e é, em todos estes anos, a única pessoa a quem o disse, que mais é preciso para convencer você de que, ao pé de si, o seu chefe não passa de um ignorante (...) (TN, p. 62) 
Agora que já foram mostrados os mecanismos que sustentam as relações de poder na esfera da Conservatória (entendida, neste contexto, como um microcosmo da sociedade ocidental na época do capitalismo industrial), convém deixar evidente o já referido processo de passagem dos integrantes do sistema, da condição de "assujeitamento" para a condição de sujeitos portadores de uma consciência da própria identidade.

Tal movimento, que constitui, de fato, o eixo ao redor do qual tudo constela na narrativa de Todos os Nomes, envolve, fundamentalmente, o Sr. José e o conservador, compondo cada um deles uma faceta do mesmo todo, na medida em que, na perspectiva aqui adotada (que abrange as teorias tanto de Bakhtin quanto de Foucault), o sujeito se constitui sempre mediante situações de relação com os outros. Tendo isso em mente, é possível compreender as figuras do Sr. José e do conservador como os principais integrantes desse processo - como o "eu" e o "tu", um ajudando o outro no reconhecimento da sua condição de sujeito.

Já foi esclarecido o processo como o ser humano se constitui em sujeito ou, mais especificamente, no indivíduo moderno da concepção foucaultiana (aquele que é objeto dócil e útil e, ao mesmo tempo, sujeito portador de uma consciência de si mesmo). Agora, resta ver como, para Bakhtin, a prática das relações sociais atua na constituição do sujeito.

É importante repetir que, na concepção de Foucault, os mecanismos de poder que promovem o assujeitamento contêm em seu bojo o elemento da resistência e, nesta medida, ao mesmo tempo que reprimem, são produtivos, pois induzem o indivíduo ao movimento de tomada de consciência de si mesmo. Para Bakhtin, o processo de constituição do sujeito também ocorre no seio da interação social, demandando, como para Foucault, o encontro entre o "eu" e o "outro" e implicando também a idéia de 
resistência. No conceito bakhtiniano de diálogo (no sentido amplo de "simpósio universal") está contida a idéia de resistência, pois ele se dá no ponto de tensão entre vozes sociais e envolve o choque entre forças centrípetas e centrífugas. Como explica Faraco:

O diálogo (no sentido amplo de "simpósio universal") pode ser entendido como um vasto espaço de luta entre vozes sociais (uma espécie de guerra dos discursos), no qual atuam forças centrípetas (aquelas que buscam impor uma certa centralização verboaxiológica por sobre o plurilingüismo real) e aquelas centrífugas (aquelas que corroem continuamente as tendências centralizadoras (FARACO, 2003, p.60)).

O dialogismo é um conceito central na teoria de Bakhtin sobre a linguagem, pois explicita a existência da heterogeneidade social e a idéia do embate entre diferentes verdades sociais, sem que, no entanto, exista, ao final, a vitória de uma dessas verdades. Fica evidente, então, que, para Bakhtin (assim como para Foucault) não há condição de superação das contradições sociais. Portanto, a comunicação social, base da tomada de consciência de si mesmo pelo indivíduo, implica a presença do choque com os enunciados alheios (com outras vozes sociais, portanto) e um choque que não envolve a anulação de nenhuma das vozes nem a sobreposição de uma voz pela do outro. Em Para uma refeitura da obra de Dostoiévski, de 1961, diz Bakhtin acerca desse processo:

VIVER significa tomar parte no diálogo: fazer perguntas, dar respostas, dar atenção, responder, estar de acordo e assim por diante. Desse diálogo, uma pessoa participa integralmente e no correr de toda sua vida: com seus olhos, lábios, mãos, alma, espírito, com seu corpo todo e com todos os seus feitos. Ela investe seu ser inteiro no discurso e esse discurso penetra no tecido dialógico da vida humana, o simpósio universal. (in FARACO, p. 73)

Em "Dialogismo, Polifonia e Enunciação", Diana Barros afirma que só se pode compreender a concepção bakhtiniana de dialogismo relacionada ao "deslocamento do conceito de sujeito". Este, ao perder o seu "papel de centro, é substituído por diferentes 
vozes sociais, que fazem dele um sujeito histórico e ideológico" (BARROS, 1994, p. 2$3)$.

De fato, são essas muitas vozes sociais que começam a emergir no tecido da narrativa desde que o Sr. José inicia suas investigações sobre a mulher desconhecida. Trata-se de um movimento de saída do espaço fechado e funesto da Conservatória para um mundo aberto a novas possibilidades, um movimento de abandono da função de simples copista em direção ao exercício de outras funções, a começar pela de intérprete dos signos do mundo por meio da interação (que jamais ocorreu enquanto foi apenas o obediente e submisso funcionário da Conservatória).

$\mathrm{Na}$ verdade, o período de "assujeitamento", em que esteve submisso passivamente ao poder disciplinar da Conservatória, corresponde, na concepção bakhtiniana, ao período em que o Sr. José viveu na condição de "Não Ser", de "morte absoluta", não sendo lembrado, não sendo ouvido, não participando, enfim, do processo de interação social. A narrativa de Todos os Nomes desenha a trajetória labiríntica, ininterrupta e infindável, desde o estado de Não Ser até a condição (não definitiva) de Ser. Tal trajetória se dá por entre as malhas do tecido social, envolvendo figuras que não têm nome, mas são reconhecidas por seus papéis sociais (o enfermeiro, o pastor etc.), mas envolvendo principalmente a personagem Sr. José e seu duplo, o conservador (personificação do poder instituído), além da mulher desconhecida, que, por sua vez, parece simbolizar o objeto de desejo que motivará todo o processo de crescimento do protagonista (crescimento que terá, como mostra o desenrolar da trama, ressonâncias em todo o sistema social).

Portanto, é possível observar, a esse respeito, que existe uma mudança gradativa no ritmo da narrativa a partir da primeira transgressão do protagonista, uma atenuação do "peso" e da fria austeridade do discurso burocrático dos capítulos iniciais. 
Retomando as palavras de Bakhtin transcritas acima, é como se a própria vida estivesse penetrando no cotidiano aborrecido do Sr. José, por meio dos desafios que a investigação demandava e graças à mola propulsora do desejo e das interações pessoais que passam a acontecer desde então.

São múltiplas vozes, muitos diálogos, o narrador tornando-se apenas mais uma voz (e não a voz hegemônica e controladora do romance monológico), o que conduz ao enquadramento de Todos os Nomes entre os romances polifônicos e do reconhecimento do Sr. José como um herói afinado com o herói ideólogo de Dostoiévski.

Para compreender melhor o que se acaba de afirmar, convém retomar as palavras de Bakhtin sobre os conceitos de polifonia e de herói ideólogo, ambos extraídos de Problemas da poética de Dostoievski.

Acerca da polifonia, depois de advertir que não se deve confundir polifonia com dialogismo, Bakhtin explica que ela constitui um novo modo de narrar, um modo de narrar que é específico de Dostoiévski:

\footnotetext{
A multiplicidade de vozes e consciências independentes e imiscíveis e a autêntica polifonia de vozes plenivalentes constituem a peculiaridade fundamental dos romances de Dostoiévski. Não é a multiplicidade de caracteres e destinos que, à luz da consciência una de um autor, se desenvolve nos seus romances; é precisamente a multiplicidade de consciências eqüipolentes e seus mundos que aqui se combinam numa unidade de acontecimento, mantendo a sua imiscibilidade. Dentro do plano artístico de Dostoiévski, suas personagens principais são, em realidade, não apenas objetos do discurso do autor, mas os próprios sujeitos desse discurso diretamente significante (BAKHTIN, 2005, p. 4)
}

Tomando como base as explicações dadas por Bakhtin acerca das personagens, que, nas obras de Dostoiévski, desvinculam-se da dependência do autor e ganham sua própria autonomia como sujeitos, já fica mais fácil de compreender como o pensador concebe o herói ideólogo típico das obras de Dostoiévski.

É ainda na sua obra sobre Dostoiévski que Bakhtin vai desenvolver suas análises sobre as personagens do romancista russo. A base para se compreender a concepção 
bakhtiniana de herói ideólogo está, primeiro, na sua constatação da independência do pensamento desse herói em relação ao autor (entendido aqui como autor criador, categoria ficcional do romance). Num segundo momento, é preciso ter em mente que o herói "não é apenas um discurso sobre si mesmo e sobre seu ambiente imediato, mas também um discurso sobre o mundo". (Bakhtin, 2005, p. 77) Ou seja, ele é portador de uma ideologia própria (possui, portanto, competência ideológica) e está aberto a reformulações na sua autoconsciência a partir das relações dialógicas.

Sobre o mesmo assunto diz ainda Bakhtin:

O pensamento humano só se torna pensamento autêntico, isto é, idéia, sob as condições de um contato vivo com o pensamento dos outros, materializado na voz dos outros, ou seja, na consciência dos outros expressa na palavra. É no ponto desse contato entre vozes - consciências, que nasce e vive a idéia (BAKHTIN, 2005, p. 86).

A dinâmica expressa por Bakhtin no excerto acima é a que se vê em Todos os Nomes. De fato, o romance apresenta o confronto de muitas vozes, incluindo-se entre elas a voz do autor. Além disso, a personagem Sr. José também passa por crescentes transformações no desenrolar da narrativa. No início, por exemplo, percebe-se que o protagonista ainda se encontra num estágio de cegueira, semelhante à dos seus colegas. Apenas se nutre de sua rotina de funcionário, cumpridor de seus deveres, sem ter ninguém no mundo para compartilhar das suas insatisfações ou mesmo da sua coleção de famosos. Somente o teto do seu quarto faz as vezes de confidente virtual. Porém, quando resolve dar o seu primeiro passo rumo à transgressão das normas disciplinares, no momento em que entra na Conservatória pela porta de acesso proibido, o Sr. José vai descobrindo o sabor do acesso ao conhecimento e começa a achar emocionante e até mesmo natural a sua atitude.

Mas o seu objeto mágico, nome tomado de empréstimo de Beatriz Berrini em sua obra Ler Saramago - o romance, será o verbete da desconhecida. Este se 
transformará na causa do seu desejo de livrar-se das amarras que o mantinham preso à Conservatória.

A tese defendida nesta análise parte do princípio de que a busca empreendida pelo Sr. José é de cunho existencial e essencial, na medida em que ela constitui uma busca pela essência, isto é, a conquista da sua autoconsciência. Mesmo depois de tomar ciência do suicídio da mulher desconhecida, o protagonista irá continuar a sua procura, para saber detalhes sobre o motivo da morte desta mulher. E, no momento em que se depara com a realidade de que os números contidos nas placas dos túmulos dos suicidas eram todos trocados para que as suas identidades não fossem reveladas; ele termina imbuindo-se de um novo sentido para sua procura. Quer dizer, mesmo sabendo da morte da desconhecida, ele continuará a investigar os possíveis motivos que a teriam levado a tirar sua própria vida. No entanto, o máximo que conseguirá é ter contato com os seus objetos pessoais, móveis, roupas, através da sua visita a casa desta mulher. Somente por meio de uma secretária eletrônica, o protagonista conseguirá ouvir a voz da mulher por quem se sentiu identificado, porém não chegou a tempo de encontrá-la.

Ao reagir, o protagonista demonstra que, mesmo diante dos limites, não é possível ficar imune aos acontecimentos. A reação, portanto, constitui o primeiro passo rumo ao inconformismo. No momento em que resolve reagir ao sistema desumanizado em vigor no seu local de trabalho, Sr. José está tentando dar algum sentido à sua vida e vai construindo uma outra história nos bastidores da vida, tornando-se o senhor dos arquivos. Porém o próprio final da narrativa elucida a falta de acabamento da história, pois enquanto houver vida, a busca continua.

Numa das passagens do seu livro Ler Saramago: O romance, Beatriz Berrini fala da atuação do protagonista em Todos os nomes em sentir-se impelido a uma busca 
incansável que parece ir além do simples achamento de uma desconhecida. Assim ela argumenta:

\begin{abstract}
O romance valoriza a busca, não a posse dos objectos desejados e procurados, ou o encontro de soluções para os problemas com que cada um se defronta. Se ao fim da vida tivermos as mãos vazias, outros continuarão a procura, tornarão seus os estímulos que nos impeliram a procurar incansavelmente e, assim irá viver. A vida de cada um tem em si mesma a sua justificação pelo simples facto de ter procurado, pela sua não conformação com a realidade do mundo. Nessa continuidade reside a razão de viver (BERRINI, 1998, p. 137).
\end{abstract}

Portanto, por obra do protagonista o poder burocrático existente na Conservatória será, aos poucos, desconstruído. O Sr. José terá um grande aprendizado assim como o seu chefe, ambos empreendendo mudanças em suas práticas. O Sr. José enquanto empreendedor de uma procura, que parece não ter um desfecho, e o conservador ao adotar uma atitude de cumplicidade com o auxiliar de escrita e promover alterações na organização dos arquivos da Conservatória. Tudo isso metaforizando as mudanças que ocorrem diuturnamente nas práticas sociais e nas diversas esferas do poder e nas diversas visões ideológicas. Como uma alegorização da utopia bakhtiniana do diálogo sem fim, explicada por Faraco da seguinte forma:

O diálogo sem fim é a única forma de sobrepujar o monologismo, a única forma de preservar a liberdade do ser humano e de seu inacabamento; o diálogo sem fim, portanto, é uma relação em que o outro nunca é reificado; em que os sujeitos não se fundem, mas cada um preserva sua própria posição de extra-espacialidade e excesso de visão e a compreensão daí advinda (FARACO, 2003, p. 74) 


\title{
2. A figura do Sr. José entre o não ser e o ser
}

\begin{abstract}
"A verdade é sempre inverossímil; para lhe dar verossimilhança é preciso misturar-lhe um pouco de mentira." 5
\end{abstract}

Dostoiévski

Num dos ensaios de Sociologia da burocracia, Max Weber, esclarecendo acerca da estrutura burocrática, acentua que, nessa forma de relacionamento, a direção das atividades coletivas fica a critério de uma "ordem impessoal para a qual se orientam suas ações (...) e que a organização dos cargos obedece ao princípio da hierarquia, em que cada cargo inferior está sob o controle e supervisão do superior [e] cada cargo é considerado como a principal ocupação do funcionário e este, por sua vez, está sujeito a uma rigorosa e sistemática disciplina e controle no desempenho do cargo (...)" (WEBER, 1966, p. 18-21).

Além disso, o autor também explica que é inerente ao modelo burocrático o rigor disciplinar, assim como a obediência. Esta pode ser vista como um meio ou um fim em si mesmo. No primeiro caso, ela é encarada como a forma mais eficiente para se alcançar um determinado fim e, no segundo caso ela é concebida como um fim em si mesmo, não admitindo nenhum questionamento (Id., p. 56-57).

Como foi visto no capítulo anterior, a impessoalidade e a disciplina são elementos dominantes nos ambientes institucionalizados de Todos os nomes, tais como a Conservatória, a escola, o cemitério. De fato, o romance é a alegoria do sistema burocrático e, nele, constata-se o quanto falta, nesse sistema, de espaço para qualquer manifestação espontânea ou de cunho pessoal. $\mathrm{Na}$ verdade, interessa apenas que as

\footnotetext{
${ }^{5}$ AMALFI, Francis. A oficina dos escritores. Inspirações sobre a arte de escrever, a literatura e a vida. Lisboa: Editorial Estampa, 2007. p.75
} 
ações coletivas sejam suficientemente eficientes para gerar os resultados esperados. Diz Max Weber:

\begin{abstract}
A burocracia proporciona o máximo de segurança profissional, [seu] principal mérito está na sua eficiência técnica devido à ênfase que dá a precisão, rapidez, controle técnico, continuidade, discrição e por suas ótimas quotas de produção. A estrutura está concebida para eliminar por completo as relações do tipo pessoal e as considerações emocionais (hostilidade, ansiedade, vínculos afetivos etc.). (Ibid, p. 99)
\end{abstract}

Tal é o ambiente em que vive o Sr. José, personagem também alegórica, cujo nome já traz, a um primeiro olhar, os traços típicos do indivíduo moderno que integra o sistema burocrático de trabalho. Não é demais relembrar aqui que se trata, neste caso, do "sujeito dócil e útil" (dúctil também) a que se refere Foucault nos seus trabalhos sobre as relações entre os micropoderes e a construção do sujeito por meio de práticas discursivas de poder. Mas o nome do protagonista, Sr. José, traz reverberações bíblicas e, subliminarmente, pode evocar a simplicidade (e a sacralidade) do pai de Jesus e a modalidade de trabalho artesanal que ele executava - como se, no desenvolvimento da trama, o Sr. José, oficiosamente, pudesse estar fazendo um trabalho de "carpintaria", construindo artesanalmente a si mesmo (e construindo, por extensão, o seu meio ambiente).

Assim, "oficialmente" o Sr. José é um simples escrevente da Conservatória Geral do Registro Civil, cumpridor de seus deveres, que mora numa habitação colada ao prédio da Conservatória (sua habitação reflete as condições precárias em que vive; pela descrição, trata-se de um cubículo com alguns poucos objetos para o seu uso diário). Vive em meio a um vazio existencial e não consegue reconhecer-se em nenhuma atividade. O seu trabalho consiste em cumprir todas as determinações burocráticas, seja no que diz respeito ao horário de chegada e de saída, seja quanto à forma de se vestir e de se comportar. Não interage com nenhum outro funcionário e as suas ações 
restringem-se a atender de forma respeitosa às solicitações do conservador. Sua rotina é, enfim, calcada na impessoalidade: tanto ele quanto os demais funcionários apenas cumprem as normas disciplinares de forma mecânica e estão completamente impregnados por elas.

Nos finais de semana, o Sr. José ocupa o seu tempo de indivíduo solitário a colecionar curiosidades sobre a vida de pessoas famosas. $\mathrm{Na}$ verdade, nem essa atividade parece ter muito sentido para ele, pois aquelas pessoas não possuem nenhuma relação com a sua vida. O leitor tem a impressão de que, se lhe perguntasse o porquê da sua coleção, ele apenas responderia que não havia um motivo maior para ela; apenas o fazia como uma forma de matar o tempo:

(...) Pessoas assim, como este Sr. José, em toda a parte as encontramos, ocupam o seu tempo ou o tempo que crêem sobejar-lhes da vida a juntar selos, moedas, medalhas, jarrões, bilhetes-postais, caixas de fósforos, livros, relógios, camisolas desportivas (...), provavelmente fazem-no por algo a que poderíamos chamar angústia metafísica, talvez por não conseguirem suportar a idéia do caos como regedor único do universo (...) (TN, p. 23)

No entanto, a ação deste romance de Saramago não gira em torno do vazio existencial do protagonista, mas, muito ao contrário, da busca de um sentido para sua vida, busca que se dá "oficiosamente".

Sob essa perspectiva, este trabalho parte do pressuposto de que o herói em Todos os nomes possui um caráter inacabado. Portanto, ele deve ser visto entre a obediência ao poder instituído - representado pela Conservatória Geral e a sua rebeldia a este poder. Percebe-se que, no início da narrativa, ele se apresenta como um funcionário exemplar, cumpridor dos regulamentos burocráticos próprios da instituição. Porém, como já se viu, ele vai começando a descumprir algumas normas da instituição, tais como usar a chave que possuía ao seu alcance para entrar na Conservatória fora do horário de 
expediente, em busca de informações adicionais para a sua coleção de recortes de pessoas famosas, até tomar contato com o verbete da desconhecida, que constituirá o motivo da sua crescente procura pela reconstituição de vida da anônima, assim como assumir o papel de "verdadeiro senhor dos arquivos."

Em síntese, ao longo da narrativa haverá uma progressão no sentido da submissão para a transgressão ou, em outras palavras, da subalternidade alienante para a conquista da autoconsciência. Assim, a busca pelos dados da mulher desconhecida transcende, na verdade, os limites da mera informação sobre uma pessoa qualquer, adquirindo uma amplitude de teor ontológico, na medida em que a busca converge para o encontro do próprio ser consigo mesmo, porém por meio das relações dialógicas.

Foi dito acima (e também anteriormente) que, em Todos os Nomes, se faz uma alegoria do sistema burocrático típico dos nossos tempos. Mas também se pode ver na obra a alegoria da sua contrapartida, isto é, a alegoria da dinâmica da Vida (em oposição à carga semântica de imobilidade e de morte visível no espaço da Conservatória, referida também como "caverna" e como "túmulo").

Dentro do pensamento de Bakhtin a idéia da busca ocupa um papel central: “O modo como eu crio a mim mesmo é por meio de uma busca: eu saio ao encontro de um outro e volto com um self" (CLARK e HOLQUIST, 1998, p. 102) Trata-se de uma busca que ocorre no mundo, durante o percurso da existência humana e pressupõe o diálogo com o outro, considerado, tal como "eu", um "autor" da sua "atividade ética".

De acordo com a concepção de Bakhtin, autorar, nesta perspectiva, é orientar-se na atmosfera heteroglótica; é assumir um posição estratégica no contexto de circulação e da guerra as vozes sociais; é explorar potencial de tensão criativa da heteroglossia dialógica; é trabalhar nas fronteiras (FARACO, 2003, p. 83). 
Em Todos os Nomes o leitor acompanha a trajetória "labiríntica", sinuosa, da busca do Sr. José pela construção do seu self, busca que se processa no contato com outros entes, que também irão se beneficiar dessas trocas e também irão participar da mesma "arquitetônica", comportando-se de forma igualmente responsável e ética durante sua atividade existencial.

Pode-se conceber a busca do Sr. José como um "tratado ético" tal como o existente na Arquitetônica da Respondibilidade; a sua trajetória alegoriza o que Katerina Clark e Michael Holquist expõem muito apropriadamente acerca desse tema basilar do pensamento bakhtiniano:

\begin{abstract}
nós próprios precisamos ser responsáveis ou respondíveis por nós mesmos. Cada um de nós ocupa um lugar e um tempo únicos na vida, uma existência que é concebida não como um estado passivo, mas ativamente, como um acontecimento. Eu calibro o tempo e o lugar da minha própria posição, que está sempre mudando, pela existência de outros seres humanos e do mundo natural por meio dos valores que articulo em atos. (Id., 1998, p.90)
\end{abstract}

Pode-se, inclusive, pensar que, nesta obra de Saramago, o trabalho arquitetônico se dá em dois sentidos que se opõem, se conflitam permanentemente, porém de forma paradoxalmente produtiva. Se, de um lado, tem-se o poder instituído preocupando-se com a edificação de uma arquitetura física a serviço da organização político-econômica, de outro, tem-se o sujeito agindo no sentido da construção e sedimentação da sua arquitetônica da respondibilidade. Bakhtin reconhece como elementos integrantes dessas relações dialógicas, as forças centrípetas, monológicas e autoritárias, e as forças centrífugas, bivocais ou híbridas, constantemente abertas a mudanças. Cada um destes dois pólos está atuando em prol de uma das duas arquitetônicas mencionadas: o pólo centrípeto está voltado para o favorecimento do poder instituído, o centrífugo atua no sentido das relações dialógicas saudáveis. 
Este capítulo procura analisar a trajetória do protagonista, com o objetivo de examinar o peso axiológico de seus atos, com vistas a refletir sobre a construção da sua autoconsciência. Como a consciência individual se constrói sempre no interior das relações dialógicas, não será possível levar em consideração as atitudes do Sr. José, desconsiderando as daqueles com quem ele se interrelaciona, principalmente o conservador, que pode, neste contexto, ser inclusive, visto como seu duplo.

Ironicamente (mas típico da narrativa saramaguiana), o movimento de busca efetuado pelo Sr. José se dá a par de um movimento de rejeição do status quo e de si mesmo, de "afastamento", pois a conquista da autoconsciência caminha em paralelo com a "rejeição do que se é", de acordo com o pensamento de Foucault. Também Bakhtin trabalha na mesma linha, integrando no processo de autoconsciência as quatro categorias de aceitação e rejeição, revolta ou resignação (BAKHTIN, 2005, p.77)

As contradições e paradoxos inerentes ao percurso do protagonista, ao mesmo tempo que impedem que a linha percorrida seja compreendida pela lógica do pensamento convencional, permitem que o leitor assimile as numerosas alusões à idéia de labirinto e à necessidade do "fio de Ariadne/rolo de cordel" como recurso auxiliar para o "encontro" do objeto desejado. O termo "encontro" foi colocado entre aspas porque, neste contexto, tem certa conotação irônica, no sentido de que o que o protagonista buscava (a mulher desconhecida) não foi o que encontrou, porém o que encontrou teve com o objeto desejado (mulher/Graal) uma relação metonímica e um resultado muito mais substancial do que o desejado.

De fato, é possível verificar que vai sendo, pouco a pouco, tecida uma rede de significados indicativos da impossibilidade de uma interpretação unívoca de certos elementos da narrativa. Por exemplo, as referências a mitos (como o "labirinto", o "Ciclope" (encontrado como "ciclópico", forma com que a Conservatória é adjetivada, 
numa alusão à sua monumentalidade), ou a "Caverna", outro atributo da mesma

Conservatória) irônica e sutilmente desconstroem o conceito de mito como "verdade

revelada", ou seja, verdade não explicada por meios racionais.

Neste procedimento usado por Saramago reconhece-se a ironia socrática, por

meio da qual Sócrates colocava em xeque o monologismo da verdade contida nos mitos.

Procedendo a uma leitura "arqueológica" das relações intertextuais contidas neste jogo

criado pela ironia, tem-se aqui um caso semelhante ao da "boneca russa" com que se

costumou explicitar o Barroco; na raiz, na origem, a verdade mítica, absoluta,

inquestionável, apreendida pela intuição; depois, a cosmovisão racionalista de Sócrates ${ }^{6}$, interagindo dialogicamente com o pensamento mítico e postulando a relativização dessa

verdade, tal como explicou Bakhtin acerca do conceito socrático de verdade:

O método dialógico de busca da verdade se opõe ao monologismo oficial que se pretende dono de um a verdade acabada, opondo-se igualmente à ingênua pretensão daqueles que pensam saber alguma coisa. A verdade não nasce nem se encontra na cabeça de um único homem; ela nasce entre os homens, que juntos a procuram no processo de sua comunicação dialógica. (BAKHTIN, 2005, p.109-110)

Numa camada superior, uma outra concepção de Verdade, a de Foucault:

O importante, creio, é que a verdade não existe fora do poder ou sem poder (...) A verdade é deste mundo; ela é produzida nele graças a múltiplas coerções e nele produz efeitos regulamentados de poder. Cada sociedade tem seu regime de verdade, sua "política geral" de verdade: isto é, os tipos de discurso que ela acolhe e faz funcionar como verdadeiros; os mecanismos e as instâncias que permitem distinguir os enunciados verdadeiros dos falsos, a

\footnotetext{
${ }^{6}$ A recepção da figura de Sócrates ao longo da evolução da história da Filosofia tem oscilado conforme as épocas. A partir de Nietzsche, particularmente, surgem restrições à figura e ao pensamento de Sócrates. Mas essas restrições e o próprio conceito que Nietzsche faz de Sócrates têm sido repensados. Segue-se a transcrição de um fragmento do estudo sobre Sócrates, extraído de Paidéia: a formação do homem grego: "A sua estrela começa agora [na Reforma] a se elevar, enquanto a de Aristóteles, o príncipe da Escolástica, entra em declínio. Sócrates torna-se o guia de todo o Iluminismo e de toda a filosofia moderna; o apóstolo da liberdade moral, separado de todo dogma e de toda tradição, sem outro governo além daquele da sua própria pessoa e obediente apenas aos ditames da voz interior da sua consciência; o evangelista da nova religião terrena e de um conceito de bem-aventurança atingível nesta vida mercê da força interior do homem e baseada, não a graça, mas na incessante tendência ao aperfeiçoamento do nosso próprio ser." Na continuidade desse texto, Jaeger explica a boa recepção de Sócrates pelo fato de ele ter, aos olhos dos filósofos modernos, contribuído para criar "uma religião moderna, em que o conteúdo da religião de Jesus se fundisse com certos traços essenciais do ideal helênico do homem". (JAEGER, 1995, p. 493-494)
} 
maneira de sancionar uns e outros; as técnicas e os procedimentos que são valorizados para a obtenção da verdade; o estatuto daqueles que têm o encargo de dizer o que funciona como verdadeiro. (FOUCAULT, 1979, p.175)

E a de Bakhtin, que, de verdade, transforma-se em "verdades sociais", segundo explica Faraco:

Ao estudar o plurilingüismo verbal, Bakhtin menciona que existe uma luta entre verdades sociais, mas não entre classes sociais. Não há também, nenhuma possibilidade de superação das contradições. (FARACO, 2003, p. 68)

E, finalmente, a verdade de Saramago em Todos os Nomes, que não é uma, nem é a soma de, mas está sempre em processo, em construção, por meio das relações dialógicas que se estabelecem entre as personagens e que, mudando-se a si mesmas, mudam também as práticas de poder.

Assim, a constatação de que a multiplicidade de vozes traduz a relatividade do conceito de verdade e de que é impossível a superação das contradições sociais, torna compreensível e justificável a presença da ironia socrática como um recurso indicativo do movimento contínuo de "produção" de novas verdades. Conclui-se, portanto, que a Verdade não existe em si mesma, mas é relativa, grupal e passível de ser fabricada, controlada ou manipulada por mecanismos de poder. Em Todos os Nomes, tal manipulação pode ser vista quando o conservador sugere ao Sr. José que sejam destruídos os dados que comprovariam o óbito da mulher desconhecida. Em momentos anteriores, pode ser constatada a relação entre o "nascimento" da verdade e a prática da vigilância por meio do olhar.

A este respeito, chama a atenção, em Todos os Nomes, a mudança na caracterização do olhar ao longo da narrativa. Por exemplo, inicialmente, quando está sendo feita a descrição do ambiente de trabalho na Conservatória, a disposição das mesas pelo espaço, com a mesa do conservador situada sozinha no fundo da sala, atrás 
das outras duas fileiras, remete ao pré-requisito fundamental para o rendimento do trabalho, que é a vigilância, denominada por Foucault de "olhar panóptico". A título de rememoração, convém repetir o trecho, já mencionado à p. 25:

(...) A disposição dos lugares na sala acata naturalmente as precedências hierárquicas (...). A primeira linha de mesas, paralela ao balcão, é ocupada pelos oito auxiliares da escrita a quem compete atender o público. Atrás dela, igualmente centrada em relação ao eixo mediano que, partindo da porta, se perde lá no fundo, nos confins escuros do edifício, há uma linha de quatro mesas. Estas pertencem aos oficiais. A seguir a eles, vêem-se os subchefes, e estes são dois. Finalmente, isolado, sozinho, como tinha de ser, o conservador, a quem chamam chefe no trato cotidiano (...) $(T N, 1997$, p. 12)

Neste caso, usando a terminologia do próprio Foucault, o ato de "ver" corresponde a uma forma de "poder" e significa "vigiar". Estrategicamente, a mesa do conservador situa-se num ponto em que lhe é possível examinar o comportamento dos subalternos, sem, no entanto, ser visto por nenhum deles, exatamente como no desenho de prisão feito por Bentham. Foucault refere-se a esse olhar como "um olhar centralizado", mas distanciado das pessoas vigiadas (para evitar contatos de algum modo danosos ao poder vigilante, como os contágios, no caso dos espaços hospitalares).

A necessidade de fiscalização simultânea de um grande número de pessoas justifica que a invenção do sistema óptico de Jeremy Bentham, no final do século XVIII, tenha passado pela mudança nos projetos e finalidades da arquitetura, que começa a ser utilizada para fins econômico-políticos, ou seja, torna-se um modo de organização política (FOUCAULT, 1979, p.211). A respeito desta questão de visibilidade, Foucault ainda estabelece um ponto de aproximação e outro de contraposição entre Rousseau e Bentham, os quais seria importante mencionar neste momento, pois ambos defendem a construção de uma "sociedade transparente", em que a visibilidade ocupe um lugar de destaque. No entanto, a função e a finalidade da visibilidade são diferentes para cada um deles. 
Enquanto o pensamento de Rousseau se volta para a perda das fronteiras e para o fim das desigualdades sociais (constituindo-se, portanto, em pensamento revolucionário), Bentham arquiteta "uma visibilidade organizada inteiramente em torno de um olhar dominador e vigilante. Ele faz funcionar o projeto de uma visibilidade universal, que agiria em proveito de um poder rigoroso e meticuloso.” (Id, p.215)

O final da comparação que Foucault estabelece a respeito de ambos, pela sua importância, também merece ser mencionado. Segundo ele, para Rousseau cada vigia (como o preceptor de Émile) seria um camarada; já para Bentham, cada camarada seria um vigia. (p.215). Em Todos os Nomes, o comportamento vigilante e repressor, representativo do poder de sanção que é delegado aos colegas, pode ser visto quando o Sr. José chega atrasado ao trabalho e com a barba por fazer:

(...) Acordou tarde, quase à hora de abrir a Conservatória, não teve sequer tempo de fazer a barba, vestiu-se de atropelo e saiu de casa em desatinada correria, imprópria a sua idade e da sua condição. Todos os funcionários, desde os oito auxiliares de escrita aos dois subchefes, se encontravam sentados, de olhos fixos no relógio da parede, à espera de que o ponteiro dos minutos se sobrepusesse exactamente ao número doze. O Sr. José dirigiu-se ao oficial do seu lado, a quem devia dar as primeiras explicações, e pediu desculpa pelo atraso, Dormi mal, justificou-se, embora sabendo, pela experiência de muitos anos, que uma explicação como esta de nada serviria (...) $(T N$, p. 202)

Os itálicos não existem no texto do romance; foram colocados agora para deixar evidente, no texto, o olhar vigilante dos demais colegas do Sr. José. Estão igualmente visíveis no fragmento os traços de impessoalidade do ambiente, na medida em que os colegas não aparecem nomeados nem individualizados, mas em grupos despersonalizados: "todos os funcionários", "oito auxiliares de escrita", "dois subchefes", "o oficial do seu lado".

No mesmo episódio do fragmento transcrito acima, paralelamente ao ato de vigiar pode-se encontrar um outro gesto que lhe corresponde - o de punir, expresso no texto pela expectativa dos funcionários em relação à repreensão do Sr. José pelo 
conservador. E, em sociedades como a alegorizada em Todos os nomes, a punição, segundo Foucault, se dá pela palavra. Trata-se, explica Foucault a respeito do pensamento de Bentham, de um discurso "disciplinar", "preventivo", que constrangeria as pessoas a não fazerem o que quer que fosse nocivo. (In FOUCAULT, 1995, p. 215216). Um exemplo deste tipo de discurso pode ser encontrado no interrogatório do Sr. José, feito pelo conservador como forma de intimidá-lo a não agir de maneira inadequada no serviço burocrático:

(...) foi isso mesmo o que o conservador perguntou ao Sr. José, Está doente, julgo que não, senhor, Se não está doente, como explica então o mau trabalho que tem andado a fazer nos últimos dias, (...) Se os seus erros de serviço são causados pela insônia e se a insónia está a ser causada por acusações da consciência, então há que descobrir a falta cometida, (...) A consciência não me acusa, As consciências calam-se mais do que deviam, por isso é que se criaram as leis (...). (TN, p. 79).

Já foi dito no capítulo anterior que o poder, tal como concebido por Foucault, não existe enquanto substância autônoma, mas sim se executa, isto é, existe como prática nas relações de forças. Outro aspecto importante na concepção foucaultiana de poder é que ele não é apenas repressivo; ao contrário, contém em si uma dose de resistência que leva o sujeito a produzir. No entanto, Foucault também constata, no seu estudo sobre o sistema prisional, que as prisões modernas, ao invés de recuperarem criminosos, produzem um aumento no número de delinqüentes e um agravamento do tipo de crimes que são cometidos. Sobre a relação entre a prisão e o aumento da delinqüência, numa entrevista ao periódico francês Magazine Littéraire, Foucault afirma que: "Desde 1820 se constata que a prisão, longe de transformar os criminosos em gente honesta, serve apenas para fabricar novos criminosos ou para afundá-los ainda mais na criminalidade." Ao longo dessa mesma entrevista, Foucault ainda diz que o trabalho penal ensina apenas o "trabalho pelo trabalho", o "trabalho como virtude", o trabalho como um fim em si mesmo (in FONSECA, 2003, p.133) 
Este é o tipo de trabalho que os funcionários executam na Conservatória: trabalho mecânico, solitário, trabalho de copistas, enfim. Porém, a partir de um dado momento, o Sr. José deixará de exercer mecanicamente as suas funções e passará a dar os primeiros passos em direção à sua autonomia como sujeito. Para isso, (mais uma vez a ironia de Saramago está presente) ele passará da condição de observado à de observador. Ou, em outros termos, ele passará a praticar um outro modo de ver. Será o ato de ver, não para vigiar, mas para conhecer (e conhecer-se). Seu percurso terá um caráter epistemológico e ontológico, constituindo-se, portanto, como um percurso de busca de conhecimento e autoconhecimento. Será ainda em Bakhtin que poderão ser encontradas as pistas para a compreensão das mudanças que ocorrerão com o Sr. José.

Para a fenomenologia de Bakhtin, a visão também é um sentido importante, se não o mais importante, a porta principal de acesso à percepção do mundo. Katerina Clark e Michael Holquist dizem que, para o pensador russo, "ver é perceber e perceber é ser" (1998, p.93) ou "estar consciente significa ver algo". Mas, explicam os mesmos comentadores, há a ressalva de que o que se vê depende do lugar a partir do qual este determinado aspecto da realidade é visto. Trata-se da lei da localização, que Bakhtin formulou com base na lei da relatividade de Einstein, porém, na sua valorização do processo ininterrupto de construção do self, Bakhtin colocou em destaque não aquilo que não podia ser visto, mas sim o que ele chamou de "excedente do ver": "o excedente do meu ver corresponde àquilo que só eu e mais ninguém é capaz de ver”. (CLARK e HOLQUIST, 1998, p.94-95)

O conceito de outridade, também fundamental no pensamento de Bakhtin, precisa ser trazido para este contexto para que se entenda melhor a dimensão da lei de localização formulada pelo autor. Isso porque, quando essa lei foi formulada, Bakhtin estava pensando relacionalmente, isto é, estava levando em consideração o que eu posso 
ver porque me situo neste locus e não em outro, e o que o outro não pode ver porque não pode estar, simultaneamente, no mesmo lugar que eu. Para ele, isso faz toda a diferença na constituição que eu faço de mim como sujeito. A título de esclarecimento, segue a explicação dada por Clark e Holquist a este respeito. Apesar de extensa, convém transcrevê-la:

\footnotetext{
Para Bakhtin, o sistema de referência que gerou o efeito de simultaneidade devia encontrar-se na mecânica das transformações self outro, especificamente na lei da localização. Você pode ver as coisas às minhas costas, como uma pintura ou nuvens que passam, mas estão ocultas à minha visão, enquanto eu posso ver coisas das quais você, de sua localização, não tem visão, como uma pintura diferente em outra parede ou outras nuvens que se movem por trás de sua cabeça. Esta diferença determina que, embora estejamos no mesmo evento, ele é diferente para um e para outro (p.95)

A outridade não é, pois, um a priori metafísico, porquanto a não-coincidência é um traço constitutivo da percepção humana. Há também um hiato estrutural na visão de que o homem é dotado, um ponto cego ditado pela lei da localização. Mas, uma vez que o lugar ocupado por cada um de nós é único, tanto as coisas que não posso ver quanto aquelas que posso são distintivas em relação a mim mesmo e ajudam de diferentes e importantes maneiras a constituir-me. (Id.)
}

Da primeira citação, é importante reter a expressão "sistema de referências", que traz em seu bojo o sentido da relação diádica fundamental no pensamento de Bakhtin: a relação entre o eu e o outro, da qual emerge o meu self: "O outro é, no sentido mais profundo, meu amigo, porque é somente do outro que eu posso obter o meu self." (p.91) Da segunda, deve-se abstrair a indissolúvel ligação entre o eu e o outro, condição sine qua non para minha constituição como sujeito.

Estas informações teóricas preliminares podem contribuir para dar consistência a uma possível leitura de certas atitudes do Sr. José. Trata-se dos delitos que ele passa a cometer a partir do momento em que, sem razão aparente, sente um desejo de procurar mais dados sobre a figura do bispo à qual não tinha a menor identificação, apenas como uma forma de ocupar o seu tempo ocioso, que, aliás, era preenchido de forma rigorosa, com o mesmo rigor com que exercia o seu trabalho como auxiliar de escrita da 
Conservatória. A sua coleção consistia num trabalho mecânico de seleção de recortes de jornais e revistas e de cópia. O narrador, a esse respeito, comenta que o seu José parecia entediado com a sua coleção de famosos. Talvez por este motivo ele tenha resolvido entrar na Conservatória pela porta de comunicação com a sua moradia para tentar encontrar informações mais instigantes do que as veiculadas pela mídia.

Por exemplo, a atribuição do nome de "crime” à seqüência de gestos do Sr. José tem um conteúdo axiológico atrelado a um lugar a partir de onde são avaliadas as suas atitudes. A referência, o lugar de onde emana essa avaliação, é o poder instituído; é, portanto, sob a óptica da Conservatória e de suas normas disciplinares que o gesto do protagonista é um delito (assim como o é o desejo que dá origem às sucessivas transgressões). Alguns detalhes da narrativa deixam evidente que o protagonista faz $o$ mesmo julgamento do seu ato, o que leva a crer que o sistema de valores do poder dominante está enraizado no seu inconsciente, comprovando, então, o seu assujeitamento Esta condição do Sr. José possibilita compreender seu drama de consciência, os remorsos que sente quando comete as primeiras infrações. Veja-se um exemplo:

(...) Imagine agora quem puder o estado de nervos, a excitação com que o Sr. José abriu pela primeira vez a porta proibida, o calafrio que o fez deter-se à entrada, como se tivesse posto o pé no limiar duma câmara onde se encontrasse sepultado um deus cujo poder, ao contrário do que é tradicional, não lhe adviesse da ressurreição, mas de tê-la recusado (...). (TN, p. 26)

Ou então este outro, bastante significativo do inquérito a que Sr. José imagina ser submetido caso viessem a descobrir suas atividades de investigador:

(...) À pergunta, Que andava você a fazer nesse dia, poderia dar ele uma resposta praticamente imediata, bastar-lhe-ia ir consultar o calendário (...) Relacione agora com a sua actividade de investigador e diga-me quando foi isso, então já teria de ir consultar o caderno de apontamentos que guardava debaixo do colchão Foi dois dias depois do meu assalto ao colégio, responderia. De facto, tomando como boa a data do óbito inscrita no verbete 
com o seu nome, a mulher desconhecida tinha morrido dois dias depois do deplorável episódio que transformou em delinqüente o até aí honesto Sr. José (...) $(T N$, p. 180)

O fato de se tratar de um monólogo interior deixa bem nítido o sentimento de culpa e de perseguição do Sr. José, sentimento que provém da interiorização da necessidade de obediência ao deus referido no primeiro exemplo e do pecado que consiste a transgressão a tal norma.

Mas é interessante examinar as atitudes que o Sr. José toma em certos pontos visitados durante as suas investigações. Por exemplo, ele se senta à mesa do conservador quando, na primeira transgressão, "invade" a Conservatória para fazer sua pesquisa sobre o bispo; quando "invade" a escola onde a mulher desconhecida havia estudado, ele se senta no sofá da sala do diretor (e, mais tarde, quando volta lá uma segunda vez, descobre que aquele era o lugar onde o diretor costumava sentar-se). Ou seja, nos dois casos não se poderia conjeturar que o Sr. José estaria "experimentando" outra referência, outro ponto a partir do qual pudesse conhecer o mundo, tomar consciência dele, de si e de si em relação a ele?

No inicio, o protagonista sente-se um usurpador do lugar do outro, seja esse outro o conservador, seja o diretor da escola, seja mesmo a presença/ausência da figura da mulher desconhecida. Porém, à medida que o tempo vai passando o Sr. José vai se sentindo mais confiante e vai assumindo uma posição mais confortável no lugar do outro. As trocas de posição que se dão entre os sujeitos (especialmente entre o Sr. José e o conservador) vão contribuir para uma mudança na perspectiva e uma representação figurativizada da concepção einsteiniana da não-coincidência e da ilusão de simultaneidade.

No caso da ida do Sr. José à casa da mulher desconhecida, após ter sabido da notícia da sua morte, pode-se considerar esse momento como de extrema simbologia 
ritualística, pois parece estar havendo, então, uma efetiva comunhão, um encontro do Sr. José com a mulher desconhecida, por meio de todos os objetos da sua casa, que, na verdade, a significam.

Mas estes aspectos, que fazem parte do percurso iniciático do Sr. José, serão tratados mais detidamente no próximo capítulo, que versa sobre as relações do protagonista e do seu duplo, o conservador, ao longo dessa busca de autoconsciência. 


\title{
3. O herói (e seu duplo) em busca de si mesmo e do outro.
}

\author{
"Só se nos detivermos a pensar nas pequenas coisas \\ chegaremos a compreender as grandes." \\ José Saramago.
}

\subsection{A autoconsciência do Sr. José}

"O romance valoriza a busca, não a posse dos objetos desejados e procurados, [pois] se ao fim da vida tivermos as mãos vazias, outros continuarão a procura (...)" (1998, p.16). Estas são palavras de Beatriz Berrini acerca do movimento do protagonista em Todos os Nomes. De fato, o romance aponta insistentemente para a necessidade de não interromper ou terminar a busca, de não encurtar caminhos ou encontrar respostas, numa associação entre a atividade de busca e o sentido processual da existência.

De fato, o traçado labiríntico do caminho tem a ver com o próprio caráter existencial desta procura. Aliás, o protagonista, em sua conversa com a senhora do résdo-chão direito, já manifestou sua intenção de seguir o caminho mais longo. Isto porque, por trás desta busca, há um processo de aprendizado que demanda tempo para que se realize. Um elemento importante que integra esse processo de aprendizagem reside nos diálogos que ele estabelece, seja com a senhora do rés-do-chão direito, seja com o enfermeiro, com o farmacêutico, com o "teto do seu quarto", com a voz da sua consciência, com a senhora do rés-do-chão direito pela segunda vez, com o auxiliar do Cemitério, com o pastor, com o teto do seu quarto de novo, com os pais da desconhecida, com o "diretor da escola" em que a desconhecida tinha estudado e depois 
lecionado e, finalmente, com o conservador - todas essas interações contribuem para a construção da sua autoconsciência.

Basicamente, o trajeto percorrido pelo Sr. José inclui: saída da Conservatória, chegada à antiga morada da mulher desconhecida, retorno à Conservatória, ida à casa da senhora do rés-do-chão direito; retorno à Conservatória, invasão do colégio (com permanência prolongada), volta à Conservatória, retorno à casa da senhora do rés-dochão direito, volta à Conservatória, Ida ao Cemitério (com permanência prolongada), retorno à Conservatória, ida à casa dos pais da desconhecida, volta à Conservatória; retorno ao Colégio; ida à casa da mulher desconhecida e, finalmente, retorno à Conservatória.

Portanto, o protagonista de Todos os nomes só irá concluir a sua busca após percorrer e superar todos os labirintos, tanto os de ordem física, como a Conservatória, a Escola e o Cemitério, como os de ordem mental: seus pensamentos, impasses, inseguranças e medos. Em A estética do labirinto, a autora Lúcia Leão faz uma síntese das três etapas constituintes da caminhada no labirinto: a purgação, a realização e a liberação. Na fase da "Purgação", é necessário que o peregrino se livre de tudo que possa corromper o seu pensamento - "as precauções" e os "medos" - para que ele consiga se desprender das coisas mundanas; na "realização", também chamada de fase do "desprendimento", ocorrem as práticas que gerarão mudanças no ser do indivíduo; trata-se da fase da trajetória correspondente ao "momento em que Teseu matou o minotauro; na liberação corresponde à fase da saída do labirinto, há o reencontro com a vida exterior, e é nesta fase que o caminhante sai do labirinto, transformado" (LEÃO, 2002, p. 160).

A busca do protagonista dar-se-á primeiramente dentro do prédio da Conservatória, pois a sua relação com o mundo até aquele momento era mediada pelos 
arquivos. Porém, à medida que vai lidando com as limitações dos registros, ele partirá em busca de informações reais, que transcendem os muros da Conservatória.

Esta relação do Sr. José com a Conservatória pode ser interpretada de várias formas. Uma delas prende-se ao seu relacionamento com o espaço labiríntico dos arquivos - como um grande túmulo, onde são depositados os arquivos de todos os nomes tanto dos vivos quanto dos mortos.

Francisco M. Silveira, em sua obra Saramago: - Eu próprio, o outro?, faz uma leitura junguiana do espaço da Conservatória, que, no romance, pode ser vista como um grande depósito de arquivos. Para ele, tais arquivos podem ser interpretados como as "personae" dos indivíduos, isto é, as máscaras sociais de que todos se revestem no trato cotidiano com a sociedade em que vivem. Através desta máscara as pessoas são aceitas socialmente.

De acordo com as observações do autor, o espaço da Conservatória Geral é retratado no romance saramaguiano "como todo cartório, de um arquivo ou catálogo de "personae". Ali só se registram, do ente que cada um de nós é, nomes, sobrenomes, datas de nascimento e morte, averbamentos de casamento, divórcio, óbito" (SILVEIRA, 2007, p. 56).

Ainda segundo ele, “à Conservatória Geral do Registro Civil só interessa saber, fazendo coro à epigrafe de Todos os nomes, o nome que nos deram, não o nome que temos $[\ldots]$, só interessa à massificação e anonimato do Cartório Social a inautenticidade de nossa existência legal de "ser-no-mundo". Que se lixe e se esqueça a realidade de nossa existência como entes" (Id., p. 57).

Assim, com base nessa leitura interpretativa, é possível considerar que o que o Sr. José procura, no início da sua busca, é um sentido para a impessoalidade reinante nas relações desumanas da Conservatória. Pois a sua vida resume-se nesse espaço, pelo 
menos até ele encontrar o verbete "mágico" que irá mudar a sua forma de agir e de pensar sobre o mundo, inclusive sobre a própria Conservatória e das relações de poder nela existentes.

A decisão do Sr. José de sair do labirinto da Conservatória em busca de relações dialógicas acontecerá de forma paulatina. Como uma criança que sai do útero para a vida externa, o protagonista apresenta muitas dificuldades em aprender a tratar diretamente com situações tipicamente urbanas como a abordagem de pessoas, como se nunca o tivesse feito fora do ambiente de trabalho. O Sr. José sente-se, no início da sua procura, como um pássaro fora do ninho, como se estivesse com receio de dar os primeiros passos. Mesmo assim, traça um itinerário e, daí em diante, o ritmo da narrativa vai-se acelerando, ao mesmo tempo que o Sr. José vai adquirindo autoconhecimento.

A trajetória do Sr. José em busca da desconhecida também compreenderá duas etapas - a primeira realiza-se antes da morte dela, ou mesmo, antes da tomada de consciência dele sobre o fato, e a segunda se inicia com a notícia da morte, em direção à vida, ou seja, trilhando o caminho inverso. O itinerário percorrido assemelha-se a um labirinto, assim como o são a Conservatória, a Cidade, a Escola e o Cemitério. Ao sentir-se atraído por desvendar o misterioso verbete da desconhecida, ele percorrerá um longo caminho até chegar ao túmulo e descobrir que ela havia desaparecido novamente, a partir das revelações do pastor. Daí o protagonista irá reiniciar outra busca, não mais pela pessoa que achava poder encontrar, mas pelas causas ou razões da sua morte. Para isto, ele terá que percorrer labirintos externos à Conservatória, tais como o colégio onde a desconhecida havia estudado e depois passou a lecionar e o Cemitério, onde também procura o local em que a desconhecida tinha sido enterrada. 
Na primeira etapa do percurso, seu nível de autoconsciência é incipiente, quase nulo, como se pode ver pelo trecho em que o Sr. José é submetido a um interrogatório pelo narrador saramaguiano sobre as razões que o teriam levado a procurar pela desconhecida. A passagem evidencia a indecisão do protagonista, que parece querer se esquivar da responsabilidade de ter tomado a decisão de sair em busca de uma mulher anônima como ele. Desta forma, ele procura justificar-se, alegando que foi obra do acaso, que ele apenas foi levado a procurar pela desconhecida. Ao mesmo tempo, o narrador interfere levantando questões controversas sobre as responsabilidades de cada um como indivíduos autônomos, portanto com livre arbítrio para tomar as próprias decisões:

(...) se persistíssemos em afirmar que as nossas decisões somos nós que a tomamos, então teríamos de principiar por dilucidar, por discernir, por distinguir, quem é, em nós, aquele que tomou a decisão e aquele que depois irá cumprir, operações impossíveis, onde as houver. Em rigor não tomamos decisões, são as decisões que nos tomam a nós. [...] É por estas razões que o Sr. José, mesmo que o submetessem ao mais apertado dos interrogatórios, não saberia dizer como e porquê o tomou a decisão,[...] a explicação que daria, Só sei que foi na noite de quarta-feira, estava eu em casa, de tão cansado que me sentia nem tinha querido jantar, ainda tinha a cabeça a roda de ter levado todo o santo dia em cima daquela escada, o chefe devia compreender que já não tenho idade para essas acrobacias, que não sou nenhum rapaz, além do padecimento, Que padecimentos, Sofro de tonturas, vertigens, atração do abismo, ou como quer que lhe queiram, Nunca se queixou, Não gosto de me queixar, É bonito da sua parte, continue, Estava a pensar em meter-me na cama, minto, até já tinha descalçado os sapatos, quando de repente tomei a decisão. Se tomou a decisão, sabe por que a tomou, Acho que não a tomei eu, que foi ela a tomar-me a $\operatorname{mim}(\ldots)(T N$, p. 42$)$

Neste trecho, percebe-se, pela forma como o narrador se refere aos motivos que teriam levado o Sr. José a decidir buscar pela mulher anônima, que ele não saberia responder, pois assim como o verbete aparece na vida do Sr. José como obra do acaso, ao vir grudado na ficha do bispo, também a sua decisão de procurar pela mulher é 
justificada pelo narrador como algo para cuja decisão o protagonista desconhece o motivo: "Acho que não a tomei eu, que foi ela a tomar-me a mim." (TN, p.42).

Acredita-se que esta forma de o Sr. José tentar justificar a sua iniciativa em procurar pela mulher desconhecida, prende-se à sua própria condição de iniciante no seu processo de aprendizagem - é como se ele ainda não tivesse consciência do real motivo da sua decisão. Esta consciência só virá com o tempo, com a aprendizagem por meio dos diálogos que estabelece com outras pessoas, os quais nesta fase da narrativa ainda não começaram. O Sr. José, até este momento, só conseguiu usar a chave da porta de comunicação da sua casa com a Conservatória, em busca de informações para as celebridades da sua coleção.

Em outros momentos, o Sr. José será visto se queixando por causa dos malabarismos que é obrigado a fazer em cima de uma escada para alcançar alguns verbetes nos arquivos dos vivos. Nessas queixas fica evidente o desinteresse com que o auxiliar de escrita exerce o seu ofício, e o quanto o incomoda ter que fazer esforços que ele julga naquele momento estarem acima de sua capacidade. Porém, como se verá mais adiante, ele não medirá esforços nem se queixará no momento em que invade o colégio em que a desconhecida havia estudado e lecionado (como ele fica sabendo depois).

$\mathrm{Na}$ realidade existe uma grande diferença entre a busca que o Sr. José empreende pela mulher desconhecida e a sua atividade como auxiliar de escrita na Conservatória. No primeiro caso, o protagonista é movido por um desejo, enquanto no segundo a sua relação é destituída de qualquer sentido. Parafraseando o narrador saramaguiano no episódio do interrogatório, se perguntassem ao Sr. José sobre o sentido de ele trabalhar na Conservatória, ele provavelmente responderia, pelo menos até certo momento, que não sabia dizer o porquê. Que ele apenas fazia o que lhe mandavam e, 
portanto, para fazer aquilo que fazia não era preciso e nem recomendável atribuir sentido.

Já os primeiros passos da investigação do Sr. José são cheios de entusiasmo. Primeiramente, ele manterá uma relação de observador ao decidir sair para conhecer o local onde a desconhecida tinha morado. Este será o seu primeiro contato com o mundo exterior à Conservatória. Ao chegar lá, ele apenas ficará olhando, como se estivesse entusiasmado com a descoberta. O narrador se refere à atitude do Sr. José como típica de alguém que estivesse deslumbrado em poder ver de perto algo que, aos poucos, vai tomando como seu: (...) O prédio estava lá, havia luz nas janelas (...) Fiquei ali uns minutos (...) Só a olhar, Sim senhor, só a olhar (...) (TN, p.42-43).

A impressão que se tem é a de alguém que acabou de sair do útero materno e começa a familiarizar-se com algo que nunca tinha visto, uma construção diferente daquela em que estava situada a Conservatória e da sua casa acoplada a esta. O Sr. José reage a sua primeira saída da Conservatória como alguém que até então parecera cego e que está recuperando a visão ou treinando um sentido que parecia ter um uso limitado no seu local de trabalho. Na Conservatória a sua visão deveria fixar-se no Conservador ou no seu próprio trabalho e na realização da sua coleção; ele apenas deveria concentrar-se nas notícias e fotos de jornais e revistas e, quando estava a mexer nos arquivos, mantinha com estes uma relação estritamente virtual. Portanto, este deslumbramento expresso pelo Sr. José é típico de alguém que olha pela primeira vez para algo real e, ao mesmo tempo, diferente daquilo que, até então, estava acostumado a enxergar.

Aliás, é tão forte a sua motivação pela busca da identidade da mulher desconhecida que dá para compreendê-la como "o fio" que o orienta na busca pelo 
sentido da vida, do mesmo modo que o fio/barbante lhe é essencial para a movimentação no interior da Conservatória.

O Cemitério constitui um outro espaço labiríntico que integra este percurso do Sr. José. Caracterizado de forma semelhante à Conservatória, o seu traçado espacial é comparado a um polvo com inúmeros tentáculos, como se estivesse a se apossar da cidade. O narrador esclarece que não há fronteiras entre o cemitério e a cidade, ou seja, mortos e vivos dividem o mesmo espaço, assim como ocorrerá na Conservatória, onde os verbetes dos vivos e dos mortos não serão mais separados, seguindo a última determinação do conservador:

(...) Da mesma maneira que a Conservatória do Registo Civil [...] a escrita não escrita deste Cemitério Geral é Todos os Nomes, embora deva reconhecer-se que, na realidade, à Conservatória é que estas três palavras assentam como uma luva, porquanto é nela que todos os nomes efectivamente se encontram, tanto os dos mortos como os dos vivos, ao passo que o Cemitério, pela sua própria natureza de último destino e último depósito, terá de contentar-se sempre com o nome dos finados (...) as relações entre os funcionários da Conservatória e do Cemitério são claramente amistosas, de mútuo respeito, porque, no fundo, além da colaboração institucional a que estão obrigados pela comunidade formal e contigüidade objectiva dos seus respectivos estatutos, sabem que andam a cavar nos dois extremos da mesma vinha, esta que se chama vida e está situada entre o nada e o nada.(...) (TN, p. 217-218)

Na conversa com o "auxiliar de escrita" do Cemitério, o Sr. José fica sabendo que a mulher desconhecida estava na ala dos suicidas, que o Cemitério é um labirinto, só que de "linhas rectas" e, neste sentido diferente, da Conservatória, onde não há "linhas rectas". Além disso, este lhe prestou um grande serviço em orientá-lo através do mapa até o caminho para se chegar até a sepultura da desconhecida, o que faz o Sr. José perguntar-lhe pelo motivo que o teria levado a achar que pretendia visitar a sepultura da mulher, ao que o funcionário responde: (...) Nada, talvez porque eu teria feito o mesmo se estivesse no seu lugar, Porquê, Para ter a certeza, De que está morta, Não, a certeza de que esteve viva (...) (TN, p.224) 
Percebe-se, neste diálogo, uma antecipação do que irá ocorrer após o Sr. José descobrir que a numeração do túmulo da desconhecida havia sido trocada, acontecimento que irá gerar uma enorme confusão quanto à própria existência da mulher anônima. Durante a sua caminhada pelo Cemitério, o Sr. José irá aos poucos desvendando o caminho da ala dos suicidas, observando pequenos detalhes descritos pelo narrador de forma detalhada:

(...) Orientando-se pelo mapa, porém algumas vezes lamentando a falta duma bússola, o Sr. José caminha na direção do sector dos suicidas onde está enterrada a mulher do verbete, mas o seu passo é agora menos rápido, menos decidido, de vez em quando detém-se a contemplar um pormenor escultórico (...) Numa clareira, o Sr. José encontrou o que procurava. Não tirou da algibeira o papel que o auxiliar de escrita do Cemitério lhe havia dado, não fizera qualquer esforço para fixar o número tinha-o diante de si, iluminado em cheio, como se tivesse sido pintado com tinta fosforescente. Está aqui disse. (...) (TN, p. 230-231)

O narrador refere-se ao passo mais lento do Sr. José, como se este estivesse naquele momento convicto de que a sua busca estava chegando ao fim e de que já não precisava apressar-se tanto. Constata-se, aqui, a relativa facilidade com que o Sr. José locomove-se pelo labirinto do Cemitério. Ao contrário do que ocorria na Conservatória, o Sr. José não precisa de lanterna nem fio, pois não há como se perder. E, mesmo que isto venha a acontecer, não existem muros neste local, ou seja, não há separação entre as ruas da cidade e do Cemitério, pois as passagens são interligadas, o que permite aos visitantes do Cemitério tomarem o rumo da cidade, ou vice-versa, os transeuntes podem entrar no Cemitério, quando quiserem. Além de tudo, o Sr. José percorre as trilhas do Cemitério com a ajuda de luzes naturais, como a do sol e a da lua, o que impede de ele perder-se na escuridão.

Depois de passar a noite ao lado do túmulo da mulher desconhecida, ao amanhecer, o protagonista encontra o pastor de ovelhas. Esta personagem é 
caracterizada de forma enigmática e faz alusão ao pastor de outra obra saramaguiana O Evangelho segundo Jesus Cristo. Tanto neste romance quanto no romance ora estudado, a figura do pastor é retratada como transgressora, ao adotar posturas tidas como contrárias à ordem vigente, além disso, os seus ensinamentos transmitem sabedoria, constituindo uma figura central no processo de autoconsciência do herói saramaguiano.

Como ocorre em O Evangelho segundo Jesus Cristo, o diálogo entre o pastor e o Sr. José se dá em meio a um nevoeiro que encobre a ambos. O pastor irá confidenciarlhe o segredo do "talhão dos suicidas" e confessar que se encarrega de trocar os números de todos os túmulos desta ala antes de serem coladas as "placas de mármore" com os nomes, por acreditar que as pessoas aí enterradas não queriam ser encontradas.

Essa revelação se constituirá no novo marco para o reinício da busca do Sr. José, pois a mulher anônima que ele pensava ter encontrado, tinha acabado de se perder. Esta nova etapa da procura do Sr. José, diferentemente da primeira fase do romance (em que a busca gira ao redor da busca de uma mulher ainda viva), terá como ponto de partida a morte, pois o pastor acaba de lhe revelar que trocara o número das sepulturas e que, portanto, aquela não era a sepultura da mulher desconhecida. Percebe-se na fala do pastor a referência ao Cemitério como um labirinto "que não pode ser visto de fora", ou seja, pelos olhos dos visitantes, pois somente ele, na condição de autor da prática de efetuar as trocas das numerações dos túmulos, conhece o segredo que agora revela ao Sr. José:

(...) Qual é então a verdade do talhão dos suicidas, perguntou o Sr. José, Que neste lugar nem tudo o que é parece, É um Cemitério, é o Cemitério Geral, É um labirinto, os labirintos podem ver-se de fora, Nem todos, este pertence aos invisíveis, Não compreendo, Por exemplo, a pessoa que está aqui disse o pastor tocando com a ponta no montículo de terra, não é aquela que você julga. De repente, o chão pôs-se a oscilar debaixo dos pés do Sr. José, a última pedra do tabuleiro, a sua derradeira certeza a mulher desconhecida enfim encontrada, tinha acabado de desaparecer (...). (TN, p. 239) 
Depois da revelação, o Sr. José, identificado com o pastor, como se houvesse aqui um outro caso de espelhamento (como o que ocorre entre ele e o conservador), comporta-se de maneira semelhante ao trocar a numeração da sepultura, por achar que, desta maneira, poderia quem sabe estar colaborando para que o pastor, ao fazer o mesmo, devolvesse a sepultura da desconhecida à sua numeração correta. Neste trecho, ao adotar uma postura similar à do pastor, tem-se mais uma demonstração da rebeldia do Sr. José, como se estivesse a praticar uma inversão, fazendo a mentira virar verdade e vice-versa:

(...) A troca estava feita, a verdade tinha-se tornado mentira. Em todo o caso, bem poderá vir a suceder que o pastor, amanhã, encontrando ali uma nova sepultura, leve, sem saber, o número falso que nela se vê para a sepultura da mulher desconhecida, hipótese irônica em que a mentira, parecendo estar a repetir-se a si mesma, tornaria a ser verdade. As obras do acaso são infinitas (...) $(T N, \mathrm{p} .243)$

No processo de autoconsciência do Sr. José merece destaque, como interlocutor, a personagem "fantástica" do "tecto". Pode-se conceber esta voz como um tipo de interferência do narrador, principalmente nas passagens em que ele se anuncia como o “olho de Deus". Pela sua localização, ele assume o papel vigilante de todos os passos do protagonista, tanto dos que já foram dados quanto dos que ainda estão por vir:

(...) Pelo menos há três pessoas, Quem são, perguntou o Sr. José, Os pais e o ex-marido, ao princípio cheguei a pensar nisso, mas resolvi deixar para outra ocasião, Ou o fazes agora, ou nunca mais, por enquanto ainda te podes divertir a andar um bocado mais de caminho, antes de bateres com o nariz no muro (...) $\mathrm{O}$ ex-marido, provavelmente será ele a pessoa que mais coisas poderá contar-te acerca dessa tua mulher desconhecida (...) imagino que não deva haver reserva ou segredo capazes de resistir por muito tempo ao microscópio duma observação contínua, Há quem diga, pelo contrário, que quanto mais se olha menos se vê (...) Tens medo de que ele se ponha a falar das causas do divórcio, não queres ter de ouvir nada que vá em desabono dela (...) o mais certo seria ele contar-me o caso de modo a ficar com a razão toda (...) De facto, estúpido não o és, o que levas é demasiado tempo a perceber as coisas, sobretudo as mais simples, Por exemplo, Que não tinhas nenhum motivo para ires a procura dessa mulher, a não ser, A não ser, quê, A não ser o amor. É preciso ser-se tecto para ter uma idéia tão absurda, Creio ter-te dito alguma vez que os tectos das casas são o olho múltiplo de Deus (...) Então diz-me também como poderia eu gostar de uma mulher a quem não conhecia, 
a quem nunca tinha visto (...) É indiferente que tenha cabeça ou tenha pés, falo-te doutra parte do corpo, do coração, esse que vocês dizem ser o motor e a sede dos afectos (...) Querias vê-la, querias conhecê-la, e isso, concordes ou não, já era gostar , Fantasias de tecto, Fantasias tuas, de homem (...) a grande diferença que há entre nós é que tu só me dás atenção quando precisas de conselhos e levantas o olho para cima, ao passo que eu levo o tempo todo a olhar para ti, O olho de Deus, Tome as minhas metáforas a sério, se quiseres, mas não as repitas como se fossem tuas (...) (TN, p. 248)

O que chama a atenção neste diálogo é o uso da expressão "olhos múltiplos de Deus" para referir-se aos tetos das casas. Assim como estes estão sempre a olhar para os moradores e visitantes do espaço, também o conservador é visto como um Deus omnisciente, ao acompanhar a trajetória do Sr. José. Ao tentar explicar a busca do Sr. José como movida pelo amor, acredita-se que esta justificativa endossa aquela defendida por Francisco M. Silveira, de que esta mulher faz o papel de anima do Sr. José.

Depois deste diálogo, o Sr. José resolve visitar os pais da desconhecida, porém antes de sair de casa, num dia de domingo, ele irá telefonar para a casa deles, na intenção de prepará-los para recebê-lo. Porém fica na dúvida quanto a usar o telefone da Conservatória, temendo que sua ligação seja descoberta. Neste trecho da narrativa já se constata certa indiferença do protagonista com relação às conseqüências que os seus atos podem acarretar, o que já indica, de certo modo, que tem convicção do que está fazendo.

Assim, neste estágio já é visível o grau de autoconsciência do protagonista e, como prova disso, tem-se a sua demonstração de indiferença em relação ao descobrimento das suas atividades irregulares (fato que pode ser enquadrado na categoria de revolta). Tão preocupado mostrava-se em resolver o seu impasse que nem se deu conta da presença do conservador, que tem um acesso de tosse por duas vezes dentro do prédio, como se quisesse anunciar a sua presença. 
A busca do Sr. José parece que vai chegando ao fim. Após a sua conversa com o teto do seu quarto, em que este lhe dará a idéia de visitar os pais e o ex-marido da mulher desconhecida, o narrador alerta para a proximidade do término da procura do protagonista, numa atitude de antecipação, muito recorrente neste romance:

(...) Os pensamentos do Sr. José já estavam lançados para a visita que ia fazer aos pais da mulher desconhecida, o último passo antes de bater com o nariz no muro, expressão igualmente metafórica que significa, Chegaste ao fim (...) (TN, p. 248)

O senhor José sente-se cada vez mais autoconfiante. Exemplo disso pode ser observado na sua postura de desobediência em relação aos regulamentos da Conservatória, ao usar o telefone em um domingo para tratar de assuntos relacionados à sua busca, sentar-se à mesa do conservador. Passa a comportar-se, enfim, como se fosse o verdadeiro "dono dos arquivos". Porém o seu domínio é de ordem simbólica, pois ele tornar-se-á o maior conhecedor dos arquivos:

(...) Pensa mesmo que tem uma fórmula capaz de dissipar logo de entrada qualquer desconfiança, que será dizer, como já está dizendo, sentado na cadeira do chefe, Fala do piquete da Conservatória Geral do Registo Civil, essa palavra piquete, julga ele, é a gazua que lhe abrirá todas as portas, e afinal não parecia ir fora da razão, do lado de lá estão a responder-lhe que sim senhor, venha quando quiser, hoje não saímos de casa. Um último vestígio de sensatez ainda fez perpassar pela cabeça do Sr. José o pensamento de que o mais provável era ter acabado de dar o nó na corda que o há - de enforcar, mas a loucura tranqüilizou-o, disse-lhe que a relação das chamadas irá tardar umas quantas semanas a ser enviadas pela central e que, quem sabe, até poderá suceder que o conservador se encontre de férias nessa altura (...) enquanto o pau vai e vem folgam as costas, murmurou o Sr. José, para concluir, resignado ao que dite o destino (...) uma vez que se tinha lembrado da credencial. Tornou a entrar na Conservatória foi ao armário dos impressos, mas tinha-se esquecido de que o armário dos impressos, desde o inquérito, estava sempre fechado. Pela primeira vez na sua vida de pessoa pacífica sentiu um ímpeto de fúria, a ponto de lhe passar pela cabeça dar um muro no vidro e mandar ao diabo as conseqüências. (...) O Sr. José envolveu a mão direita no lenço para não deixar o menor sinal de dedos que o denunciasse, agarrou na chave e abriu o armário dos impressos. Tirou uma folha de papel com o timbre da Conservatória, fechou o armário, foi repor a chave na gaveta do subchefe, nesse momento a fechadura da porta exterior do edifício rangeu, ouviu-se a lingueta a deslizar uma vez (...) quando a lingueta da fechadura acabou de correr por completo, já o Sr. José estava em casa ofegando, como se o coração lhe tivesse subido à boca. Um longo minuto passou até que do outro lado da porta se ouviu alguém tossir (...) Ouviu-se novamente a tosse, mais forte, talvez mais próxima, mas com a diferença de agora parecer 
deliberada, intencional, como se quem entrou estivesse a anunciar a sua presença. (...) (TN, p. 253)

Ao perceber a presença do conservador dentro da Conservatória, o Sr. José demonstra-se surpreso e ao mesmo tempo pasmado, porém mais adiante já manifesta certa segurança em relação aos seus atos, parecendo não temer as conseqüências deles. Agora, a sua autoconsciência parece alcançar o estágio de revolta e o medo já não é visível em suas ações. Percebe-se que o protagonista, ao mesmo tempo que se revolta contra o poder burocrático, adotando uma série de atitudes que o afrontam, mostra-se receoso e resignado em relação a esse mesmo poder:

(...) O Sr. José recuou devagar até a mesa, pegou na credencial e foi escondêla, assim como a folha tirada do armário, entre a roupa da cama, ainda desmanchada. Depois sentou-se e ficou à espera. Se lhe perguntassem o que esperava, não saberia responder (...) o Sr. José esperou mais um quarto de hora sem se mexer da cadeira. Ao fim desse tempo percebeu que tinha tomado uma decisão, não era somente seguir uma idéia fixa como de costume, tratava-se realmente de uma decisão, embora ele não soubesse explicar como a tomara. Disse em voz alta, O que tiver de acontecer, acontecerá, o medo não resolve nada (...) (TN, p. 253-254).

No início da citação o narrador faz uso do verbo "recuar", induzindo o leitor a pensar numa postura cautelosa do protagonista em relação as suas práticas ilícitas. No entanto, mais adiante, ele mostrar-se-á decidido em dar o passo que faltava para ir finalizando a sua procura, o que parece indicar uma atitude de revolta em relação ao estágio submisso em que se encontrava. Porém, deve-se lembrar da premissa a que já se fez referência neste trabalho, de que as categorias de autoconsciência não ocorrem de maneira estanque.

Ao encontrar-se com os pais da "mulher desconhecida", o Sr. José levou uma nova credencial com algumas alterações, já que a situação era de averiguação da causa 
do suicídio. O pai da desconhecida o interroga a respeito do tom da credencial que o Sr.

José tinha consigo:

(...) Deve ser importantíssima a sua missão para que se justifiquem um documento redigido nestes termos, É o estilo da Conservatória Geral, mesmo tratando-se de uma missão simples como esta, de investigação das causas de um suicídio, Parece-lhe pouco, Não me interprete mal, o que quis dizer é que qualquer que seja a missão de que nos encarreguem e em que se considere ser necessário levar credencial, é esse o estilo, Uma retórica da autoridade (...). (TN, p.255)

Nesta passagem, nota-se a atitude de resignação ao poder autoritário ao fazer uso dele para conquistar os seus objetivos, assim como uma atitude de rebeldia do protagonista ao falsificar outra credencial e alegar estar a serviço da Conservatória.

Diante do estranhamento dos pais da mulher desconhecida quanto à sua visita, o Sr. José justifica-se, alegando tratar-se se de uma pesquisa para se evitar que outras pessoas cometessem o mesmo ato, a partir do desvendamento dos motivos que levaram a desconhecida a suicidar-se. Para conseguir que os pais informassem tudo que sabiam sobre o suicídio da filha, o Sr. José apela para o "discurso autoritário" da credencial, que reproduz o discurso do conservador, demonstrando, desta maneira, apelar para o autoritarismo sempre que a situação exigir:

(...) Quando eu disse que precisava de falar com os senhores por razões de estatística, estava a simplificar a questão, Agora poderá explicar, Passou o tempo de nos contentarmos com os números, hoje em dia o que se pretende é conhecer, o mais completamente possível, o quadro psicológico em que se desenvolve o processo suicidário. Para quê, perguntou a mulher, se isso não restitui a vida à minha filha, A idéia é estabelecer parâmetros de intervenção. Não percebo, disse o homem. O Sr. José transpirava, o caso estava a sair-lhe mais complicado do que previra (...) O Sr. José (...) decidiu que tinha de mudar de táctica (...) Imaginem que a vossa filha não se suicidou ainda, imaginem que a investigação em que a Conservatória Geral do Registro Civil se encontra empenhada já tinha permitido definir certos conselhos e recomendações, capazes, eventualmente, desde que aplicados a tempo, de deter o que antes designei por processo suicidário, Foi a isso que chamou parâmetros de intervenção, perguntou o homem, Exactamente, disse o Sr. José, e sem dar tempo a outro comentário desferiu a primeira estocada, Se não pudemos impedir que a sua filha se suicidasse, talvez possamos, com a vossa colaboração e de outras pessoas em situação idêntica, evitar muitos desgostos e 
muitas lágrimas. A mulher chorava, murmurando, Minha querida filha, enquanto o homem secava os olhos passando por eles, com violência contida as costas da mão. O Sr. José esperava não ser obrigado a usar um último recurso, que seria, pensou, a leitura da credencial em voz alta e severa, palavra por palavra, como portas que sucessivamente fossem sendo fechadas, até deixarem uma única saída a quem estava a ouvir, cumprir imediatamente o dever de falar. (.,.) $\mathrm{O}$ homem dobrou a credencial e devolveu-a. Depois disse, Estamos à sua disposição (...) (TN, p. 256-257)

Nesta conversa com os pais da desconhecida, o Sr. José ficará sabendo que a mulher procurada era infeliz desde criança, como relata a sua mãe. No depoimento desta, o protagonista irá constatar ser impossível desvendar o mistério da morte da mulher, pois nenhuma pista é fornecida, o que levará o Sr. José a sugerir à mãe dela que lhe emprestasse as chaves da casa da sua filha, na esperança talvez de encontrar algum rastro, algo que lhe indicasse o que poderia ter causado tamanho desgosto a uma mulher jovem a ponto de apelar para o fim da sua existência. Verifica-se que a preocupação do Sr. José é de desvendar o mistério que ronda o suicídio da desconhecida por não se conformar com a inexistência de evidências que justifiquem este ato.

As perguntas feitas pelo Sr. José aos pais da desconhecida revelam a sua preocupação em desvendar a causa do suicídio da desconhecida. Na conversa transcrita a seguir, ele ficará sabendo que a desconhecida lecionara na mesma escola em que tinha estudado. Num determinado momento do interrogatório, os pais da moça revelam que a filha deles não era feliz no casamento, porém ela e o marido pareciam se gostar. Portanto, aparentemente nada explicava a conduta da desconhecida de tirar a própria vida. O que faz com que o Sr. José declare tratar-se de uma "estranha situação" e apelar para a autoridade da sua credencial para tentar propor uma visita à casa da mulher anônima, que o pai da moça recusa-se a acatar, diferentemente da mãe, que adota um procedimento curioso e, discretamente, entrega ao Sr. José as "chaves da casa da filha". Segue-se um trecho deste diálogo: 
(...) Mas devia haver papéis escritos, anotações, apontamentos, sempre os há, se me dessem autorização para passar os olhos por eles talvez se pudesse encontrar algo com interesse (...) o Sr. José desdobrou lentamente a credencial, olhou-a de alto a baixo como se estivesse a certificar-se dos poderes que inda poderia usar, depois disse, Se me permitissem ir lá, com a vossa presença, claro, Não, a resposta foi seca, cortante, A minha credencial, lembrou o Sr. José, A sua credencial contentar-se-á por agora com as informações que já leva, disse o homem (...) (TN, p. 259).

Na parte final da sua busca, o Sr. José demonstra tanta segurança em relação àquilo que se transformou em sua procura existencial, que passa a dar prioridade às suas atividades oficiosas. No trecho a seguir, fica claro que o protagonista mede as conseqüências da sua falta ao trabalho em plena segunda-feira, porém, mesmo assim, prosseguirá no seu intento de visitar a casa onde a mulher desconhecida morava, etapa em que finalmente irá concluir aquilo que ele, no seu íntimo, já sabe - a mulher desconhecida desapareceu assim como surgiu, repentinamente sem deixar qualquer vestígio:

(...) Após as sucessivas e cada vez mais graves irregularidades de comportamento cometidas desde que começara a procurar a mulher desconhecida, o Sr. José está consciente de que a falta ao serviço poderá converter-se na gota de água que entornará de vez o vaso da paciência do chefe. Esta ameaçadora perspectiva, porém não foi bastante para diminuir-lhe a firmeza da decisão. Por duas poderosas razões, aquilo que o Sr. José tem para fazer não pode ficar à espera de uma tarde livre. A primeira dessas razões é um destes dias vir a mãe da mulher desconhecida à Conservatória para recuperar as chaves, a segunda é que o colégio, como muito bem sabe o Sr. José (...) está fechado nos fins-de-semana. (...) (TN, p. 261-262)

O narrador refere-se à atitude do Sr. José de primeiramente ir ao colégio onde a desconhecida havia estudado e depois lecionado e, na seqüência, dirigir-se à casa onde ela tinha vivido. Na realidade, como já disse, o protagonista não tem pressa de terminar a sua busca, pois ela constitui o sentido da sua vida.

Ao encaminhar-se em direção ao colégio, o Sr. José pensava que a sua procura estava chegando ao fim e já estava a refletir sobre qual seria a sua próxima busca, se 
voltaria à sua coleção de famosos, porém não conseguia enxergar o sentido de retornar a sua busca de pessoas famosas, alegando que este status era passageiro, ficava se imaginando "a recortar notícias e fotografias com uma pilha de jornais e revistas ao lado, a intuir uma celebridade que despontava ou que pelo contrário fenecia, uma vez ou outra, no passado, tivera a visão antecipada do destino de certas pessoas que depois se tornaram importantes, uma vez ou outra tinha sido o primeiro a suspeitar que os louros deste homem ou daquela mulher iam começar a murchar, a encarquilhar-se, a cair em pó, Tudo acaba no lixo, disse o Sr. José, sem perceber naquele momento se estava a pensar nas famas perdidas ou na colecção”. (TN, p.264)

Neste momento, fica perceptível o amadurecimento da consciência do protagonista, ao se referir à insignificância da sua coleção de famosos e ao mostrar-se crítico e resistente a continuar o antigo hobby.

$\mathrm{Na}$ sua conversa com o diretor do colégio onde a desconhecida tinha estudado, o Sr. José vai constatando a inexistência de uma explicação evidente para o suicídio dela, o que faz pensar no que havia dito o pastor sobre o mistério que envolve os suicidas. $\mathrm{Na}$ transcrição seguinte, tem-se o diálogo entre o diretor e o Sr. José, no qual se percebe o gradual convencimento deste de que não houve um motivo evidente para a morte da mulher do verbete:

(...) É estranho, O que é estranho, Já falei com os pais, e tudo quanto da boca deles ouvi, mais o que estou a ouvir agora, parecem apontar a um suicídio sem explicação, Pergunto-me, disse o director, se o suicídio poderá ser explicado, Refere-se a este, Refiro-me ao suicídio em geral, Às vezes deixam cartas, o que não sei é se se poderá chamar explicação ao que nelas se diz, na vida não faltam coisas por explicar (...) Que explicação poderá ter, por exemplo, o que sucedeu aqui uns poucos dias antes do suicídio (...) os assaltos são geralmente fáceis de explicar, Excepto quando o assaltante sobe por um telheiro, entra por uma janela depois de partir a vidraça, anda pela casa toda, dorme no meu sofá, come do que encontra no frigorífico (...) e depois vai-se embora sem levar nada (...) agora diga-me se encontra para isto alguma explicação (...) Provavelmente tinha razão quando disse que talvez nenhum suicídio possa ser explicado, Racionalmente explicado, entenda-se, Tudo se passou como se ela não tivesse feito mais do que abrir uma porta e sair, Ou entrar, Sim, ou entrar, conforme o ponto de vista, Pois aí lhe fica 
uma excelente explicação, Era uma metáfora, A metáfora sempre foi a melhor forma de explicar as coisas (...) Quando o Sr. José já estava a descer o segundo lanço é que o diretor se lembrou de que não lhe havia perguntado como se chamava, Não tem importância, reconsiderou logo a seguir, é uma história terminada. (...) (TN, p. 266-267)

Neste diálogo constata-se o quanto a procura do Sr. José e o motivo do suicídio da desconhecida carecem de explicação racional. O Sr. José, pelo diálogo transcrito, parece ainda ter esperança de obter alguma informação que explique o ato, aparentemente sem fundamento, do suicídio da mulher desconhecida. Porém, o diretor afirma que existem coisas que não têm como serem explicadas de forma racional, como o suicídio e o assalto a sua escola, fazendo uma comparação entre eles. Diante de uma falta de explicação lógica, ele usa a metáfora para descrever o ato suicida- "Tudo se passou como se ela não tivesse feito mais do que abrir uma porta e sair”. (p. 266).

A história parecia terminada para o diretor da escola e para os pais da mulher desconhecida, mas o protagonista está convencido de que para ele ainda faltam duas etapas para finalizar a sua procura, ou pelo menos, para ele mesmo pôr um ponto na sua investigação:

(...) ainda lhe faltava dar o último passo, buscar e encontrar em casa da mulher desconhecida uma carta, um diário, um simples papel onde tivesse cabido o desabafo, o grito, o não- posso-mais que todo o suicida tem a estrita obrigação de deixar atrás de si antes de retirar-se por aquela porta, para os que ainda vão continuar deste lado possam tranqüilizar os alarmes da sua consciência (...) (TN, p. 267-268)

Agora falta o cumprimento das duas últimas etapas: a visita a casa onde a mulher desconhecida tinha morado e à casa da senhora do rés- do- chão direito. $\mathrm{Na}$ visita à casa da desconhecida é nítido o impasse do protagonista diante da sua ousadia em entrar na casa onde a mulher do verbete tinha morado e, ao mesmo tempo, a sua necessidade em se convencer de que a sua busca tinha chegado ao fim. Na citação 
seguinte percebemos na voz do narrador o perfil do Sr. José, o qual ao mesmo tempo em que deseja, "teme o que deseja”. Antes de seguir para o último lugar da sua busca e de retornar para a Conservatória, o narrador descreve a indecisão do Sr. José diante do seu passo final até a casa onde a desconhecida tinha morado antes de suicidar-se em busca talvez de "uma carta, um diário, um simples papel onde tivesse cabido o desabafo, o grito" (TN, p. 167) :

(...) O espírito humano, porém, quantas vezes será preciso dizê-lo, é o lugar predilecto das contradições, aliás nem se tem observado ultimamente que elas prosperem ou simplesmente tenham condições de existência viáveis fora dele, e essa deve ser a causa de andar o Sr. José às voltas pela cidade, de lado para lado, para cima e para baixo, como perdido sem mapa nem roteiro, quando sabe perfeitamente o que tem de fazer neste último dia, que amanhã já será outro tempo, ou que será ele o outro num tempo igual a este, e a prova de sabê-lo foi ter pensado, Depois disto, quem serei eu amanhã, que espécie de auxiliar de escrita vai ter a Conservatória Geral do Registo Civil Duas vezes passou em frente da casa da mulher desconhecida, duas vezes não parou, tinha medo, não lhe perguntemos de quê, esta contradição é das que estão mais à vista, o Sr. José quer e não quer, deseja e teme o que deseja, toda sua vida tem sido assim.(...) (TN, p. 268)

Este pensamento do protagonista revela sua transformação, após um longo aprendizado. Porém, ele ainda parece comportar-se como se estivesse se revoltado contra o sistema burocrático, fazendo uso dele para o seu empreendimento pessoal e, ao mesmo tempo, já parece mostrar a sua resignação ao prever o seu retorno ao espaço que por algum tempo abandonou.

O Sr. José vai enfim ver o apartamento em que ela tinha morado quando se divorciou e passa a ter contato com os objetos pessoais dela, o que o leva a ir-se convencendo de que não poderia fazer mais nada, de que a sua busca tinha chegado ao fim. A própria descrição da casa da desconhecida e de tudo que presencia, parece suficiente para que ele, finalmente, desse aquele caso por encerrado. $\mathrm{Na}$ descrição seguinte, podem-se perceber as impressões que o Sr. José vai adquirindo desta visita - 
ao fazer o confronto de tudo que tinha ouvido sobre aquela mulher; e como ele vai tirando as suas conclusões.

Seu impasse acaba por se resolver quando entra na casa onde a desconhecida tinha morado. Pela descrição do narrador verifica-se o quanto o Sr. José se atém aos detalhes na distribuição dos cômodos; o seu estranhamento ao ouvir o telefone tocar e uma voz feminina gravada na secretária eletrônica a anunciar que não estava no momento. Estes detalhes vão, aos poucos, convencendo o Sr. José de que de fato a mulher desconhecida já não existia e de que a sua busca estava chegando ao fim:

(...) E há as gavetas da secretária que não chegou a investigar, e os pequenos armários da estante de livros, em algum sítio terá de estar guardado aquilo que veio procurar, a carta, o diário, a palavra de despedida, o sinal da última lágrima. Para quê, perguntou, suponhamos que tal papel existe, que eu o encontro, que o leio, não será por lê-lo que os vestidos dela deixarão de estar vazios, a partir de agora os exercícios de matemática não terão solução, não se descobrirão as incógnitas das equações, a colcha da cama não será afastada (...) o que acabou, acabou (...) o telefone tocou. Não dera por ele antes, mas ali estava, numa pequena mesa, a um canto, como um objecto que poucas vezes se utiliza. $\mathrm{O}$ mecanismo do gravador de chamadas funcionou, uma voz feminina disse o número do telefone, depois acrescentou, Não estou em casa, deixe o recado depois de ouvir o sinal (...) O Sr. José levantou-se, Tenho de me ir embora, murmurou, mas antes de sair ainda foi dar uma última volta pela casa, entrou no quarto (...) sentou-se um momento na beira da cama, uma e outra vez deslizou devagar a mão pela dobra bordada do lençol (...) ali estavam os vestidos da mulher que havia dito as definitivas palavras, Não estou em casa. Inclinou-se para eles até lhes tocar com a cara, ao cheiro que desprendiam poderia chamar-se cheiro de ausência, ou será antes aquele perfume misto de rosa e crisântemo que na Conservatória Geral de vez em quando perpassa. (...) (TN, p. 273)

A passagem transcrita acima, da visita do Sr. José à moradia da desconhecida antes de suicidar-se, é repleta de nuances e metáforas. Nesta etapa, o Sr. José quer aterse a todos os detalhes, como se fosse possível recuperar a mulher desconhecida por meio dos seus pertences. O seu contato será com os objetos que pertenceram a ela, a sua voz gravada na secretária com a expressão: "Não estou em casa, deixe o recado depois de ouvir o sinal" $(T N)$. Depois do recado, o narrador apropria-se das palavras ditas pela 
desconhecida e lhes atribui um novo sentido: "ali estavam os vestidos da mulher que havia dito as definitivas palavras". (TN).

Apesar de mostrar-se surpreendido e demonstrar interesse em vasculhar aqueles objetos, o Sr. José vai-se convencendo de que sairá dali sem nenhuma revelação. Tanto que ele ainda pensa em dormir na cama da mulher, talvez num desejo de contato, mesmo que virtual com ela, porém da mesma forma que vêm, estes pensamentos também vão e, ele resolve ir embora, achando que o caso havia sido encerrado. $\mathrm{O}$ próximo passo do Sr. José será retornar à sua moradia, acoplada à Conservatória, e se defrontar com o conservador, porém com aquele enfrentamento positivo das duas consciências. Isso se revela inclusive de forma metafórica na iluminação uniforme de ambos os espaços, como se se quisesse expressar a abolição de fronteiras entre os dois lugares: Conservatória-moradia, e entre o chefe e o subalterno: Conservador-Sr. José; que conversam agora sem nenhum distanciamento hierarquizador:

(...) Foi então que uns dedos brutais apertaram o coração do Sr. José. Havia luz dentro de casa. Tinha certeza de que a deixara apagada quando saiu, mas, tendo em conta a confusão que reina há tantos dias na sua cabeça, admitiria que se houvesse esquecido, se não fosse aquela outra luz, a da Conservatória, as cinco janelas iluminadas intensamente. Meteu a chave à porta [...]. $\mathrm{O}$ Chefe encontrava-se sentado à mesa, diante dele havia alguns papéis cuidadosamente alinhados (...) (TN, 276).

Como se vê, a trajetória do Sr. José acarretará mudanças na sua forma de conceber o mundo e provocará transformações em seu ambiente de trabalho, assim como influenciará o seu chefe no seu processo de autoconsciência. Deste modo, o desenvolvimento da consciência do Sr. José influenciará a tomada de decisão do conservador no que se refere à arrumação dos arquivos dos vivos e dos mortos que se constitui na maior inversão carnavalesca de Todos os nomes, como veremos a seguir. 


\subsection{A autoconsciência do conservador}

A figura do conservador vai adquirindo a sua autoconsciência, à medida que vai acompanhando a trajetória do Sr. José. Até certo momento ele age como um Deus que acompanha todos os passos do seu cordeiro sem que este saiba. O conservador pode ser visto na obra estudada como o duplo do Sr. José. Não há como conceber uma personagem sem a outra. Ambas, apesar de serem caracterizadas de forma diferente, principalmente no início do romance, possuem pontos em comum, dos quais só se vai tomando ciência, à proporção que se desenvolve a leitura da narrativa.

O papel desempenhado pelo conservador no início da obra revela a sua atitude de aceitação do status quo. Neste estágio, ele faz o papel de autoridade máxima da Conservatória, agindo como um verdadeiro déspota. Sua caracterização é semelhante à de um ditador, a quem todos os funcionários devem respeito. Ele representa a linhagem de conservadores que pregam a preservação das tradições, dos bons costumes, da impessoalidade nas relações de trabalho. A sua figura é traçada como extremamente severa, exemplo de disciplina, portador de um discurso e de uma memória lendários.

De forma semelhante ao Sr. José, o conservador deve ser entendido como uma personagem inacabada e, portanto, caracterizado como um ideólogo em busca de sua autoconsciência. Daí poder-se afirmar que, assim como o Sr. José, ele também vivencia as categorias típicas do herói dostoievskiano analisado por Bakhtin em sua obra Problemas da poética de Dostoiévski. São elas: “aceitação e rejeição; revolta ou resignação" (BAKHTIN, 2005, p. 77).

Porém, é preciso esclarecer que estas categorias não ocorrem de forma estanque; assim como acontece no desenvolvimento do processo de autoconsciência do Sr. José, 
elas se imbricam uma com as outras, demonstrando ambigüidade. Por exemplo, no episódio em que o Sr. José, após invadir o colégio em que a desconhecida havia estudado e lecionado, é acometido por um forte resfriado, nota-se, na fala do conservador, a sua preocupação com o Sr. José.

Demonstrando mudanças em seu comportamento, o conservador é quem se encarregará de providenciar assistência médica e garantir a alimentação e bem-estar ao funcionário durante os dias em que ele precisa ficar de repouso. O episódio será marcado pelo estranhamento tanto do Sr. José, como dos demais funcionários da Conservatória, que julgam extremamente inadequadas ao seu cargo as atitudes do conservador em mostrar-se preocupado com o estado de saúde de um subalterno, a ponto de enviar um encarregado para saber notícias e avisar das providências com a assistência médica.

$\mathrm{Na}$ transcrição seguinte, observa-se a preocupação do conservador em enviar o mesmo médico que cuida da sua saúde e da sua família:

(...) Boa tarde, senhor doutor, diga antes má tarde, senhor conservador, boa tarde seria eu estar agora no quentinho do consultório (...) Como vai o nosso doente, perguntou o conservador, e o médico respondeu (...) é só uma gripe (...) o Sr. José tremia (...) porém o tremor, irreprimível não era de febre que vinha mas de uma espécie de pânico (...) o chefe aqui pensava, o chefe na minha casa, o chefe que lhe perguntava, Como se sente, Melhor, senhor, Tomou os comprimidos que lhe mandei, Sim senhor, Fizeram-lhe efeito, Sim senhor, Agora deixará de tomar esses e passará a tomar os remédios que o doutor tiver receitado (...) só tem a mais umas injeções, eu trato-lhe disso. O Sr. José mal podia acreditar que a pessoa que, diante dos seus olhos, estava a dobrar a receita e a guardá-la cuidadosamente no bolso fosse realmente o chefe da Conservatória Geral. O chefe que ele a duras penas aprendera a conhecer nunca se comportaria desta maneira, não viria em pessoa interessarse pelo seu estado de saúde, e a hipótese de querer, ele próprio, encarregar-se da compra dos medicamentos de um auxiliar de escrita seria simplesmente absurda. (...) Eu trato de tudo, senhor doutor, disse o conservador, telefono ao enfermeiro da Conservatória, ele compra os remédios e vem cá dar as injeções. Já não se encontram muitos chefes como o senhor, disse o médico. O Sr. José acenou debilmente a cabeça, era o máximo que conseguiria fazer (...) (TN, p. 127-128). 
Atente-se para o modo familiar e carinhoso como o conservador se refere ao Sr. José, na presença do médico, como "nosso doente". Como se não bastasse, ainda faz uso de um tom de voz ao qual o Sr. José não estava acostumado, mostrando-se preocupado em saber se havia recebido os comprimidos que ele havia enviado. Enfim, o Sr. José mostra-se totalmente desajeitado com tantas gentilezas. Como se, de uma hora para outra, o conservador tivesse mudado da água para o vinho.

Chega a ser possível dizer, ainda sobre este episódio, que o conservador assume a responsabilidade de cuidar ele mesmo do tratamento do Sr. José, como uma demonstração de cuidado com alguém que possui uma identificação com outro, de maneira a querer doar-se da melhor maneira possível. Além disso, pode-se observar que o discurso do conservador é o inverso do discurso usado pelo Sr. José quando estava a empreender a sua busca. Enquanto o funcionário utiliza-se da palavra de autoridade, assim como da credencial, com o intuito de obter êxito nas suas visitas, o conservador, por outro lado, faz uso do mesmo tipo de discurso só que para promover o bem-estar do funcionário com quem começa a identificar-se.

Mais adiante o conservador demonstra novamente uma atitude de espelhamento em relação ao Sr. José, o que fica perceptível pela comparação que o narrador faz entre as duas personagens. Num tom irônico ele esclarece que o atendimento médico dispensado ao Sr. José nada tem a ver com a eficácia do sistema de saúde em vigor na Conservatória, mas, relaciona-se à influência do conservador. O narrador também alude à reação do médico, como se este não estivesse a entender o motivo daquele tratamento especial dispensado pelo conservador ao funcionário:

(...) conseqüência, simplesmente, da claríssima ordem do chefe da Conservatória Geral, Senhor doutor, trate-me aquele homem como se estivesse a tratar-me a mim, é importante. O médico não atinava com as razões do óbvio tratamento de favor que lhe estava a ser recomendado e muito menos com a falta de objectividade da opinião valorativa expressa, 
conhecia de alguma visita profissional a casa do conservador, a sua maneira confortável e civilizada de viver, um mundo interior sem qualquer semelhança com o tugúrio tosco deste Sr. José permanentemente mal barbeado e que parecia não ter lençóis para mudar (...) (TN, p.137).

Percebe-se uma somatória de atitudes que demonstram o nascimento de uma mútua empatia entre as duas personagens. O conservador, como representante máximo da hierarquia burocrática, que deve manter a sua aparência para garantir o funcionamento da máquina burocrática, ao acompanhar a trajetória do auxiliar de escrita, começará a identificar-se com ele a ponto de, aos olhos dos demais funcionários, comportar-se de forma inadequada a um chefe da Conservatória Geral. Já o Sr. José, por um determinado período, que sempre procurara manter uma postura condizente com o perfil da Conservatória, começa a transgredir algumas regras da instituição.

$\mathrm{Na}$ passagem em que quebra todas as convenções burocráticas e desloca-se do seu local de trabalho para conversar com o médico sobre o estado de saúde do Sr. José, o conservador parece iniciar o seu processo de rejeição à ordem estabelecida. No entanto, como já foi dito, este processo não ocorre isoladamente, como se, de repente, as personagens negassem as suas atitudes anteriores; ele ocorre de forma contraditória, muitas vezes: ora as personagens aceitam, ora rejeitam, assim como ora se revoltam, ora se resignam ao papel que exercem no seu meio.

À medida que o protagonista ousa empreender a sua busca, o conservador age como um observador à distância, sem que o protagonista perceba, de tão absorto que se encontrava na sua procura. O momento de maior aproximação entre ambos ocorre exatamente no episódio que se acabou de transcrever, quando o chefe lhe envia um médico e depois um enfermeiro para aplicar-lhe as injeções e levar-lhe comida; assim como no final do romance quando se encontra sentado na mesa do Sr. José. Na conversa do enfermeiro com o Sr. José, pode-se ler a revelação da cumplicidade do chefe na investigação feita pelo protagonista: 
(...) É ou não é verdade que os conservadores têm pouco trabalho, É verdade, toda a gente fala disso, Pois fique então a saber que a ocupação principal deles, nas muitas horas vagas que gozam, enquanto o pessoal está a trabalhar, é coligir informações sobre os subordinados, toda a espécie de informações, fazem-no desde que a Conservatória Geral existe (...) o estremecimento do Sr. José não passou despercebido ao enfermeiro (...) Pretende insinuar que o chefe lhe costuma fazer confidências, Nem ele mas faz, nem eu estou a insinuar que as faça, simplesmente recebo ordens, Então só tem de cumprilas, Engana-se, tenho de fazer muito mais do que cumpri-las, tenho de interpretá-las, Porquê, Porque entre o que ele manda e o que ele quer há geralmente diferença, Se o mandou vir cá foi para me dar uma injecção, Essa é a aparência, Que foi que viu neste caso, além da aparência que têm, Você não é capaz de imaginar a quantidade de coisas que se descobrem olhando para umas feridas (...) (TN, p. 133).

Neste diálogo entre o enfermeiro e o Sr. José, percebe-se a atitude contraditória do conservador, que, ao mesmo tempo que demonstra preocupação com a saúde do Sr. José, também deseja obter informações sobre as suas andanças. Para ter um controle maior sobre o funcionário ou por identificar-se com a atitude dele ou pelas duas possibilidades.

Outro episódio que contribui para elucidar as mudanças na forma de pensar do conservador, de acordo com as categorias de autoconsciência, relaciona-se ao momento em que ele discursa para os funcionários, fazendo uso legítimo do seu cargo. Neste discurso o conservador irá citar alguns acontecimentos de que tomou conhecimento e que terminaram influenciando-o a tomar medidas que promovessem mudanças na maneira de organizar os arquivos, sem separar os vivos dos mortos.

Outro exemplo relacionado à atitude de revolta do chefe acontece quando os funcionários começam a pensar que o conservador irá repreender mais uma vez o senhor José, pois justamente nesse dia ele chega atrasado ao serviço. Porém todos são surpreendidos pela fala do conservador, que, após uma longa explanação sobre a sua prática durante anos de trabalho, de zelar pela disciplina e o bom funcionamento do serviço, também falará sobre as condições precárias da Conservatória sem “uma só 
máquina de escrever, para não falar nos instrumentos mais modernos" e da tradição de anos que ele procura sustentar.

Mais adiante, o conservador falará da necessidade de promover mudanças urgentes na arrumação dos arquivos, o que faz pensar que, ao acompanhar cada passo do Sr. José, ele vai adquirindo uma nova consciência, que o fará rever suas posturas, tal como demonstra a sua atitude em ordenar a abolição de fronteiras entre os arquivos dos vivos e dos mortos. Este comportamento revela mudanças tanto na arrumação dos arquivos, transformando os procedimentos no local de trabalho, como também na sua forma de conceber o mundo:

(...) a força irresistível da evidência obrigou-me a enfrentar o peso da tradição, de uma tradição que, durante toda a minha vida, eu havia considerado inamovível. Chegar a esta consciência dos factos não foi obra do acaso nem súbita revelação. Por duas vezes desde que sou chefe da Conservatória recebi aqui avisos premonitórios, (...) mas que, hoje o compreendo, preparam o caminho para que viesse a acolher com o espírito aberto um terceiro e recente aviso, do qual, por razões que entendo dever conservar secretas, não falarei nesta ocasião. (...) e eu direi, com toda a humildade, que se não houvessem ocorrido recentemente certos outros factos e se eles não tivessem suscitado em mim certas outras reflexões, nunca eu teria chegado a compreender a dupla absurdidade que é separar os mortos dos vivos. (...) reunamos em um só arquivo, a que passaremos a chamar simplesmente histórico, os mortos e os vivos, tornando-os inseparáveis neste lugar, já que lá fora a lei, o costume e o medo não o consentem. Farei baixar portanto uma ordem de serviço em que se especificará, primeiro, que a partir desta data os mortos permanecerão no mesmo lugar do arquivo que tinham ocupado em vida, segundo, que progressivamente, processo a processo, documento a documento, dos mais recentes aos mais antigos, se procederá à reintegração dos mortos do passado no arquivo que passará a ser o presente de todos (TN, p. 205-209)

Ao final do discurso, o conservador demonstra que, mesmo propondo estas mudanças, ele continua a exercer o papel de chefe e, portanto, não mudará a forma de pensar em relação aos procedimentos disciplinares da Conservatória. No trecho a seguir, observa-se, na postura do conservador, uma atitude de resignação: 
(...) O conservador voltara a ser o chefe que conheciam desde sempre, sobranceiro e irônico, implacável nos juízos, rigoroso na disciplina, como logo a continuação deixou a claro. Apenas no vosso interesse, não no meu, ainda tenho para vos dizer que o pior dos erros da vossa vida seria considerar como um sinal de fraqueza pessoal ou de diminuição de autoridade oficial o facto de vos ter falado de coração e mente abertos. Se não me limitei a ordenar simplesmente, sem explicações, como seria meu direito, a reintegração ou unificação dos arquivos, foi só porque vos quis fazer compreender as razões profundas da decisão que tomei, foi só por desejar que o trabalho que vos espera seja executado com o espírito de quem se sente a edificar algo e não com o alheamento burocrático de quem foi mandado juntar papéis a papéis. A disciplina nesta Conservatória Geral continuará a ser a que sempre foi, nenhuma distracção, nenhum devaneio, nenhuma palavra que não esteja diretamente relacionada com o serviço, nenhuma entrada fora de horas, nenhuma mostra de desleixo no comportamento pessoal, tanto nos modos como na aparência .(...) (TN, p.210)

No final da narrativa o conservador aguarda a chegada do Sr. José. No momento em que ambos se confrontam, o conservador irá confessar a sua cumplicidade nos "atos irregulares" do auxiliar. Nesta postura identifica-se uma atitude de revolta do conservador ao assumir sua parcela de participação nas contravenções praticadas pelo protagonista e ao propor ao Sr. José a prática de uma irregularidade tal como a de omitir a data do falecimento da desconhecida. Paralelamente identifica-se uma atitude de resignação ao manter-se na sua postura de chefe. É bom lembrar mais uma vez que será o conservador, no seu papel de autoridade máxima da Conservatória, quem irá tomar a decisão de abolir as fronteiras entre os arquivos dos vivos e dos mortos, tentando adequar a realidade da Conservatória às descobertas do Sr. José:

(...) tenho seguido regularmente as suas actividades, além disso o seu caderno de apontamentos foi-me de grande ajuda (...) estou prestes a tornar-me em cúmplice das suas irregulares acções (...) Sabe qual é a única conclusão lógica de tudo o que sucedeu até este momento (...) fazer para esta mulher um verbete novo, igual ao antigo com todos os dados certos, mas sem a data do falecimento (...) depois colocá-lo no ficheiro dos vivos, como se ela não tivesse morrido (...) seria uma fraude, mas nada do que temos feito e dito, o senhor e eu, teria sentido se não a cometêssemos (...) lembra-se de eu me ter referido a certos factos sem os quais nunca teria chegado a compreender a absurdidade que é separar os mortos dos vivos (...) Precisarei de dizer-lhe a que factos me referia (...) (TN, p. 277-278) 
Pode-se concluir que tanto o Sr. José quanto o conservador agem como protagonistas nas mudanças empreendidas na Conservatória. Neste sentido, caberá ao primeiro a iniciativa de fazer uma grande viagem pelos labirintos da Conservatória, da Cidade, da Escola e do Cemitério, até retornar transformado para a Conservatória, sendo que esta não será mais a mesma nem ele também. Já o conservador age como um Deus que passará de chefe, que a todos os funcionários vigia como forma de garantir o cumprimento do trabalho e das normas disciplinares, para a de observador e cúmplice dos atos irregulares do Sr. José, o que acarretará a sua mudança de concepção da realidade, ao promover uma nova arrumação dos arquivos, como já foi exemplificado anteriormente. 


\title{
4. O desmascaramento do poder burocrático.
}

\begin{abstract}
"Em várias artes, e por excelência nessa de escrever, o melhor caminho entre dois pontos, ainda que próximos, não foi, e, não será, e não é a linha a que chamam reta, nunca por nunca ser, modo este energético e enfático de responder a dúvidas, colocando-as."
\end{abstract}

José Saramago.

Neste trabalho procura-se defender a idéia de que a obra Todos os nomes, de José Saramago, se vale de uma forma polifônica para refletir sobre as relações de poder, figurativizadas por certas dualidades espaciais, como a Conservatória, o Cemitério, a Escola, de um lado, e o protagonista Sr. José, em seu “périplo" existencial. A polifonia pode ser reconhecida pelo modo como se constroem os diálogos no decorrer da narrativa e pelo modo como todas as vozes - a do autor, do narrador e das personagens ideólogas ${ }^{7}$ - atuam, sem se sobreporem umas às outras. Até mesmo a ideologia do autor participa da trama narrativa; no entanto, ela não se impõe como voz hegemônica.

Para construir essa estrutura polifônica, Saramago faz uso de recursos como a ironia, a carnavalização e as relações intra e intertextuais, procurando, desta forma, instaurar relações dialógicas com outras visões de mundo. Tais recursos servem para dar forma a uma visão ambígua da realidade, concebida tanto como o espaço da troca dialógica entre os indivíduos, quanto como o fruto dessa mesma troca.

É justamente essa óptica o fundamento da ambigüidade desta obra de Saramago, ambigüidade que está presente tanto na linguagem como na própria intenção do autor de

\footnotetext{
${ }^{7}$ Este termo foi usado por Bakhtin em sua obra Problemas da poética de Dostoievski, para nomear as personagens dostoievskianas, às quais, segundo ele, adotam uma postura de preocupação com a realidade em que vivem. Para elas o que importa é o seu pensamento ideológico sobre o mundo.p.77
} 
problematizar a questão do poder burocrático. Esta problematização transparece a partir da atitude do protagonista de sair do isolamento em que se encontrava no início do romance e partir em busca de contato com outros indivíduos, isto é, com outras vozes ideólogas que habitam a obra. Interagir com essas vozes será fundamental para a aquisição da sua autoconsciência, assim como a do conservador.

Já foi mencionado que o Sr. José é inicialmente retratado como submisso ao poder instituído e a evolução da narrativa vai focalizar as mudanças gradativas que se operam nele e que o afastam das relações impessoais que mantinha com o espaço de trabalho na Conservatória. Na esteira do romance polifônico de Dostoiévski, Saramago elege como herói um indivíduo sem características pessoais definidas, mas percorrendo, ao longo da narrativa, um caminho em busca exatamente da sua personalização. O Sr. José configura-se, portanto, como um herói inacabado, e as aventuras que vive destinam-se a contribuir para a inconclusibilidade do seu perfil. Este, a despeito do esforço, vai continuar inconcluso, embora as aventuras sirvam para revelar novos traços à sua autoconsciência (e ao leitor). Em seu ensaio sobre Polifonia, Paulo Bezerra, abordando a relação entre autor e personagem no romance polifônico e explicando a autonomia da personagem em relação ao autor, diz que a personagem "não é uma coisa, um objeto silencioso; é outro sujeito, outro 'eu' investido e iguais direitos no diálogo interativo com os demais falantes, outro eu a quem cabe auto-revelar-se livremente." (in BRAIT, 2007, 193.)

As posturas tanto do Sr. José quanto do conservador devem ser analisadas sob a óptica da carnavalização, que se constitui numa forma de se conceber a realidade de forma múltipla, em que não existe a predominância de nenhuma verdade. Aliás, a única certeza, se é que se pode usar este termo na atualidade; é a ausência de um parâmetro absoluto. Portanto, devemos ter o cuidado de interpretar a obra estudada, como uma 
visão caleidoscópica da realidade em que não há espaço para nenhum tipo de exclusivismo. A própria organização da obra Todos os nomes expressa este pensamento, ao abordar o tema do poder burocrático. É possível interpretar a própria escolha do tema (a crítica à sociedade burocrática) e dos cronotopos da obra como um meio de o autor promover o questionamento da própria organização social contemporânea e até mesmo o sistema de pensamento excludente e compartimentado que rege esta organização, que seria o pensamento cartesiano.

Porém, juntamente com esta visão sobre o pensamento, está latente a presença do seu contrário, como sugerem a arquitetura e as formas de organização espacial da Conservatória e do Cemitério. Entre ambos os espaços parece haver uma relação de prolongamento (ambos acolhem em seu interior a vida e a morte), de espelhamento (têm muitas semelhanças na fachada, por exemplo), porém há algumas diferenças que podem ser bastante significativas: no Cemitério não há as divisões e compartimentações rígidas da Conservatória; não há muros separando "os vivos" (da cidade) e os mortos (do cemitério); a luz que ilumina a Conservatória é a luz artificial (às vezes é até uma pequena lanterna de bolso) enquanto é a luz do sol ou da lua (natural, portanto) que ilumina o Cemitério quando o protagonista vai visitar o túmulo da mulher desconhecida).

A questão da luminosidade também merece destaque, pois remete à identificação da Conservatória com uma caverna, numa possível intertextualidade com a alegoria platônica. A sugestão implícita nessa analogia evidentemente é a de que as coisas deste mundo não passam de aparência, de "simulacros". A luz natural, por sua vez, parece remeter à iluminação da consciência, obtida por meio (possivelmente) do desfazimento das fronteiras que limitam as esferas epistemológicas e ontológicas acerca da existência, traduzidas, neste contexto, pelas tópicas da vida e da morte. 
Considerando-se esta leitura interpretativa, chama a atenção o fato de que, em Todos os nomes, a contrapartida dessa realidade de simulacros não está na transcendência, no espaço do absoluto, como propunha Platão. Está, sim, como se vê pelo percurso do Sr. José e pela evolução do seu nível de autoconsciência, no próprio espaço da realidade terrena, porém a ela acrescentando-se o peso axiológico das atitudes conferido pelo protagonista aos seus atos ao longo da narrativa, como já foi demonstrado no capítulo anterior. Em outras palavras, a passagem de um espaço (negativo) ao outro (positivo, iluminado pela autoconsciência) se dá por meio da linguagem, do diálogo, da relação. Trata-se de um trânsito da impessoalidade para a interação.

O Sr. José convive com as esferas do oficial quanto com as do oficioso. A sua vida se desenrola entre a preocupação em manter-se com a aparência de funcionário exemplar, cumpridor de suas obrigações, submisso ao seu chefe, ao mesmo tempo que procura assumir o seu papel de sujeito de sua própria história, ao persistir no seu trabalho de investigador da vida da mulher desconhecida.

Esta postura do protagonista faz relembrar o procedimento carnavalesco, tal como concebido por Bakhtin em sua obra $A$ cultura popular na Idade média e no Renascimento, na qual ele defende que: "a cosmovisão carnavalesca é dotada de uma poderosa força vivificante e transformadora e de uma vitalidade indestrutível" (BAKHTIN, 2008, p.107).

Nesta obra, Bakhtin faz uma análise das diversas manifestações da cultura carnavalesca durante o período da Idade Média e do Renascimento, e de que forma ela influenciou a literatura de Rabelais. Segundo Bakhtin, faz parte da linguagem carnavalesca a defesa do princípio da relatividade de tudo que se autodenomina como verdade, assim como de toda espécie de poder. Entre outras características da cultura 
carnavalesca está à visão de mundo às avessas e a abolição temporária de barreiras hierárquicas entre os indivíduos. Esta idéia pode ser vista na citação seguinte:

Todas as formas e símbolos da linguagem familiar estão impregnados do lirismo da alternância e da renovação, da consciência da alegre relatividade das verdades e autoridades no poder. Ela caracteriza-se, principalmente, pela lógica original das coisas ao avesso, ao contrário, das permutações constantes do alto e do baixo, da face e do traseiro, e pelas diversas formas de paródias, travestis, degradações, profanações, coroamentos e destronamentos bufões. A segunda vida, o segundo mundo da cultura popular constrói-se de certa forma como paródia da vida ordinária, como um mundo ao revés (p. 10).

Dentre as características carnavalescas citadas, observa-se a presença da inversão, da relatividade e da renovação na obra Todos os nomes, de José Saramago, em que, ao mesmo tempo que existe a hegemonia do poder hierárquico, existe também a problematização deste mesmo poder. Ao mesmo tempo que o Sr. José e o conservador se mantêm em seus papéis oficiais de funcionário subalterno e de chefe, eles agem na contravenção. O primeiro, ao assumir o papel de agente desestruturador da instituição burocrática, envolvendo-se em situações das mais embaraçosas sob o pretexto de desvendar os mistérios da mulher desconhecida, procurando reconstituir a sua vida através de investigações que vão muito além dos muros da Conservatória. Já o conservador acompanha a busca do Sr. José com a ajuda dos seus subalternos e do médico e do enfermeiro que cuidam do funcionário no período em que ele adoece. E, quase que de maneira simultânea, à medida que o Sr. José conquista sua autoconsciência, o conservador vai conquistando a dele.

Vai ficando claro para o leitor que, num determinado estágio do seu aprendizado, o Sr. José passa a superar o medo e os receios e começa a encarar a Conservatória e o conservador sob outro viés. Ou seja, será a partir do enfrentamento cada dia mais lúcido das leis rígidas do poder que o protagonista vai conquistando a sua autoconsciência. A deflagração do percurso de busca se dá a partir da sutil sensação de 
insatisfação do protagonista com a falta de sentido do seu estilo de vida. Esta será uma das motivações que o farão arriscar a sua reputação e iniciar um processo de desobediência, que somente terá fim quando ele chegar à conclusão de que o sentido para a sua vida estava dentro dele e que a motivação para esta busca somente aparece quando se começa a encarar a existência como um processo, no qual o que mais importa não é o encontro rápido com o objeto do desejo, mas o aprendizado obtido a partir daí.

A obra Todos os nomes abarca a complexidade do ser humano e a sua necessidade de buscar algum sentido para a sua existência, caso contrário a vida tornase insuportável a ponto de se querer sair dela, assim como se entrou, ou melhor, parafraseando a fala do diretor da escola sobre o suicídio da mulher desconhecida: "Tudo se passou como se ela não tivesse feito mais do que abrir uma porta e sair”.(p.267).

\section{1- O narrador irônico}

Um dos recursos de que faz uso o narrador saramaguiano para promover o questionamento do poder burocrático é o da ironia. Este recurso estilístico, muito recorrente em Todos os nomes, é não só fundamental na desestabilização do discurso oficial da Conservatória, assim como é também um meio de proporcionar uma visão questionadora daquela veiculada pelo discurso oficial.

Em Ironia em perspectiva polifônica, Beth Brait analisa o narrador irônico na obra História do cerco de Lisboa, de José Saramago, apontando a "postura irônica do narrador $[\ldots]$ no sentido de ambigüizar o relato oficial e abrir possibilidades $[\ldots]$ para novas leituras em torno do mesmo episódio" (BRAIT, 1996, p. 62). Na explicação da 
autora, esse tipo de ironia (intitulada ironia verbal) envolve três actantes: um narrador, que produz um relato de uma forma tal que o enunciado seja compreendido como irônico; um leitor (visto pelo narrador como um cúmplice seu) e um alvo da ironia, que estaria na situação narrada. (p.62)

Em seu estudo, Beth Brait defende que o "discurso irônico joga essencialmente com a ambigüidade, convidando o receptor a, no mínimo, [fazer] uma dupla descodificação, isto é, lingüística e discursiva. Esse convite à participação ativa coloca o receptor na condição de co-produtor da significação, o que implica necessariamente sua instauração como interlocutor" (p. 96).

Assim, a narrativa de Todos os nomes, de José Saramago exige dos seus leitores uma atitude como co-autores da história. E é justamente, pelo uso da ironia que este leque de interpretações é desenhado, para que seja possível que o leitor intervenha como interlocutor, inclusive fazendo perguntas ao texto. Pois, como já foi dito anteriormente, o estilo saramaguiano muitas vezes interessa-se em lançar perguntas ao leitor e não fornecer respostas, levando em conta a ambigüidade do seu estilo. A título de exemplo, segue um trecho em que o Sr. José vai à escola onde a mulher desconhecida havia sido professora. Não conhecendo bem o caminho a seguir, o Sr. José decide perguntar a um policial:

(...) Como partia do jardim teve dúvidas sobre a direcção a seguir, pensou que se tivesse comprado o mapa da cidade, como fora sua intenção, não precisaria de estar agora a pedir a um agente policial que o orientasse, mas a verdade é que a situação, a lei aconselhando o crime, lhe deu um certo prazer subversivo. (TN, p. 263)

Para começar, é evidente a importância da adesão do leitor para que se compreenda o sentido que está sendo atribuído, no texto, à palavra crime: irônico porque, na verdade, o Sr. José se estiver de fato cometendo um crime, este poderá ser 
considerado como tal se for adotada a perspectiva centrípeta e autoritária das relações; ou seja, em termos discursivos, esta noção de crime tem como referencial o poder que subjuga e que reprime a liberdade. No contexto do fragmento citado, está visível que a consciência do Sr. José já despertou para o poder cerceador desse poder e já sente prazer na transgressão (e não mais a culpa do início).

Além disso, é relevante destacar que a ironia não existe apenas no enunciado, mas também na enunciação, isto é, no pacto entre narrador e leitor (os dois actantes) em relação a um status quo que precisa ser denunciado, mas pelas vias sutis e indiretas do jogo irônico.

Um outro exemplo de ironia pode ser visto na ambigüidade comportamental do Sr. José, que, num primeiro momento da narrativa, também se espelha no seu chefe e reproduz passiva e pacificamente o poder instituído, porém a sua insatisfação revela-se de forma latente no momento em que resolve entrar na Conservatória pela porta de comunicação com a sua moradia e de forma mais contundente no momento em que se depara com o verbete da desconhecida. Principalmente a partir deste momento passará a fazer uso dessa autoridade para obter as informações sobre a anônima.

Ainda fazendo referência a obra Ironia em perspectiva polifônica, é pertinente para a análise deste romance a afirmação da autora de que o "discurso literário" faz uso da ironia para fazer oposição a "valores que se colocam como únicos verdadeiros, desmascarando-os [...]. Qualquer que seja a dimensão da ironia-frasal ou textual desencadeia-se um jogo entre o que o enunciado diz e o que o enunciado faz dizer, com objetivos de desmascarar ou subverter valores, processo que conta com formas de envolvimento do leitor, ouvinte ou espectador" (BRAIT, 1996, p. 106).

Na obra Todos os nomes o recurso irônico constitui-se num instrumento eficaz na problematização da realidade, o que permite justificar a freqüência com que o autor 
saramaguiano utiliza-o em suas obras. Ao veicular os dois discursos - o da interferência crítica e o anterior, o discurso irônico mostra-se, por sua vez, ambíguo.

Beth Brait defende o princípio de que, para haver ironia, faz-se necessário que o “enunciador chame a atenção não só para o que está sendo dito como para a maneira como está sendo dito e também para as 'contradições existentes entre as duas dimensões"” (Ibid., p. 106).

Uma das idéias predominantes neste estudo sobre ironia é a defesa do pressuposto de que o recurso irônico pode questionar os valores vigentes em nossa sociedade, assim como subverter qualquer idéia de autoridade.

Ao que parece, o dialogismo vai se instaurando em Todos os nomes através do narrador irônico, que proporciona várias possibilidades de interpretação para a obra e não apenas uma. Esta forma de conceber o recurso irônico, como agente propiciador de várias interpretações de uma determinada obra, encontra respaldo no estudo realizado por Beth Brait:

(...) A multiplicação das possibilidades de interpretação desse processo, de captação de um efeito irônico, advém de um conjunto de aspectos dimensionados discursivamente e que incluem a manipulação, a sedução, visando a cumplicidade para um ponto de vista, para uma determinada postura (...) (Ibid., p. 198).

Logo, a ironia é um recurso retórico extremamente rico, que não permite a imposição de uma única visão, mas, ao contrário, joga com esta visão da realidade, de modo a problematizá-la. Além disso, ela exige dos leitores uma participação no processo de construção de sentido ao fazer uso da ambigüidade.

Para a autora, o discurso irônico, ao exigir a participação do leitor e/ou espectador, adquire condições tanto para "reverter não apenas figuras de autoridade, mas relativizar valores estabelecidos, produzindo um efeito humorado graças à 
apreensão simultânea dos dois planos de enunciação, promotores de investimentos contraditórios" (p. 108).

Um outro aspecto retratado por Beth Brait prende-se à forma típica de “interpretação presente na ironia, que se dá a partir da constituição de vozes. Pela maneira de organizá-las, o enunciador evidencia as que lhes são contrárias e as que a ele se alinham, distanciam-se das primeiras, valorizando as outras e constituindo ao mesmo tempo, o parceiro, a recepção qualificada que participará dos sentidos ali instaurados. $\mathrm{O}$ que faz é mostrar o ponto de vista, a maneira de ser dos discursos mobilizados. Ao colocá-los em evidencia, estabelece sua principal estratégia persuasiva. [...] Assim a escritura vai se constituindo como uma espécie de "bricolage", pois, mesmo sendo definida por um projeto, vai se fazendo em forma de apropriação e incorporação de elementos preexistentes que resultam num conjunto inteiramente novo. Ao construir-se dessa maneira, constitui seu próprio modelo e os modelos de sua recepção. Naturalmente, o resultado pode propiciar, como nos discursos em geral, um novo paradigma" (p. 197).

No primeiro capítulo de Todos os nomes já está perceptível a forma irônica com que o narrador se refere à divisão de tarefas dentro da Conservatória, alegando que esta distribuição obedece a uma regra simples: "a de que os elementos de cada categoria têm o dever de executar todo o trabalho que lhes seja possível, de modo a que só uma mínima parte dele tenha de passar à categoria seguinte.” (p. 12). Neste trecho, percebemos o posicionamento irônico e, ao mesmo tempo, crítico de Saramago em relação ao serviço burocrático, cujas divisões de tarefas são muitas vezes injustas, de maneira que aos funcionários que ocupam o cargo de auxiliares de escrita, como o Sr. José, é reservada a maior parte do trabalho, enquanto os que ocupam um lugar superior da escala hierárquica trabalham menos. 
Nota-se que esta forma de narrar expressa uma visão problematizadora do poder burocrático, sem cair no discurso engajado. Assim, o uso do recurso irônico por Saramago é uma forma encontrada pelo autor para denunciar o tratamento injusto a que os funcionários da Conservatória estão submetidos, sem fazer uso de um discurso engajado e assertivo, que representaria uma visão monológica da realidade, que, por sua vez, soaria como contraditória em relação à proposta do autor.

Ainda no primeiro capítulo de Todos os nomes, há ironia quando o narrador demonstra a preocupação do conservador com a aparência, ao ordenar ao Sr. José que mudasse uma das capas dos arquivos, pois estava com aspecto amarelado, com "manchas escuras", que provocam uma péssima impressão, "ofendendo a vista do público" (TN, p.16). Mais uma vez o procedimento irônico serve para denunciar a atenção demasiada com o aspecto da aparência que envolve o poder burocrático, como se tudo funcionasse em torno disso. Estas passagens vão, inclusive, contribuindo para chamar a atenção para a crítica eminente ao poder instituído, além de servir para desmascarar esse mesmo poder.

Mais adiante se observa a intervenção irônica do narrador num momento em que o Sr. José e o conservador estão experimentando situações mais humanizadas e terminam provocando certa dose de indignação nos demais funcionários da Conservatória. Esta idéia está presente no trecho em que o Sr. José, tendo pegado um forte resfriado, avisou aos colegas que não ia trabalhar. E ainda no momento em que o conservador manda avisá-lo de que estimava sua melhora. Além disso, o narrador faz referência à posição da cabeça baixa do chefe no instante em que o Sr. José tenta agradecer-lhe com o olhar. Ao fazer referência à posição da cabeça do conservador, como se estivesse concentrado no seu trabalho, o narrador interfere de forma irônica, procurando advertir a um eventual leitor desavisado que visse nessa postura uma atitude 
preocupada com o trabalho, sugerindo que tal prática não era usual na Conservatória, pois o conservador, em função do seu cargo, praticamente não tinha o que fazer:

(...) Estupefacto, o Sr. José ainda teve presença de espírito suficiente para olhar na direcção do conservador a fim de lhe agradecer o inesperado voto, mas ele tinha a cabeça baixa como se estivesse aplicado ao trabalho, o que conhecendo nós os costumes laborais desta Conservatória Geral, é mais do que duvidoso (...) (TN, p. 116-117; grifos meus).

A ironia deste trecho pode ser vista no inusitado da situação: o Sr. José irá romper as normas burocráticas e se apresentará na Conservatória em trajes de dormir para avisar ao seu superior que não poderia ir trabalhar. Ao mesmo tempo, o conservador, também age de maneira inapropriada ao fixar o olhar para o Sr. José e baixar a cabeça, na seqüência. O narrador ironiza esta atitude no momento em que põe em dúvida a concentração do conservador na realização do seu trabalho.

$\mathrm{Na}$ citação feita anteriormente, observa-se que, por trás de suas intervenções irônicas, o narrador quer passar a idéia de conflito entre espaços de representação e espaços em que se procura construir relações autênticas pela via da linguagem da persuasão, ou seja, da linguagem dirigida para o interlocutor. Talvez este dilema que, ao que parece, está presente em toda a narrativa de Todos os nomes, não tenha sido solucionado, o que, aliás, não nos causa estranhamento, especialmente levando-se em conta que a obra ficcional não tem a função de responder a todas as perguntas, mas, ao contrário, talvez de fazê-las.

Ainda quanto à intervenção irônica do narrador em relação ao trabalho realizado pelo conservador, pode-se citar o trecho subseqüente ao episódio em que o Sr. José apresenta-se na Conservatória alegando estar doente e incapacitado de trabalhar, no qual o enfermeiro, encarregado de medicá-lo, irá fazer a confissão do trabalho de espionagem do conservador durante o seu tempo livre: 
(...) É ou não é verdade que os conservadores têm pouco trabalho, É verdade, toda a gente fala disso, Pois fique então a saber que a ocupação principal deles, nas muitas horas vagas de que gozam, enquanto o pessoal está a trabalhar, é coligir informações sobre os subordinados (...) (TN, p. 133).

Chega, inclusive, a provocar o riso do leitor a constatação (irônica) do narrador acerca da semelhança entre o tipo de atividade do conservador e o do Sr. José: ambos colecionam dados "inúteis" sobre a vida alheia; diferem as motivações e as circunstâncias que envolvem as atividades de cada um dos dois sujeitos: a coleção do conservador está voltada para a intenção de vigiar os subordinados; a do Sr. José tem o fim de minimizar o tédio e o vazio da existência (o que, examinando-se bem, torna inútil e ridícula a vigilância do conservador...)

Como já foi dito, o recurso irônico é muito utilizado em Todos os nomes como forma de ambigüizar a visão que se tem do poder instituído e refletir até que ponto a realidade aparente corresponde à realidade. Outra passagem em que se pode detectar a presença deste procedimento é aquela em que o Sr. José falsifica a credencial, na qual se pode vislumbrar a denúncia a atos irregulares fáceis de serem cometidos numa instituição como a Conservatória Geral em que, deduz-se, os funcionários ficaram de tal maneira impregnados pelas normas vigentes que seriam incapazes de desobedecer a alguma delas. A atitude do conservador de manter a chave de comunicação da Conservatória, com o Sr. José, pode ser vista como uma forma de atestar esta confiança ou até mesmo de medi-la, o que, por fim, terminará ocasionando o estopim de freqüentes práticas irregulares.

As imagens das principais personagens em Todos os nomes - o Sr. José e o conservador - vão se desprendendo da oficialidade para assumir uma postura oficiosa. Ambas as personagens perfazem trajetórias paralelas à rotina da Conservatória, agem de forma misteriosa. Porém, ambas terminam se denunciando no transcorrer da narrativa, 
ao adotarem posturas inadequadas ao convívio burocrático. O recurso irônico se encarrega de promover o sentido ambíguo da narrativa, além disso, ele nos convida a agir como interlocutores do narrador e intérpretes dos sentidos subliminares do texto.

Em toda a narrativa de Todos os nomes, de José Saramago, reconhece-se a intervenção irônica do narrador. A todo o momento, esse narrador questiona as relações sociais calcadas no embate entre as instâncias de poder e entre as diversas verdades que cada uma dessas instâncias instaura. Outro exemplo está no trecho em que o narrador faz menção à atitude inadequada do Sr. José em comentar com a funcionária da lavanderia sobre o seu local de trabalho, pois isso poderia comprometer a imagem da Conservatória (o narrador levanta a hipótese de a moça ter o mesmo comportamento investigativo do Sr. José e mostrar-se curiosa com o fato de um auxiliar de uma instituição de tanto respeito levar suas vestes naquelas condições para serem lavadas e costuradas). Mais uma vez, o narrador ressalta o episódio da invasão da escola, ou seja, por mais que o protagonista tentasse apagar as marcas do delito cometido, novamente ele depara-se com situações que o fazem relembrar o episódio da invasão da escola, como se fosse uma passagem importante no seu processo de emancipação:

(...) Sou funcionário da Conservatória Geral do Registo Civil, Ah, o senhor é funcionário da Conservatória, disse a empregada da lavanderia com uma modulação nova de respeito na voz que o Sr. José achou melhor deixar passar por alto, arrependido de se ter descaído a dizer pela primeira vez onde trabalhava, um profissional de assaltos nocturnos a sério não andaria por aí a semear pistas, imaginemos que esta empregada de lavanderia é casada com o empregado da loja de ferragens onde o Sr. José foi comprar o corta-vidros ou do talho onde comprou a banha, e que logo à noite, numa dessas conversas banais com que os maridos e as mulheres entretêm o serão, vêm à baila estes pequenos episódios do quotidiano comercial, por muito menos têm ido outros criminosos para a cadeia quando julgavam estar a salvo de qualquer suspeita (TN, p. 145-146; grifos meus).

A interferência irônica do narrador pode ser identificada quando ele se preocupa com as suspeitas que o funcionário da Conservatória poderia levantar na moça da lavanderia e quanto ficaria mal se ele fosse descoberto, pois cairia por terra a aparência 
de seriedade do serviço burocrático (que, aos olhos do Sr. José enquanto "bom funcionário", necessita ser preservada).

O que se constata neste trecho, assim como nos demais, é a preocupação do narrador em mostrar o quanto as relações sociais estão pautadas numa visão unilateral da realidade, que só consegue enxergar as coisas sob a óptica do poder dominante, em que os vários aspectos da vida social são vistos de forma excludente, tais como o poder oficial e o poder oficioso; aparência e essência; chefe e empregado; vida e morte; dominante e dominado, entre outros.

No trecho do romance em que o Sr. José resolve visitar a última residência da mulher desconhecida, antes de casar-se, o narrador comenta de forma irônica o desastre que seria, caso o protagonista se deparasse com um dos moradores do prédio, que para a sua surpresa era um dos subchefes, como ele ficará sabendo posteriormente. Novamente, neste episódio, nota-se que o aspecto ironizado tem relação com a possibilidade de o Sr. José ser desmascarado na sua busca, por "um dos subchefes da Conservatória":

\begin{abstract}
(...) Não sabia ele que um dos moradores do prédio era precisamente, por diabólica casualidade, um dos subchefes da Conservatória, pode adivinhar-se com facilidade a cena terrível, o nosso confiado Sr. José a bater à porta, a mostrar o verbete, talvez mesmo a falsa credencial, e a mulher que o viera atender a dizer-lhe perfidamente, Volte cá mais tarde, quando o meu marido estiver em casa, esses assuntos são com ele, e o $\mathrm{Sr}$. José tornaria, com o coração cheio de esperanças, e daria de cara com um irado subchefe que lhe daria imediata voz de prisão, em sentido próprio se diz, não no figurado, os regulamentos da Conservatória Geral do Registo Civil não admitem leviandades nem improvisações (...) (TN, p. 151-152; grifos meus).
\end{abstract}

Novamente, o narrador interfere para denunciar as atitudes irregulares em relação ao poder instituído da Conservatória, da qual as duas personagens - tanto o Sr. José quanto o conservador, são as maiores representantes. 
Na sua conversa com o farmacêutico, o Sr. José terminará se retraindo pelo olhar de censura do homem e resolve não mostrar a credencial falsa por medo de ser denunciado. Esta atitude cautelosa justifica-se pelo fato de a farmácia ficar próxima ao prédio onde morava o subchefe, o que constituía um risco para o Sr. José de que o farmacêutico o denunciasse. Pelo modo como o farmacêutico é descrito percebe-se o olhar irônico do narrador:

(...) Que deseja, perguntou, Ando à procura duma pessoa, respondeu o Sr. José, ao mesmo tempo que levava a mão ao bolso interior do casaco para exibir a credencial. Não chegou a completar o movimento, reteve-o uma súbita inquietação, desta vez não foi obra de nenhum anjo da guarda, o que o fez retirar a mão lentamente foi o olhar do farmacêutico, um olhar que mais parecia um estilete, uma broca perfurante, ninguém diria com aquela cara enrugada e aqueles cabelos brancos, o resultado de olhar com tais olhos é pôr logo de pé atrás até a mais ingênua das criaturas, provavelmente por causa disso é que a curiosidade do farmacêutico nunca se dá por satisfeita, quanto mais quer saber menos lhe contam (...) (TN, p. 153; grifos meus).

Ao que parece, o recurso irônico utilizado por Saramago na obra Todos os nomes, assim como em outras de suas obras, tem como função provocar o efeito desestabilizador, ao proporcionar uma visão ambígua da realidade, possibilitando outras leituras de mundo, além da oficial.

Em todos os fragmentos citados se faz presente a convivência e/ou conflito entre o que é considerado oficial e o que é considerado oficioso. É neste jogo que se desenrola a narrativa da obra estudada. Nele parece não haver ganhadores, pois não se trata de um jogo meramente competitivo, marcado pelos pólos contrários, mas parece tratar-se de uma partida sem decisão, em que não há final de jogo. Apenas uma mudança de tática. Aquele que parecia levar desvantagem no primeiro tempo, adquire fôlego e experiência e, no segundo tempo, parece ter descoberto o prazer de jogar, pois já não se vê como um derrotado, porém como alguém capaz de mudar as regras do jogo. Se ele consegue ou não, cabe a nós, leitores, avaliar. 


\section{2- O carnaval na Conservatória}

Como bem lembra o conservador, já que não é possível restituir a vida dos mortos, por que não tentar preservar a memória deles? Para isto, ele adotará uma nova medida na forma de arrumação dos arquivos, sem separar os vivos dos mortos, o que representa, mesmo que simbolicamente, a abolição de fronteiras.

É notório que a narrativa de Todos os nomes vai aos poucos caminhando para o desmoronamento das aparências que envolvem o sistema burocrático. Uma das estratégias para a concretização deste fim é a do recurso irônico, analisado anteriormente, e a outra é a utilização dos elementos da carnavalização, que serão abordados neste tópico.

Em sua obra A cultura popular na Idade Média e no Renascimento, Bakhtin faz uma análise detalhada das diversas manifestações carnavalescas que vigoravam na época de Rabelais. Para ele, a cultura carnavalesca daquela época poderia manifestar-se em três categorias: nas "formas dos ritos e dos espetáculos"; nas "obras cômicas verbais de diversas naturezas orais e escritas, em latim ou língua vulgar"; nas "diversas formas e gêneros do vocabulário familiar e grosseiro" (BAKHTIN, 2008, p. 4).

Para o teórico russo, todas as manifestações típicas da cultura carnavalesca “estão impregnadas do lirismo da alternância e da renovação, da consciência da alegre relatividade das verdades e autoridades no poder. Ela caracteriza-se, principalmente, pela lógica original, das coisas ao avesso, ao contrário, das permutações constantes do alto e do baixo [...] degradações, profanações, coroamentos e destronamentos bufões. $\mathrm{O}$ segundo mundo da cultura popular constrói-se de certa forma como paródia da vida ordinária, como um mundo ao revés [...] todas as coisas e pessoas, o mundo inteiro 
parece cômico e é percebido e considerado no seu aspecto jocoso, no seu alegre relativismo. Quanto à terceira forma de expressão da cultura cômica popular [temos] a abolição provisória das diferenças e barreiras hierárquicas entre as pessoas e a eliminação de certas regras e tabus vigentes na vida cotidiana [...] Era um contato familiar e sem restrições, entre os indivíduos que nenhuma distancia separa mais” (p. 10-14).

Um dos traços carnavalescos na obra Todos os nomes pode ser visto na atitude do conservador em abolir as fronteiras entre os arquivos dos vivos e dos mortos, depois de acompanhar as andanças do Sr. José. Durante o período em que foi cúmplice das atividades ilegais do protagonista, o conservador mudará a sua concepção sobre a forma de organização dos arquivos, passando a acreditar que não havia sentido em separar os arquivos dos vivos e dos mortos. No seu discurso ele alega que esta nova medida fora ocasionada por certos acontecimentos, que o leitor sabe tratar-se das investigações do Sr. José. Além disso, ele tenta justificar a sua decisão como uma forma de tentar preservar a memória dos mortos, ao mantê-los no mesmo arquivo dos vivos. Com isso a sua atitude assemelha-se à de um Deus, ao decidir sobre o lugar que as pessoas deveriam ocupar após a morte. Poder-se-ia, inclusive, conceber como atitude típica de um Deus a prática do Sr. José em promover uma busca que será o motivo da decisão do conservador; e do pastor ao trocar as numerações dos túmulos dos suicidas para que não fossem encontrados e, com isso, praticar uma inversão tipicamente carnavalesca ao transformar a mentira em verdade e, quem sabe, a verdade em mentira. Todas as três personagens do romance agem no sentido de tentar pôr alguma ordem nas coisas do mundo que estão ao alcance delas. O Sr. José saí em busca de informações sobre o verbete de uma anônima, com a qual se sente identificado; o conservador investiga os passos do Sr. José e termina sendo influenciado pelas andanças do auxiliar e, por 
último, o pastor, que age de forma irregular, mas com a conivência dos funcionários do Cemitério, ao trocar as numerações dos túmulos dos suicidas como forma de realizar o desejo destas pessoas.

Dentre as diversas formas de manifestações carnavalescas, a que parece mais comum no romance estudado é aquela relacionada ao realismo grotesco, à qual já foi mencionada neste trabalho. Na Cultura popular na Idade Média e no Renascimento, Bakhtin faz referência à característica marcante do "realismo grotesco", que ele denomina de rebaixamento e que consiste na "transferência ao plano material e corporal, o da terra e do corpo na sua indissolúvel unidade, de tudo que é elevado, espiritual, ideal e abstrato" (BAKHTIN, 2008, p.17).

Numa visão carnavalizada do mundo, da qual o realismo grotesco é representante, não há espaço para o medo, pois este representa uma visão unilateral da realidade, e este medo o riso termina por superar. No mundo carnavalizado também não há fronteiras entre os âmbitos que caracterizam a vida oficial e a oficiosa.

O tema da morte, por exemplo, é encarado pelo realismo grotesco como uma eterna renovação, como um nascimento, e não como um fim em si mesmo: "Nas formas mais altas do realismo grotesco [...] não resta jamais um cadáver, a velhice está grávida, a morte está prenhe, tudo que é limitado, característico, fixo, acabado precipita-se para o inferior corporal para aí ser refundido e nascer de novo" (2008, p. 44).

No romance estudado a morte pode ser concebida sob a óptica do realismo grotesco, na qual ela é encarada não como um ponto final da existência, mas como algo complementar da vida, em que um aspecto não pode ser concebido sem o outro. Para ilustrar esta idéia em Todos os nomes, cite-se a atitude do conservador de decretar a não separação dos arquivos dos vivos e dos mortos, como uma maneira de preservar a memória destes. 
Também na obra Cultura Popular na Idade Média e no Renascimento, Bakhtin analisa a forma como os indivíduos desse período, relacionavam-se com o aspecto oficial e com o oficioso de maneira paralela. Em Todos os nomes, percebem-se alguns pontos em comum com esta forma de encarar a realidade. $\mathrm{Na}$ sua existência oficial, o Sr. José desempenha o seu papel de funcionário da Conservatória Geral, assumindo o compromisso de cumprir as suas obrigações como auxiliar de escrita. Já na sua existência oficiosa, ele é capaz de cometer diversas infrações e viver uma outra realidade, em que ele é quem traça a sua trajetória. Ao seguir a trilha da transgressão, o protagonista, a uma certa altura, não terá mais medo de enfrentar situações de risco, que parecem pôr em perigo a sua reputação como funcionário exemplar da Conservatória. Atitudes que pareciam importantes, tais como a preocupação com a aparência, o cumprimento do horário e das funções de subalterno, numa determinada etapa da narrativa, vão perdendo a sua importância e, no lugar delas vão surgindo outras questões que vão adquirindo relevância. Ou seja, o protagonista começa a viver uma outra realidade, em que vão se interpondo questões consideradas essenciais para a existência humana, como por exemplo, a solidariedade com a solidão alheia, a visão crítica em relação ao tratamento indiferente que o sistema burocrático dispensa aos indivíduos, não se importando se são ou foram felizes. É justamente contra este sistema, que se mostra indiferente em relação às pessoas, que o Sr. José irá rebelar-se ao adotar uma postura mais humanizada com os indivíduos ao seu redor. Neste comportamento solidário do Sr. José pode-se conceber o projeto utópico do Saramago.

A obra Todos os nomes pode ser vista como uma reflexão sobre a realidade contemporânea e sobre o que pode ser feito para se tentar atribuir algum sentido para a existência. E o desafio que esta obra parece propor é o da tomada de atitude em meio a um ambiente hostil como o da Conservatória, onde reina, até um determinado momento 
do romance, a impessoalidade, a injustiça e o controle sobre a vida dos indivíduos, que se vêm regidos pelas conveniências burocráticas.

Tome-se como exemplo a vida do Sr. José, auxiliar de escrita de cinqüenta anos, que vive numa casa acoplada ao prédio da Conservatória. A sua moradia, comparada às proporções ciclópicas da Conservatória, é dotada de uma insignificância tremenda. Porém, existe um detalhe na casa que fará toda a diferença na vida do protagonista. Ela possui uma porta de comunicação com o prédio da Conservatória, porém, o acesso por esta porta foi proibido, quando o Sr. José começou a residir nela. O Sr. José, depois de muitos anos vivendo num lugar que divide a parede com o seu trabalho, resolverá satisfazer uma curiosidade sobre a vida de pessoas célebres. E, depois de tomar uma atitude, ele começará a familiarizar-se com o prédio da Conservatória, de tal maneira que se torna o verdadeiro senhor dos arquivos. Portanto, enquanto se manteve isolado em seu "tugúrio tosco", a vida do Sr. José restringia-se ao cumprimento das suas obrigações burocráticas, pelas quais não era nem recompensado e com as quais sequer se sentia identificado, procurando ocupar o seu tempo livre, fazendo coleção de curiosidade sobre a vida dos famosos. A partir do momento em que resolve entrar pela porta proibida, ele começara a ter seus passos vigiados pelo conservador, que age como um Deus onisciente, que tudo sabe sobre os passos do Sr. José.

No episódio em que o Sr. José usa a porta de comunicação da sua moradia com a Conservatória, ele adota uma postura tipicamente carnavalizada, em que vai sendo abolida, paulatinamente, a separação entre a sua moradia e a Conservatória, elas passam a comunicar-se entre si. E, por fim, esta comunicação será estendida ao Sr. José e o conservador, em que os dois compartilharão das mesmas preocupações e assumirão os papéis que lhes foram reservados - o de conservador e o de senhor dos arquivos. Porém, tanto um quanto o outro não serão mais os mesmos - o conservador passará a ser 
cúmplice do funcionário e este deixará de ser o auxiliar copista e obediente para transformar-se no autor de sua própria história.

A pergunta formulada pela obra Todos os nomes poderia ser: Já que não é possível derrubar a estrutura burocrática em que a nossa sociedade está inserida, pelo menos será que é possível empreender algumas ações que busquem ao menos atribuir algum sentido para a nossa existência.

Em seu ensaio A poética carnavalizada de Augusto dos Anjos, Montgomery José de Vasconcelos faz uma retomada do tema carnavalesco, mais especificamente na obra de Augusto dos Anjos, mas se pode traçar algum paralelo com a obra saramaguiana em questão.

Numa das passagens do ensaio, ele afirma: "pode-se pensar que todos os momentos vividos pelo homem na terra estão cobertos e repletos de carnavalização, pois assim como o cotidiano, cheio de certezas e incertezas, previsibilidades e imprevisibilidades, felicidades e infelicidades, riquezas e misérias, esperanças e desesperos; [a carnavalização] também é a forma de interpretação existencial que mais se assemelha à vida" (VASCONCELOS, 1996, p. 48).

A afirmação acima parece pertinente para o entendimento da postura adotada pelo protagonista da obra Todos os nomes. Na passagem em que o Sr. José invade o colégio onde a desconhecida havia estudado, notam-se alguns traços carnavalescos. Ao descrever o estado do Sr. José quando este retorna da sua visita ao colégio, o narrador faz uso do recurso carnavalesco, como pode-se observar na citação seguinte: (...) O Sr. José sentia dores pelo corpo todo, devia ter os joelhos esfolados, talvez em sangue, o incômodo produzido pela roçadura das calças não queria dizer outra coisa, além disso estava molhado e sujo da cabeça aos pés" (TN, p. 95). 
Tem-se, nesta citação, a imagem denegrida do Sr. José, funcionário exemplar da Conservatória, que, ao mergulhar profundamente em sua busca, chega ao ponto de machucar-se, como o próprio narrador retrata, devido a sua inexperiência em arrombamentos, tal como um ladrão. Na descrição transcrita no parágrafo acima, percebe-se a situação humilhante do Sr. José após ter escalado o colégio. De funcionário da Conservatória ele passará a farrapo humano.

Pode-se associar essa imagem denegrida do Sr. José ao destronamento do rei bufão no carnaval, como parte de uma visão carnavalesca do mundo, à qual se opõe a qualquer idéia de acabamento ou de perfeição. No início da narrativa de Todos os nomes, o protagonista retrata o poder instituído da Conservatória Geral. Sua imagem parece definitiva, porém no transcorrer da narrativa, nota-se que este perfil vai se desfazendo. No episódio citado, anteriormente, da sua invasão ao colégio, onde a desconhecida havia estudado e trabalhado, percebe-se uma outra caracterização da personagem, como se estivesse virado pelo avesso. Ele próprio irá se estranhar, quando se mira no espelho do lavabo, dentro da sala do diretor. A própria personagem parece desconhecer-se, de forma que, se fosse interrogado sobre o motivo da sua invasão ao colégio, ele mesmo talvez não tivesse ainda uma explicação convincente. Veja-se um trecho em que ele dialoga com a sua própria consciência:

E se vem alguém, e se me apanham neste estado, queria dizer nu, chamariam a polícia, por-lhe-iam algemas, perguntar-lhe-iam o nome, a idade e a profissão, primeiro viria o director do colégio, depois apareceria o chefe da Conservatória Geral, e entre os dois olhá-lo-iam com severa condenação, Que faz aqui, perguntariam, e ele não teria voz para responder, não poderia explicar-lhes que andava à procura duma mulher desconhecida, o mais certo era que desatassem todos à gargalhada, e depois tornariam a perguntar, Que faz aqui, e não se calariam com a pergunta até que ele confessasse tudo" (...) (TN, p. 100).

Nesta passagem, o protagonista parece tão receoso da sua atitude, como se estivesse envolvido por um sentimento de culpa, que chega a simular um diálogo com a sua própria consciência e depois terá um sonho em que a pergunta "Que faz aqui" se 
repete inúmeras vezes, até o momento em que acorda, de manhã. Porém, o que interessa é a situação em que ele se vê envolvido com a polícia e algemado. Também se pode pensar numa imagem carnavalesca do protagonista, em que se tem contato com sua outra faceta, totalmente diferente daquela que assumia no início da obra, em que reproduzia o poder instituído.

Outra passagem em que se percebe o enfoque carnavalesco da narrativa aparece na descrição do colégio, em que o narrador vê as salas de aulas e objetos contidos nela de uma forma grotesca, com as "carteiras dos alunos" se assemelhando a túmulos, a "mesa do professor" parecendo um lugar onde se realizavam os sacrifícios e o "quadro negro", o local onde se faziam os acertos.

Nesta descrição do espaço escolar, percebe-se o senso crítico na ironia do narrador, ao fazer uma comparação de um local que deveria se assemelhar à vida, assemelhando-se mais a um lugar de morte, como um cemitério. Nesta metáfora, está evidente uma crítica ao sistema escolar, como um reflexo da sociedade burocrática. Este reflexo torna-se visível na própria disposição dos lugares, em que as carteiras estão voltadas para a mesa do professor, visto como único detentor do saber, e o "quadro negro" visto como o local de que se utiliza para julgar aqueles que se pressupõem como carentes do conhecimento.

Além disso, observa-se a maneira como se dá o contato dos alunos com os lugares e com as partes do corpo humano, como se fosse possível as pessoas se conhecerem desta forma. Este trecho da descrição da escola aborda a situação fragmentada do próprio conhecimento, em que a figura do professor é vista como aquele que possui o poder e os alunos como aqueles que nada sabem. Esta visão maniqueísta do mundo, novamente faz pensar na visão de mundo unilateral que o narrador saramaguiano denuncia em Todos os nomes. A escola, nesse sentido, também representa 
outro espaço burocrático retratado pela obra. De forma que se pode comparar o papel do professor com aquele assumido pelo conservador. $\mathrm{O}$ próprio narrador intervém para defender as semelhanças entre as duas instituições - a Conservatória e a Escola, mesmo que, à primeira vista, parecessem diferentes: “(...) Provavelmente, quanto maior é a diferença, maior será a igualdade, e quanto maior é a igualdade, maior a diferença será, naquele momento ainda não sabia até que ponto estava na razão (...)” (TN, p. 97)

De forma semelhante ao conservador, a figura do professor é traçada em Todos os nomes como aquele que detém o poder e os alunos como aqueles que lhe devem obediência. Outra semelhança entre a Conservatória e a Escola pode ser vista nas relações de poder entre os próprios alunos - em que uns detêm o conhecimento e outros não. No caso da Conservatória as relações de poder são estabelecidas através das funções exercidas pelos funcionários, em que os que detêm os cargos considerados mais importantes exercem o domínio sobre os demais:

(...) olhou para dentro das salas [...] onde as carteiras dos alunos pareciam túmulos alinhados, onde a mesa do professor era como um sombrio espaço de sacrifício, e o quadro negro o lugar onde se faziam as contas de todos. Viu, suspensos das paredes, como se fossem as manchas confusas que o tempo vai deixando atrás de si na pele dos seres e das coisas, os mapas do céu, do mundo e dos países, as cartas hidrográficas e orográficas do ser humano, a canalização do sangue, o trânsito digestivo, a ordenação dos músculos, a comunicação dos nervos, a armação dos ossos, o fole dos pulmões, o labirinto do cérebro, o corte do olho, o enredo dos sexos (...). (TN, p. 96-97).

Portanto, a escola, numa visão carnavalizada pelo narrador em Todos os nomes, assemelha-se ao cemitério, enquanto este estabelecimento é visto como "espécie de biblioteca, onde o lugar dos livros se encontrasse ocupado por pessoas enterradas (...) (TN, p.230)". Tem-se nestes dois exemplos - o da escola e o do cemitério - uma típica inversão carnavalesca, em que o lugar do suposto conhecimento é rebaixado à categoria de cemitério, depósito de corpos destituídos de vida, enquanto o cemitério é visto como uma biblioteca e, portanto local de elevação do saber intelectual. 
Dentre outros rebaixamentos presentes em Todos os nomes, pode-se citar o episódio em que o Sr. José, depois de inspecionar toda a escola à procura de informações sobre a desconhecida, começa a demonstrar sinais de exaustão e desabafa o seu nervosismo diante da situação tensa que estava a presenciar. Neste momento nota-se o tom de rebaixamento com que o narrador descreve a situação, como se o funcionário da Conservatória, de repente tivesse se descontrolado, desatando a chorar como uma criança:

(...) Não agüento mais, pensou, e sem se poder conter de pura exaustão nervosa, começou a soluçar, um choro desatado, quase convulsivo, ali de pé, como se tivesse voltado a ser, noutra escola, o rapazinho das primeiras classes que cometeu uma travessura e foi chamado ao director para receber o merecido castigo (TN, p. 98-99)

Na citação anterior há mais um exemplo de rebaixamento, que constitui uma das características do realismo grotesco, que ainda se dá no episódio da invasão da escola. Reconhece-se mais uma visão grotesca do mundo no rebaixamento do Sr. José, o que pode ser notado pelo estado deprimente em que se encontrava neste momento em que as suas vestes assemelhavam-se a farrapos. Este episódio também pode ser visto como um típico destronamento, em que o auxiliar de escrita da Conservatória, figura respeitável, cumpridora de seus deveres e porta-voz da instituição, é destituído de seu uniforme e parece transfigurado perante si mesmo e perante o leitor:

(...) Largou a gabardina molhada para o chão, tirou o lenço do bolso das calças e levou-o aos olhos, mas o lenço estava tão molhado como o resto, toda a sua pessoa, desde a cabeça aos pés, percebia-o agora, era como se estivesse a ressumbrar água, como se ele não fosse mais do que um esfregão torcido, sujo o corpo, magoado o espírito, e ambos infelizes (...) (TN, p.99).

Também a escola em que a desconhecida havia estudado e trabalhado é descrita sob a óptica do realismo grotesco, aparecendo rebaixada à condição de espaço onde se 
vivem seres insignificantes, como os insetos que se adequam à falta de comida do local.

Nestes locais em que a escassez predomina, somente os insetos e parasitas tem condições de sobreviver:

(...) o Sr. José reparou que se tinha criado no sótão um grande silêncio, como se o silêncio que havia antes contivesse um silêncio maior, seriam os bichos da madeira que tinham interrompido a sua actividade escavadora. Do tecto pendiam teias de aranhas negras de pó, as proprietárias deviam ter morrido há muito tempo por falta de comida, não havia aqui nada que pudesse atrair uma mosca perdida, de mais a mais com a porta fechada em baixo, e as traças do papel, os peixinhos de prata, tal como caruncho nos vigamentos, não tinham qualquer motivo para trocar pelo mundo exterior as galerias de celulose onde viviam (...) (TN, p. 110)

Na sua abordagem sobre os aspectos carnavalescos, Bakhtin analisa todo tipo de imagens grotescas, dentre elas a do destronamento. Neste processo acontece o rebaixamento do "bufão [que] é o rei do mundo às avessas" [...]. "O rebaixamento é, enfim, o princípio artístico essencial do realismo grotesco: todas as coisas sagradas e elevadas aí são reinterpretadas no plano material e corporal” (...) (BAKHTIN, 2008, p. $325)$.

No romance estudado, é possível identificar, na figura do protagonista, a imagem do rei bufão. O Sr. José, no decorrer da narrativa, irá se tornar o verdadeiro "senhor dos arquivos", porém a sua realeza é de outra ordem, ou seja, a do avesso. A lógica da sua trajetória é inversa à do mundo oficial. Pode-se arriscar a seguinte afirmação: a de que o Sr. José transformar-se-á no "rei do mundo às avessas" pois a sua busca prende-se à tentativa de desvendar o mistério que está por trás das aparências. Para isto ele tem que percorrer um mundo oficioso e enfrentar uma série de riscos.

Pode-se afirmar que, dentre os aspectos abordados sob a óptica do rebaixamento, vêem-se com destaque o sistema burocrático das instituições como a Conservatória Geral do Registro Civil, a Escola e o Cemitério Geral. Tudo isto através das ações oficiosas do protagonista do romance. Em relação à Conservatória Geral, vê-se o uso ilegal que faz o Sr. José dos arquivos para usufruto próprio, inicialmente, e que depois 
irá adquirir uma repercussão enorme, ao servir de pretexto para as mudanças substanciais na organização dos arquivos.

A Conservatória também será mostrada pelo viés do realismo grotesco através do submundo dos pequenos bichos que lá vivem, assim como o episódio do pesquisador que, após perder-se entre os arquivos dos mortos, teve que se manter vivo ingerindo quantidades enormes de papéis dos arquivos, já em estado de decomposição.

Uma das caracterizações grotescas do prédio da Conservatória pode ser vista na passagem em que o Sr. José realiza uma inspeção nos arquivos dos mortos em meio à escuridão. Neste trecho da obra Todos os nomes, são descritos os microorganismos que habitam o acervo. Esta descrição também permite associar a imagem dos papéis velhos dos arquivos dos mortos com os próprios corpos em decomposição, o que sugere a aproximação de algo aparentemente estéril como os papéis em estado de deterioração com os corpos em estado de putrefação. Ou seja, tem-se a imagem da aproximação de um arquivo burocrático, com o princípio da morte, que também é visto como retorno a vida:

(...) aventurar-se sozinho, no meio duma negra noite, por estas catacumbas da humanidade dentro, cercado de nomes, ouvindo o sussurrar dos papéis, ou um murmúrio de vozes, quem os poderá distinguir [...]. O Sr. José detesta esta bicharada, que à primeira vista se diria ter sido posta no mundo para ornamentar, da mesma maneira que detesta os peixes-de-prata que também por aqui proliferam [...], Quanto à rataria, nem vale a pena falar do destruidora que é. (...) (TN, p. 169-170)

O trecho a seguir apresenta a descrição do ambiente estéril da Conservatória. Esta caracterização da Conservatória como um ambiente estéril alude à ausência de ingredientes necessários para uma existência plena. Esta visão era preponderante antes do processo de autoconsciência tanto do Sr. José quanto do conservador. Poder-se-ia, portanto, associar a idéia da aridez ao sentido da falta de vida. Fazendo-se uma 
aproximação com o aspecto ideológico, ficará clara a postura autoritária da instituição em impor uma visão monológica da realidade, ao impor o poder dominante sobre os demais indivíduos:

(...) A um observador desprevenido poderá surpreender como aqui não se multiplicaram as colônias de ratos até ao devoramento total dos arquivos, sobretudo considerando a impossibilidade mais do que patente duma desinfestação cem por cento eficaz. A explicação, ainda que haja quem alimente algumas dúvidas sobre a sua total pertinência, estaria na falta de água ou de uma suficiente humidade ambiente, estaria na dieta seca a que os bichos se encontram sujeitos pelo meio em que escolheram viver ou aonde a má sorte os trouxe, do que teria resultado um atrofiamento notório da musculatura genital com conseqüências muito negativas no exercício da cópula (...) (TN, p. 171).

Quanto à descrição do Cemitério, a carnavalização se constata pela inexistência de muros que separam as sepulturas dos transeuntes, o que remete à abolição de fronteiras entre o mundo dos vivos e dos mortos. Para comunicar a imagem do Cemitério como um local onde mortos e vivos convivem diariamente, o narrador faz uma comparação metafórica dele com uma árvore real em que "se confundem as avezinhas e as folhagens." Ao visitá-lo, com a intenção de desvendar os mistérios que envolviam a morte da desconhecida, o Sr. José perceberá muitas semelhanças com a Conservatória. Além disso, o narrador menciona que a atitude do conservador em unificar os arquivos dos vivos e dos mortos constituiu uma iniciativa própria, sem nenhuma relação com o procedimento do curador do cemitério, que adotou esta forma de organizar as sepulturas sem separá-las dos vivos.

Diante destas premissas, conclui-se que, apesar da semelhança entre o Cemitério e a Conservatória, principalmente no que concerne à fachada, assim como nas funções exercidas pelos funcionários, estes dois espaços têm algumas peculiaridades que os diferenciam. Dentre elas, como já se disse acima, a ausência de fronteiras entre os mortos e os vivos. Portanto, pode-se pensar que existe uma espécie de inversão 
carnavalesca entre o Cemitério e a Conservatória, em que, no primeiro, serão abolidas as fronteiras entre a vida e a morte, simbolizada pela ausência de muros ao redor, enquanto que, na Conservatória do início da obra, tem-se a separação entre a vida e morte, simbolizada pela arrumação dos arquivos dos vivos e dos mortos, que ocorre de forma isolada. Somente no final do romance é que serão abolidas as barreiras entre os dois arquivos, dos vivos e dos mortos, através da nova medida anunciada pelo conservador em seu discurso, do qual segue a transcrição de um pequeno trecho:

(...) Ouso dizer que precisamente está mesma necessidade de higiene física e de sanidade mental deverá determinar que nós os da Conservatória Geral do Registo Civil, nós os que escrevemos e movemos os papéis da vida e da morte, reunamos em um só arquivo, a que passaremos a chamar simplesmente histórico, os mortos e os vivos, tornando-os inseparáveis neste lugar, já que lá fora a lei, o costume e o medo não o consentem. (“...)” (TN, p. 209)

Outro aspecto importante a ser retratado prende-se ao comportamento do protagonista, tal como abordado pelo narrador. Podem-se traçar algumas semelhanças entre a figura do Sr. José e a figura do bobo, da obra $O$ idiota de Dostoievski, estudada por Bakhtin em Problemas da poética de Dostoiévski. A figura do Sr. José é descrita de uma forma que beira o ridículo, muitas vezes. Porém, como já se confirmou neste trabalho, o protagonista deve ser visto como um ser inacabado e, portanto, capaz de adotar posturas inesperadas.

Enquanto o Sr. José manteve-se ligado ao poder burocrático, representado pela Conservatória e pelo seu representante máximo, o conservador, ele foi muitas vezes caracterizado como alguém totalmente insignificante, com um campo de visão restrito, isolado do mundo, sem amigos, sem família e a única coisa que sabia fazer era o serviço burocrático da Conservatória. O narrador, muitas vezes, se refere à personagem como um indivíduo desengonçado e de horizontes estreitos, que se contentava em residir 
numa pequena habitação acoplada ao prédio da Conservatória, obedecer às ordens dos seus superiores sem questioná-las e colecionar curiosidades sobre a vida de pessoas famosas. $\mathrm{Na}$ passagem seguinte pode-se observar esse tratamento dispensado ao protagonista:

(...) O Sr. José está a ser ridículo, mas não se importa, só ele é que sabe a que ponto é absurdo e disparatado o que está a fazer, ninguém o poderá ver a arrastar-se por esta escada acima como um lagarto ainda mal acordado da hibernação, agarrado ansiosamente aos degraus, um após outro, o corpo procurando acompanhar a curva helicoidal que parece nunca mais acabar, os joelhos outra vez martirizados (TN, p. 108).

Ainda quando se encontrava no colégio à procura dos verbetes da desconhecida, o protagonista, a certa altura da sua procura é descrito desta forma: “(...) O Sr. José levantou-se, inutilmente tentou sacudir o pó das calças e da camisa, a cara parecia a de um palhaço extravagante, com uma grande mancha num lado só (...)” (Id., p. 110).

Estas caracterizações do Sr. José, apontadas neste tópico do trabalho, fazem parte de uma cosmovisão carnavalesca do mundo, que constitui uma das estratégias de Saramago na problematização da realidade vivenciada pelo protagonista. 


\section{Conclusão}

A partir da análise do recorte temático da obra Todos os nomes, de José Saramago, apresentada neste trabalho, acerca da autoconsciência do Sr. José e do seu duplo, o conservador, foi possível verificar que o romance estudado constitui-se numa viagem do protagonista em busca da construção de sua identidade e, por extensão, da identidade do conservador.

Nesse processo, inclusive, pôde-se perceber que existe um projeto utópico com o qual o próprio autor parece compartilhar. Em outras palavras, ao longo da narrativa o dinamismo da ação envolveu sempre, explícita ou implicitamente, como realidade ou como projeto, a possibilidade de reconstrução tanto da sociedade (concebida a partir das microesferas de poder, como a Escola, a Conservatória, o Cemitério) quanto da forma como se estabelecem, nela, as relações de poder entre as pessoas.

Nesse sentido, foi útil o recurso às teorias de Foucault sobre a construção do espaço da vigilância e sobre os procedimentos para vigiar e punir. Foi possível constatar, por exemplo, que a arquitetura da Conservatória e a composição do ambiente de trabalho representam figurativamente a estratégia disciplinar dos aparelhos institucionais da sociedade que Saramago quer colocar em xeque.

Além disso, o mesmo instrumental teórico contribuiu para se visualizar melhor o percurso do Sr. José desde a sua vida alienada, durante o dia na Conservatória e à noite na solidão da sua pobre casa (extensão do ambiente de trabalho), até o período em que, iniciando sua investigação, começa a conhecer outras pessoas.

De fato, durante o percurso "iniciático" do protagonista, os contatos que estabelece com as diversas pessoas e com as mais diferentes intenções constituíram as suas primeiras relações dialógicas com o outro e, apesar de, muitas vezes, ter buscado 
“imitar" o discurso autoritário e monológico do conservador (representação do poder instituído), o resultado foram trocas humanas que redundaram em crescimento recíproco.

Assim, usando como orientação teórica os conceitos de Foucault e Bakhtin sobre as relações de poder, a trajetória do Sr. José em busca da mulher desconhecida ou, quando muito, dos dados a seu respeito acabou por ser compreendida como um embate de forças embate este que envolve aspectos negativos e positivos, que levam à mudança e humanização das relações entre o Sr. José e o conservador no desfecho da narrativa.

As idéias de Bakhtin acerca da personagem contribuem para que se compreenda a figura do Sr. José como um herói ideólogo, que necessita conviver com as duas esferas da existência - a do poder oficial com o seu revés, suas práticas oficiosas. A primeira instância aparece representada no romance pela Conservatória e pelo seu representante, o conservador. Já a segunda, que abrange todos os espaços por onde o protagonista se aventurou para satisfazer seu objetivo de vida (encontrar a mulher anônima), pertence ao meio oficioso com que o Sr. José vai aprendendo a lidar, como forma de emancipar-se da situação alienante em que se via inserido.

Foi possível constatar que a postura adotada pelo herói é tanto de reprodução quanto de desconstrução do poder instituído (representado, como se pôde ver, principalmente pela Conservatória Geral do Registro Civil). A reprodução pode ser vista na atitude de atrelamento do herói a este poder, na primeira parte do romance, em que agia como um simples reprodutor do poder burocrático. Além disso, nota-se que Saramago faz uso do recurso alegórico como forma de envolver a temática da busca numa aura de mistério e de surpresas.

Mesmo o início da obra não pode ser interpretado de forma unilateral, como se, de uma hora para outra, o Sr. José negasse a tradição em cujo ambiente vivia há tanto 
tempo para passar a adotar posturas tidas como suspeitas. $\mathrm{O}$ que ocorre na narrativa de Todos os nomes é que, desde o começo, o protagonista, e depois o seu duplo, o conservador, agem nas fronteiras entre o poder oficial e suas práticas oficiosas.

A figura do Sr. José pode ser vista, além disso, como a do herói inconcluso, que, ao mesmo tempo que age como funcionário submisso, também adota posturas irregulares, que exigem dele um desempenho vigoroso. O Sr. José passa a ter duas vidas - uma pertencente à oficialidade e outra ligada ao submundo da falsificação, do assalto e da dissimulação. Nesta fase da sua trajetória, ele já não receia tanto ser descoberto, pois, aos poucos, vai perdendo o medo. Portanto, nesta etapa da narrativa, o protagonista reage a sua condição de alienado em relação ao sistema burocrático e começa a fazer uso do poder para usufruto próprio e para romper com as amarras que o tolhiam. Ao percorrer a sua trajetória de busca pela mulher desconhecida, o Sr. José vai adquirindo a sua autoconsciência, juntamente com o seu duplo - o conservador, que também possui uma atuação importante na obra, ao pôr em prática uma nova forma de organização dos arquivos, sem distinção de fronteiras entre o mundo dos vivos e dos mortos.

O processo da busca do Sr. José não acarreta o achamento da mulher desconhecida, como ele previa inicialmente; o seu ganho pertence a uma outra categoria, pois ele adquire a sua autoconsciência, o que, conseqüentemente, promoverá a maior inversão carnavalesca da obra - a abolição de fronteiras entre os arquivos dos vivos e dos mortos.

A autoconsciência do Sr. José somente será adquirida a partir do momento em que ele trava relações dialógicas com outros indivíduos no transcorrer da narrativa. Somente desta forma ele vai assumindo o seu papel de sujeito no seu processo de 
libertação das amarras em que se via aprisionado, transformando-se em autor da sua própria história.

Como já foi dito, é possível conceber Todos os nomes como uma busca utópica, em que, mais importante do que se encontrar a mulher desconhecida, é a procura de possibilidades de relações mais humanizadas entre os indivíduos, mesmo que, para isto, seja necessária a prática de atividades consideradas irregulares sob a óptica de quem está no papel de autoridade.

Ao invés de um mundo dividido em fronteiras hierárquicas, em que se defende a sobreposição de um olhar sobre outro, o romance estudado propõe o diálogo entre as diversas formas de se conceber a realidade. Neste sentido, colaboram a visão irônica do narrador e o recurso carnavalesco presentes no romance.

A visão irônica do narrador de Todos os nomes deve ser concebida como uma das estratégias usadas pelo autor para a carnavalização do próprio discurso, tal como se lê no estudo de Beth Brait sobre a ironia, que foi usado como base teórica para o desenvolvimento do quarto capítulo deste trabalho. A ambigüidade do discurso irônico impede que o leitor tenha uma visão única da realidade e, ao mesmo tempo, auxilia-o no sentido de relativizar valores, posições e conceitos que eram até então apreendidos de forma cristalizada.

A carnavalização também pôde ser vista em Todos os nomes na forma de conceber certas atitudes em que são abolidas, mesmo que de forma temporária, as diferenças hierárquicas entre as pessoas e a eliminação de certas normas existentes na sociedade. Percebe-se no romance estudado que várias são as passagens em que tanto o Sr. José quanto o conservador agem de forma a desrespeitar a posição hierárquica e a praticar transgressões contra o poder instituído. Todas estas atitudes devem ser vistas como integrantes do processo de autoconsciência das duas personagens. 
A partir do estudo da obra Todos os nomes, de José Saramago, pode-se concluir que a busca empreendida pelo protagonista não possui um caráter utilitário e imediato, mas pode ser vista como alegoria da própria existência humana. Além disso, é possível se pensar num projeto utópico do escritor, ao conceber a realidade de uma maneira em que se torna possível uma relação dialógica entre o poder oficial e o ofícioso, como forma de se encarar o mundo numa perspectiva humanizadora.

Espera-se que este trabalho possa contribuir, mesmo que de forma tímida, para os estudos relacionados à obra Todos os nomes, de José Saramago, assim como para as demais obras do autor. O estudo desta obra abarca outras abordagens, além das realizadas neste trabalho, porém na impossibilidade de desenvolvê-las nesta oportunidade, fica a sugestão para a sua retomada em futuras ocasiões. 


\section{BIBLIOGRAFIA}

\section{DE JOSÉ SARAMAGO}

SARAMAGO, José. O Ano da morte de Ricardo Reis. São Paulo: Companhia das Letras, 1984.

. O Ano de 1993. Lisboa: Editorial Caminho, 1987.

Caminho, 1990.

. Os apontamentos: Crônicas Políticas. 2.ed. Lisboa: Editorial Caminho, 1986.

. A bagagem do viajante: crônicas, 2.ed. Lisboa: Editorial . A Caverna. São Paulo: Companhia das Letras, 2000.

. A jangada de pedra. Lisboa: Editorial Caminho, 1986.

. A noite. 2.ed. Lisboa: Editorial Caminho, 1979.

Caminho, 1987.

- A segunda vida de Francisco de Assis. Lisboa: Editorial 2005.

. As intermitências da morte. São Paulo: Companhia das Letras, . Cadernos de Lanzarote. São Paulo: Companhia das Letras, 1997.

. O conto da ilha desconhecida. Lisboa: Assírio Alvim, 1997.

Caminho, 1985.

. Deste mundo e do outro. Crônicas. 3.ed. Lisboa: Editorial . Ensaio sobre a cegueira. 2.ed. Lisboa: Editorial Caminho, 1994.

2004.

Ensaio sobre a lucidez. São Paulo: Companhia das Letras, 
SARAMAGO, José. História do cerco de Lisboa. São Paulo: Companhia das Letras, 1989.

. In nomine dei. Teatro. São Paulo: Companhia das Letras, 1993.

. Levantado do chão. São Paulo: Difel, 1982.

. Manual de Pintura e Caligrafia. São Paulo: Companhia das

Letras, 1992.

. Memorial do convento. São Paulo: Difel, 1983.

. Objecto Quase. Lisboa: Moraes, 1977.

. O Evangelho segundo Jesus Cristo. São Paulo: Companhia das

Letras, 1991.

.O Homem duplicado. São Paulo: Companhia das Letras, 2002.

. Os poemas possiveis. Lisboa: Editorial Caminho, 1982.

. Poética dos cinco sentidos. O ouvido. Lisboa: Bertrand, 1979.

1985.

. Provavelmente Alegria: Poesia. 2.ed. Lisboa: Editorial Caminho, . Que farei com este livro? 2.ed. Lisboa: Editorial Caminho, 1980.

. Terra do Pecado. Romance. Lisboa: Editorial Caminho, 1997.

. Todos os nomes. São Paulo: Companhia das Letras, 1997.

.Viagem a Portugal, Lisboa: Editorial Caminho, 1994. 


\section{ARTIGOS SOBRE JOSÉ SARAMAGO E SUA OBRA EM JORNAIS E REVISTAS}

ALFAYA, Javier- O compromisso moral e politico na obra de José Saramago ou um leitor espanhol perante Saramago. Lisboa, Vértice 52 (jan./fev.93), p.23-27

COSTA, Horácio. "Sobre a pós-modernidade em Portugal Saramago revisita Pessoa". In: Revista Colóquio Letras, n. 120, Lisboa, abril/junho, p.41-48.

COSTA, Linda Santos. O mundo segundo Saramago. Lisboa, Público (11 nov. 2000) Mil Folhas, p.4-5.

DEL RIOS, J; ALBUQUERQUE, B; LAUB, M. "A terceira palavra de Saramago". In: Bravo !, ano 2, $\mathrm{n}^{\circ} 21$, p. 60-69, jun. 1999.

MONGELLI, Lênia Márcia. José Saramago no encalço de vidas anônimas. Jornal da Tarde. 15 novembro de 1997. Caderno de Sábado, p.6.

MOURÃO, José Augusto. A litote do insuportável. Literatura e Poder. Lisboa, (primav./verão 97), n.38., p.46-51.

PERRONE - MOISÉS, Leyla. As artemages de Saramago. São Paulo, Folha de São Paulo, 6 dez 98, Caderno Mais, p 8-9.

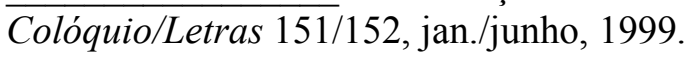

- A ficção como desafio ao Registro Civil. Lisboa,

SCHWARTZ, Adriano. A angústia da seqüencia. Folha de São Paulo, 13 de dezembro, 1997. Jornal de Resenhas, p.7.

. O mito do cotidiano de Saramago. São Paulo, Folha de São Paulo, 18 nov.2000, Ilustrada, p. 6.

SOARES, Alessandro. O outro eu segundo Saramago. Diário do Grande ABC, Santo André, 07 de novembro, 2002. Cultura\&Lazer, p.3. 


\section{SOBRE JOSÉ SARAMAGO E SUA OBRA}

ALLEMAND OLIVEIRA, Lúcia Maria de. Tempo e Voz: O percurso trágico ideológico na narrativa de José Saramago. 1996. Tese de Doutorado. Faculdade de Filosofia, Letras e Ciências Humanas, Universidade de São Paulo, São Paulo.

BAPTISTA-BASTOS. José Saramago. Aproximação a um retrato. Lisboa: Dom Quixote, 1996.

BASTAZIN, Vera. Mito e Poética na Literatura Contemporânea. Um estudo sobre José Saramago. Cotia, São Paulo: Ateliê, 2006.

BERRINI, Beatriz. Ler Saramago: O romance. Lisboa: Editorial Caminho, 1998. . José Saramago: uma homenagem. São Paulo: EDUC, 1999.

BRAGA, Miriam Rodrigues. A concepção de língua de Saramago - confronto entre o dito e o escrito. São Paulo, Arte \& Ciência, 1999.

CALBUCCI, Eduardo. Saramago - um roteiro para os romances. São Paulo: Ateliê, 1999.

COSTA, Horácio. José Saramago. O período formativo. Lisboa: Editorial Caminho, 1997.

FERREIRA, Sandra Aparecida. Da estátua à pedra: A fase universal de José Saramago. 2004. Tese de Doutorado. Faculdade de Filosofia, Letras e Ciências Humanas, Universidade de São Paulo, São Paulo.

FRANÇA, Maria José. A tessitura do Avesso. Ensaio sobre a Cegueira, Todos os Nomes e A Caverna, de José Saramago, na mira da sátira menipéia. 2001. Tese de Doutorado. Faculdade de Filosofia, Letras e Ciências Humanas, Universidade de São Paulo, São Paulo. 
GOBBI, Márcia Zamboni. De fato, Ficção. 1997. Tese de Doutorado. Faculdade de Filosofia, Letras e Ciências Humanas, Universidade de São Paulo, São Paulo.

GOMES, Álvaro Cardoso. A voz itinerante. São Paulo: Edusp, 1993.

LOPONDO, Lílian (org.) Saramago segundo terceiros. São Paulo: Humanitas, 1998.

OLIVEIRA Filho, Odil José de. Carnaval no convento: intertextualidade e paródia em José Saramago. São Paulo: Editora da Universidade Estadual Paulista, 1993.

PERRONE-MOISÉS, Leyla. "Formas e usos da negação na ficção histórica de José Saramago". In: CARVALHAL, Tania F. e TUTIKIAN, Jane (organizadoras). Literatura e história: três vozes de expressão portuguesa. Porto Alegre: Editora da Universidade Federal do Rio Grande do Sul, 1999.

PENHA, Gisela Maria de Lima B. A Jangada de Pedra - Uma viagem alegórica à poética de José Saramago. São Paulo: Editora UNESP, 2007.

REIS, Carlos. Diálogos com José Saramago. Lisboa: Editorial Caminho, 1998.

. "Romance e História depois da Revolução. José Saramago e a ficção portuguesa contemporânea." In Marie Hélène Piwnic (org.) La Littérature Portugaise: Regards Sur Deux Fins de Siècle (XIX-XX). Bordeaux: Maison des pays ibériques, 1996.

ROANI, Gerson Luiz. No limiar do texto: literatura e história em José Saramago. São Paulo: Annablume, 2002.

SANTOS, Rosemary Conceição dos. A recepção crítica de Todos os nomes e $O$ homem duplicado. 2006. Tese de Doutorado. Faculdade de Filosofia, Letras e Ciências Humanas, Universidade de São Paulo, São Paulo.

SEIXO, Maria Alzira. O essencial sobre José Saramago. São Paulo: SL: INCM, 1987.

. Lugares da ficção em José Saramago. Lisboa: Imprensa Nacional. Casa da Moeda, 1999. 
SEIXO, Maria Alzira. "Saramago e o tempo da ficção". In: CARVALHAL, Tania F. e TUTIKIAN, Jane (Organizadoras). Literatura e história: três vozes de expressão portuguesa. Porto Alegre: Ed. Universidade/ UFRGS, 1999.

SILVA, Teresa Cristina Cerdeira da. José Saramago entre a história e a ficção. Uma saga de Portugueses. Lisboa: Publicações Dom Quixote, 1989.

SILVEIRA, Francisco Maciel. Saramago: - Eu próprio, o outro? Aveiro: Editora da Universidade de Aveiro, 2007.

VENÂNCIO, Fernando. José Saramago: A luz e o sombreado. Porto: Campo das Letras, 2000.

\section{BIBLIOGRAFIA GERAL}

ABELAIRA, A. Quatro paredes nuas. Lisboa: Betrand, 1972.

AGUIAR e SILVA, Vitor Manuel. Teoria da literatura. 5.ed. Coimbra: Almedina, 1983.

AMALFI, Francis. A oficina dos escritores. Inspirações sobre a arte de escrever, a literatura e a vida. Tradução do espanhol de Fernanda Semedo. Lisboa: Editorial Estampa, 2007.

AMORA, Antônio Soares. Introdução à teoria da literatura. 13.ed. São Paulo: Cultrix, 2006.

ARENDT, Hannah. O Sistema Totalitário. Tradução de Roberto Raposo. Lisboa: Publicações Dom Quixote, 1978.

ARISTÓTELES. Poética. Tradução, prefácio, introdução, comentários e apêndices de Eudoro de Souza. Lisboa: Imprensa Nacional - Casa da Moeda, 1986.

BAKHTIN, Mikhail. A Cultura Popular na Idade Média e no Renascimento: O contexto de François Rabelais. Tradução de Yara Frateschi Vieira. 6.ed. São Paulo: Hucitec/Brasília: UNB, 2008. 
BAKHTIN, Mikhail. (V.N. Volochinov). Marxismo e Filosofia da Linguagem. Problemas fundamentais do método sociológico na ciência e na linguagem. Tradução de Michel Lahud et al.7.ed. São Paulo: Hucitec, 1995.

. Problemas da Poética de Dostoiévski. Tradução Paulo Bezerra. 3.ed. Rio de Janeiro: Forense Universitária, 2005.

.Questões de literatura e de estética. A Teoria do romance. Tradução de Aurora F. Bernadini [et al.]. 5.ed. São Paulo: Edunesp/Hucitec, 1988.

BARROS, Diana e FIORIN, José Luiz (Orgs.). Dialogismo, polifonia, Intertextualidade. São Paulo: Edusp, 1994.

BARTHES, Roland [et al.]. Análise estrutural da narrativa. Tradução de Maria Zélia B. Pinto. Petrópolis: Vozes, 1971.

- Novos Ensaios Críticos seguidos de O Grau zero da escritura. Tradução de Heloysa de Lima Dantas [et al.] São Paulo: Cultrix, 1971.

BENJAMIN, Walter. A modernidade e os modernos. Tradução de Heindrum K.Mendes da Silva [et al.]. Rio de Janeiro: Tempo Brasileiro, 1975.

BERGER, Peter e LUCKMANN, Thomas. A construção social da realidade. Tradução de Souza Fernandes. Petrópolis: Vozes, 1985.

BERGSON, Henri. O Riso. Tradução de Miguel Serras Pereira. Lisboa: Relógio D’água, 1991.

BERMAN, Marshall. Tudo que é sólido desmancha no ar: a leitura da modernidade. Tradução de Carlos F. Moisés e Ana Maria L. Ioriatti.São Paulo: Companhia das Letras, 1986.

BOOTH, Wayne. A retórica da ficção. Tradução de Maria Teresa H. Guerreiro. Lisboa: Arcádia, 1980.

BRAIT, Beth. A personagem. 3.ed. São Paulo: Ática, 1987. .(org.). Bakhtin: conceitos-chave. 2.ed. São Paulo: Contexto, 2005. 
BRAIT, Beth. Bakhtin: outros conceitos-chave. São Paulo: Contexto, 2006. Unicamp, 1997.

Bakhtin, dialogismo e construção de sentido. Campinas: Editora da . Ironia em perspectiva polifônica. Campinas: Editora da Unicamp, 1996.

CANDIDO, Antonio [et ali.]. A personagem de ficção. São Paulo: Perspectiva, 1970.

CANETTI, Elias. Massa e poder. Tradução de Sérgio Tellaroli. São Paulo: Companhia das Letras, 1995.

CHARAUDEAU, Patrick. Discurso político. Tradução de Fabiana Komesu e Dilson F. da Cruz. São Paulo: Contexto, 2006.

CHAUÍ, Marilena. Simulacro e poder. São Paulo: Fundação Perseu Abramo, 2006.

CHEVALIER, Jean e GHEERBRANT, Alain. Dicionário de Símbolos. Tradução de Vera Costa e Silva [et al.]. Rio de Janeiro: José Olympio, 2005.

CLARK, Katerina \& HOLQUIST, Michael. Mikhail Bakhtin. Tradução do Inglês por Jacob Guinsburg. São Paulo: Perspectiva, 1998.

CONNOR, S. Cultura pós-moderna. Introdução às teorias do contemporâneo. Tradução de Adail Ubirajara Sobral e Maria Stela Gonçalves. 2. ed. São Paulo: Loyola, 1993.

ECO, Umberto. Obra Aberta: forma e indeterminação nas poéticas contemporâneas. Tradução de Giovanni Cutolo. 9.ed. São Paulo: Perspectiva, 2005.

FARACO, Carlos Alberto. Linguagem e Diálogo. As idéias lingüísticas do Círculo de Bakhtin. Curitiba: Criar, 2003.

FONSECA, Márcio Alves da. Michel Foucault e a constituição do sujeito. São Paulo: EDUC, 2003. 
FOUCAULT, Michel. Microfísica do poder. Tradução de Roberto Machado. 20.ed. Rio de Janeiro: Graal, 1979.

- Vigiar e punir. Tradução de Raquel Ramalhete. Petrópolis:

Vozes, 1987.

FRYE, Northrop. Anatomia da crítica. Tradução de Péricles Eugênio da Silva Ramos. São Paulo: Cultrix, 1973.

GUMBRECHT, Hans U. Corpo e forma. Ensaios para uma crítica não-hermenêutica. Tradução de Marco Antonio Casanova. Rio de Janeiro: Eduerj, 1998.

HAMON, Philippe [et al.]. Categorias da narrativa. Tradução de Maria Alzira Seixo. Lisboa: Arcádia, 1976.

HANSEN, Adolfo. Alegoria. Construção e Interpretação da Metáfora. São Paulo: Atual, 1986.

HUTCHEON, Linda. Poética do Pós-Modernismo: história, teoria, ficção. Tradução de Ricardo Cruz. Rio de Janeiro: Imago, 1991.

. Uma Teoria da Paródia - Ensinamentos das formas de arte do século XX. Tradução de Teresa Louro Perez. Lisboa: 70, 1985.

JAEGER, Werner. Paidéia. A formação do homem grego. Tradução de Artur M. Parreira. São Paulo: Martins Fontes, 1995.

JAUSS, Hans Robert. et al. A literatura e o leitor - Textos de estética da recepção. Tradução de Luiz Costa Lima. 2.ed. Rio de Janeiro: Paz e Terra, 1979.

JUNG, C. G. Tipos psicológicos. Tradução de Álvaro Cabral. Rio de Janeiro: Zahar, 1967.

KAISER, W. Análise e interpretação da obra literária. Tradução de Paulo Quintela. Coimbra: Armênio Amado, 1958.

KAPLAN, E. Ann. (Org.) O Mal-estar no Pós-modernismo. Teorias, práticas. Tradução de Vera Ribeiro. São Paulo: Jorge Zahar, 1993. 
KURY, Adriano. Dicionário de Mitologia Grega e Romana. Rio de Janeiro, Zahar,1998.

LAING, Ronald D. "Identidade complementar" in: $O$ Eu e os Outros - O relacionamento interpessoal. Tradução de Áurea B. Weissenberg. Petrópolis: Vozes, 1986.

LEÃO, Lúcia. A estética do labirinto. São Paulo: Anhembi-Morumbi, 2002.

LYOTARD, Jean François. A condição pós-moderna. Tradução de J.B. de Miranda. Lisboa: Gradiva, 1989.

LOURENÇO, Eduardo. O labirinto da saudade. Lisboa: Dom Quixote, 1992.

LUBBOCK, Percy. A técnica da ficção. Tradução de Octávio Mendes Cajado. São Paulo: Cultrix-Edusp, 1976.

LUKÁCS, G. Teoria do romance: um ensaio histórico-filosófico sobre as formas da grande épica. Tradução de José Marcos de Macedo. São Paulo: Duas Cidades/ 34, 2000 .

MACHADO, Irene A. O romance e a voz: a prosaica dialógica de M. Bakhtin. Rio de Janeiro: Imago, São Paulo: FAPESP, 1995.

MAN, Paul de. Alegorias da leitura. Tradução de Lenita R. Esteves. Rio de Janeiro: Imago, 1996.

MARTINS, Oliveira. Portugal Contemporâneo. Lisboa: Publicações EuropaAmérica, s/d.

MEDINA, Cremilda de Araújo. Viagem à literatura portuguesa contemporânea. Rio de Janeiro: Nórdica, 1983.

MELLO e SOUZA, Antônio Candido de. Literatura e Sociedade. São Paulo: T.A. Queiroz, Publifolha, 2000.

. A personagem da ficção. São Paulo: Perspectiva, 1995. 
MOISÉS, Massaud. A criação Literária. 5.ed. São Paulo: Melhoramentos, 1973.

. Literatura, Mundo e Forma. São Paulo: Cultrix, 1982.

. Dicionário de termos literários. 3.ed. São Paulo: Cultrix, 1982.

MOTTA, Fernando C. Prestes e PEREIRA, Luiz Carlos B. Introdução à organização burocrática. 6.ed. São Paulo: Brasiliense, 1998.

MUIR, Edwin. A Estrutura do romance. Tradução de Maria da Glória Bordini. Rio de Janeiro: Globo, s/d.

OLIVIER, Reboul. Introdução à retórica. Tradução de Ivone Castilho Benedetti. São Paulo: Martins Fontes, 1998.

ORLANDI, Eni Puccinelli. A linguagem e seu funcionamento. As formas do discurso. São Paulo: Pontes, 1987.

. (Org.). Palavra, fé, poder. Campinas, SP: Fontes, 1987.

PAZ, Octávio. Signos em rotação. Tradução de Sebastião Uchoa Leite. São Paulo: Perspectiva, 1996.

PERRONE - MOISÉS. Altas Literaturas. São Paulo: Companhia das Letras, 1998.

PROENÇA FILHO, Domício. A linguagem Literária. São Paulo: Ática, 2001. Pós-modernismo e literatura. São Paulo: Ática, 1988.

PROPP, Vladimir I. Morfologia do conto maravilhoso. Tradução Jasna P. Sarhan. Rio de Janeiro: Forense Universitária, 1984.

REIS, Carlos. Técnicas de análise textual. Coimbra: Almedina, 1981.

ROSENFELD, A. "Reflexões sobre o romance moderno" In Texto/Contexto. São Paulo: Perspectiva, 1976. 
ROSENTAL. Ewim T. O universo fragmentário. Tradução de Marion Flischer. São Paulo: Companhia Editora Nacional, Edusp, 1975.

SANT'ANNA, Affonso Romano de. Paródia, paráfrase e Cia. 5.ed. São Paulo: Ática, 1995.

SEGOLIN, Fernando. Personagem e anti-personagem. 2.ed. São Paulo: Olho d'água, 1999.

STAM, Robert. Bakhtin - Da teoria literária à cultura de massa. Tradução de Heloísa Jahn. São Paulo: Ática, 1992.

TACCA, Óscar. As vozes do romance. Tradução de Margarida Coutinho Gouveia. Coimbra: Almedina, 1983.

TEIXEIRA, César M. Narração, dialogismo e carnavalização. 2006. Tese de Doutorado. Faculdade de Filosofia, Letras e Ciências Humanas, Universidade de São Paulo, São Paulo.

TODOROV, Tzvetan. Introdução à literatura fantástica. Tradução de Maria Clara C. Castello. São Paulo: Perspectiva, 1975.

WEBER, Max. Os fundamentos da organização burocrática: uma construção do tipo ideal. In CAMPOS, Edmundo (org.). Sociologia da burocracia. 4.ed. Rio de Janeiro: Zahar, 1978. p. 15-28.

WELLEK, R.; WARREN. A. Teoria da literatura. Tradução de José Palla e Carmo. 3.ed. Lisboa: Europa-América, 1971.

VARGA, A. Kibédi. Teoria Literária. Tradução Tereza Coelho. Lisboa: Presença, 1981.

VASCONCELOS, Montgomery José de. A poética carnavalizada de Augusto dos Anjos. São Paulo: Annablume, 1996. 